This document is the accepted manuscript version of the following article: Večeřa, M., Divíšek, J., Lenoir, J., Jiménez-A1faro, B., Biurrun, I., Knol1ová, I., ... Chytrý, M. (2019). Alpha diversity of vascular plants in European forests. Journal of Biogeography, 46(9), 1919-1935. https://doi.org/10.1111/jbi.13624

\title{
Alpha diversity of vascular plants in European forests
}

Running title: Alpha diversity in European forests

\author{
Martin Večeřa ${ }^{1 *}$, Jan Divíšek ${ }^{1,2}$, Jonathan Lenoir ${ }^{3}$, Borja Jiménez-Alfaro ${ }^{4}$, Idoia Biurrun ${ }^{5}$, Ilona \\ Knollová ${ }^{1}$, Emiliano Agrillo ${ }^{6}$, Juan Antonio Campos 5 , Andraž Čarni ${ }^{7}$, Guillermo Crespo Jiménez ${ }^{8}$, \\ Mirjana Ćuk ${ }^{9}$, Panayotis Dimopoulos ${ }^{10}$, Jörg Ewald ${ }^{11}$, Federico Fernández-González ${ }^{8}$, Jean-Claude \\ Gégout $^{12}$, Adrian Indreica ${ }^{13}$, Ute Jandt ${ }^{14,15}$, Florian Jansen ${ }^{16}$, Zygmunt Kącki ${ }^{17}$, Valerijus \\ Rašomavičius $^{18}$, Marcela Řezníčková ${ }^{1}$, John S. Rodwell19, Joop H. J. Schaminée ${ }^{20}$, Urban Šilc ${ }^{7}$, Jens- \\ Christian Svenning ${ }^{21,22}$, Grzegorz Swacha ${ }^{17}$, Kiril Vassilev ${ }^{23}$, Roberto Venanzoni24, Wolfgang \\ Willner ${ }^{25,26}$, Thomas Wohlgemuth ${ }^{27} \&$ Milan Chytrý $^{1}$ \\ * Corresponding author: martinvec@seznam.cz \\ ${ }^{1}$ Department of Botany and Zoology, Masaryk University, Brno, Czech Republic \\ 2 Department of Geography, Masaryk University, Brno, Czech Republic \\ ${ }^{3}$ UR 'Ecologie et Dynamique des Systèmes Anthropisés' (EDYSAN, UMR 7058 CNRS-UPJV), Jules Verne University of \\ Picardie, Amiens, France \\ ${ }^{4}$ Research Unit of Biodiversity (CSIC/UO/PA), University of Oviedo, Mieres, Asturias, Spain \\ ${ }^{5}$ Department of Plant Biology and Ecology, University of the Basque Country UPV/EHU, Bilbao, Spain \\ ${ }^{6}$ Department of Environmental Biology, Sapienza University of Rome, Rome, Italy \\ ${ }^{7}$ Jovan Hadži Institute of Biology, Research Centre of the Slovenian Academy of Sciences and Arts, Ljubljana, Slovenia \\ ${ }^{8}$ Institute of Environmental Sciences, University of Castilla-La Mancha, Toledo, Spain \\ ${ }^{9}$ Department of Biology and Ecology, University of Novi Sad, Novi Sad, Serbia \\ ${ }^{10}$ Department of Biology, Laboratory of Botany, University of Patras, Patras, Greece \\ ${ }^{11}$ Faculty of Forestry, Weihenstephan-Triesdorf University of Applied Sciences, Freising, Germany \\ 12 Université de Lorraine, AgroParisTech, INRA, Silva, Nancy, France \\ ${ }^{13}$ Department of Silviculture, Transilvania University of Brașov, Brașov, Romania \\ ${ }^{14}$ Department of Geobotany and Botanical Garden, Martin Luther University Halle-Wittenberg, Halle, Germany \\ ${ }^{15}$ German Centre for Integrative Biodiversity Research (iDiv) Halle-Jena-Leipzig, Leipzig, Germany \\ ${ }^{16}$ Faculty of Agricultural and Environmental Sciences, University of Rostock, Rostock, Germany \\ ${ }^{17}$ Botanical Garden, University of Wrocław, Wrocław, Poland \\ ${ }^{18}$ Laboratory of Flora and Geobotany, Institute of Botany, Nature Research Centre, Vilnius, Lithuania \\ ${ }^{19}$ Lancaster, UK \\ ${ }^{20}$ Wageningen Environmental Research, Wageningen, the Netherlands \\ ${ }^{21}$ Center for Biodiversity Dynamics in a Changing World, Department of Bioscience, Aarhus University, Aarhus, Denmark \\ ${ }^{22}$ Section for Ecoinformatics and Biodiversity, Department of Bioscience, Aarhus University, Aarhus, Denmark \\ ${ }^{23}$ Institute of Biodiversity and Ecosystem Research, Bulgarian Academy of Sciences, Sofia, Bulgaria \\ ${ }^{24}$ Department of Chemistry, Biology and Biotechnology, University of Perugia, Perugia, Italy \\ ${ }^{25}$ Department of Botany and Biodiversity Research, University of Vienna, Vienna, Austria \\ ${ }^{26}$ Vienna Institute for Nature Conservation and Analyses, Vienna, Austria \\ ${ }^{27}$ Forest Dynamics Research Unit, Swiss Federal Institute for Forest, Snow and Landscape Research WSL, Birmensdorf, \\ Switzerland
}




\begin{abstract}
Aim

The former continental-scale studies modelled coarse-grained plant species-richness patterns (gamma diversity). Here we aim to refine this information for European forests by (i) modelling the number of vascular plant species that co-occur in local communities (alpha diversity) within spatial units of 400 $\mathrm{m}^{2}$; and (ii) assessing the factors likely determining the observed spatial patterns in alpha diversity.
\end{abstract}

\title{
Location
}

Europe roughly within $12^{\circ} \mathrm{W}-30^{\circ} \mathrm{E}$ and $35-60^{\circ} \mathrm{N}$.

\section{Taxon}

Vascular plants.

\section{Methods}

The numbers of co-occurring vascular plant species were counted in 73,134 georeferenced vegetation plots. Each plot was classified by an expert system into deciduous broadleaf, coniferous, or 
sclerophyllous forest. Random Forest models were used to map and explain spatial patterns in alpha diversity for each forest type separately using 19 environmental, land-use, and historical variables.

\section{Results}

Our models explained from 51.0 to $70.9 \%$ of the variation in forest alpha diversity. The modelled alphadiversity pattern was dominated by a marked gradient from species-poor North-western to species-rich South-eastern Europe. The most prominent richness hotspots were identified in the Calcareous Alps and adjacent north-western Dinarides, the Carpathian foothills in Romania, and the Western Carpathians in Slovakia. Energy-related factors, bedrock types, and terrain ruggedness were identified as the main variables underlying the observed richness patterns. Alpha diversity increases especially with temperature seasonality in deciduous broadleaf forests, on limestone bedrock in coniferous forests, and in areas with low annual actual evapotranspiration in sclerophyllous forests.

\section{Main conclusions}

We provide the first predictive maps and analyses of environmental factors driving the alpha diversity of vascular plants across European forests. Such information is important for the general understanding of European biodiversity. This study also demonstrates a high potential of vegetation-plot databases as sources for robust estimation of the number of vascular plant species that co-occur at fine spatial grains across large areas.

\section{Keywords}

Diversity, Europe, European Vegetation Archive (EVA), Forest vegetation, Plant community, Predictive modelling, Random Forests, Species-richness patterns, Vascular plants, Vegetation-plot database

\section{Introduction}

Describing and understanding patterns of plant species richness have been among the overarching goals of biogeography since its beginnings. Even now, plant diversity remains one of the key topics of community ecology and macroecology, as it summarizes the outcome of many ecosystem processes (Grace, 1999). New incentives for studying plant diversity patterns have arisen in recent decades in the face of rapid human-induced environmental changes and subsequent biodiversity losses at the global scale (e.g., Pereira et al., 2010). Given the fact that plants contribute, by far, the largest proportion of terrestrial biomass on Earth (Bar-On, Phillips, \& Milo, 2018), understanding fine-grain plant diversity patterns across large spatial extents and their drivers is of primary interest in both science and conservation practice.

Vascular plant diversity has been explored and mapped in numerous studies performed all around the world. It has been addressed in various geographical and environmental settings ranging from (i) regional extents (e.g., Albuquerque, Olalla-Tárraga, Montoya, \& Rodríguez, 2011; Divíšek \& Chytrý, 2018; Wohlgemuth, 1998), sometimes focused on specific biomes (e.g., Crespo-Mendes, Laurent, Bruun, \& Hauschild, 2019); (ii) through continental extents (e.g., Araújo, Thuiller, Williams, \& 
Reginster, 2005; Lahti \& Lampinen, 1999; Ronk, Szava-Kovats, \& Pärtel, 2015); (iii) up to the global extent (e.g., Barthlott et al., 2007; Kreft \& Jetz, 2007; Wulff, 1935). Despite considerable progress in mapping plant species-richness patterns across large areas during the past decades (Barthlott et al., 2007; Kier et al., 2005; Kreft \& Jetz, 2007; Ulloa Ulloa et al., 2017), most studies to date have focused on vascular plant species richness assessed at coarse spatial resolutions, using data from grid atlases (e.g., Araújo et al., 2005), expert-drawn range maps (e.g., Currie \& Paquin, 1987), or floras and regional checklists (e.g., Ulloa Ulloa et al., 2017). Such studies described the whole diversity of relatively large areas, i.e., gamma diversity (Whittaker, 1972). If such studies analysed factors affecting plant species richness across broad spatial extents (e.g., Francis \& Currie, 2003; Kreft \& Jetz, 2007; Qian, White, \& Song, 2007), they have mostly focused on the role of large-scale environmental drivers, especially current climate (Hawkins et al., 2003). Very few studies have considered factors related to habitat heterogeneity and environmental history and combined them into a single model of species richness (e.g., Jiménez-Alfaro et al., 2018).

Despite the wealth of knowledge on vascular plants as a taxonomic group, we still lack information on the global or continental distribution of their species richness at fine spatial resolution (Beck et al., 2012), also known as alpha diversity (Whittaker, 1972), i.e., the grain at which plant species potentially interact. This stems from the fact that continental and global vegetation-plot databases had been missing until very recently (Bruelheide et al., 2019; Chytrý et al., 2016). Yet, only vegetation-plot data providing complete lists of species co-occurring locally can be used to model the spatial distribution of alpha diversity and to understand its determinants. This kind of data contains relatively precise information on species richness at georeferenced sites (Chytrý et al., 2016) as well as information on species composition that makes it possible to differentiate vegetation types. By producing maps of vascular plant species richness at the level of individual plots $\left(16\right.$ and $400 \mathrm{~m}^{2}$ for grasslands and forests, respectively), Divíšek \& Chytrý (2018) demonstrated that vegetation-plot databases are a valuable source of data for high-resolution mapping of plant species richness of different vegetation types and species groups because each of them can exhibit a different diversity pattern. This and other recent studies (Jiménez-Alfaro et al., 2018; Lenoir et al., 2010) also showed that considering just one habitat type in a broad spatial extent may provide essential insights into the driving mechanisms of species richness, often related to ecology and history of a specific habitat.

Here, we focus on the alpha diversity of forest vegetation across a large part of the European continent at the level of all forest types together, and three main forest types separately - deciduous broadleaf, coniferous, and sclerophyllous. These forest types correspond to the main functional groups of European trees, which are driven by different biogeographical histories and ecological requirements (e.g., Barbero, Loisel, \& Quézel, 1992; Bohn et al., 2003; Tzedakis, Emerson, \& Hewitt, 2013). Thus we expect potential differences in their alpha-diversity patterns and related explanatory factors. Forests represent a major component of Europe's terrestrial ecosystems (Bengtsson, Nilsson, Franc, \& Menozzi, 2000). Therefore we hypothesize that their alpha diversity displays similar spatial pattern as that 
documented by previous maps of plant gamma diversity (e.g., Kreft \& Jetz, 2007), i.e., the gradient from the species-poor north to the species-rich south of the continent. The highest gamma diversity, as well as the largest site-specific species pools of vascular plants in Europe, can be found in mountainous areas in the southern and central parts of the continent (Araújo et al., 2005; Ronk et al. 2015). It is these areas where we expect also the location of the highest alpha diversity in European forests (hereafter referred to as 'richness hotspots').

North-south gradients in species richness may result partly from current climate conditions. It is generally believed that species-richness patterns at extratropical latitudes with relatively cooler climates can be explained by water-energy interactions, in which ambient heat is the main limiting factor for both plants and animals (Hawkins et al., 2003; Jiménez-Alfaro, Chytrý, Mucina, Grace, \& Rejmánek, 2016). Nevertheless, there are other factors operating on regional to local scale that can play an important role. Habitat heterogeneity, including land-cover composition, topography, and bedrock-chemistry gradients in the surroundings of local communities, influences the species-pool size for the focal habitat, mass effects, and dispersal limitation of specialized species (Divíšek \& Chytrý, 2018; Janišová, Michalcová, Bacaro, \& Ghisla, 2014). Further, environmental or biogeographical history, especially past climate, has been proposed as a strong factor controlling current richness patterns (e.g., Lenoir et al., 2010; Svenning, Normand, \& Skov, 2009). The European flora has undergone considerable changes in distribution ranges as well as massive diversity losses during the Pleistocene climatic oscillations, which left significant imprints in current floristic composition and richness patterns (Ewald, 2003; Svenning et al., 2009).

On a local scale, numerous environmental factors have been suggested to affect species richness of the herb layer in European forests, e.g., herb-layer productivity (e.g., Axmanová et al., 2012), light availability (e.g., Ewald, 2008), soil pH (e.g., Zerbe, Schmidt, \& Betzin, 2007), soil moisture (e.g., Härdtle, von Oheimb, \& Westphal, 2003), soil nutrients (e.g., Pausas, 1994), tree layer species composition (e.g., Kooijman \& Cammeraat, 2010), fine-scale terrain configuration, or forest management (e.g., Horvat, Biurrun, \& García-Mijangos, 2017). The effects of these factors on species richness are often interrelated, and their relative importance, as well as the direction of their effects, may vary among individual forest community types, groups of species, or regional environmental contexts (Axmanová et al., 2012; Härdtle et al., 2003). Given the absence of continent-wide data on such finescale, spatially highly variable factors, we cannot directly include them in the modelling procedure.

As the focus of our study is the pattern of alpha diversity across a continent, i.e., regional comparisons, we hypothesize that broad-scale environmental factors, particularly energy-related climatic variables, play the main role here. Past climate and other historical factors can also have influenced regional differences in alpha diversity. However, we also expect important effects of more fine-grained factors (e.g., topographical heterogeneity, bedrock chemistry, and land cover) on alphadiversity patterns. 
To examine these hypotheses, we followed a predictive modelling approach combining a large set of georeferenced vegetation plots covering most of the European forest types and spatial grids describing the current and past environment, including the factors operating both on the coarse and fine scale. The predictive modelling enabled us to join two perspectives on alpha-diversity patterns - mapping and understanding the drivers - in a single project. The aims of this paper are: (i) to map the expected number of vascular plant species which may co-occur locally within European deciduous broadleaf, coniferous, and sclerophyllous forests; and (ii) to identify drivers that might determine the observed spatial patterns in alpha diversity.

\section{Materials and methods}

\section{Study area}

Our study area spans from Portugal in the west to the European part of Turkey in the east, and from southern Scandinavia in the north to Sicily and Crete in the south. We omitted the territories of Russia, Belarus, Ukraine, Moldova, Iceland, Malta, Finland, and large parts of Norway and Sweden because of a low density of available forest vegetation plots with complete species records.

\section{Data on species richness}

Georeferenced vegetation-plot records were obtained mainly from the European Vegetation Archive (EVA; Chytrý et al., 2016; accessed on 18 January 2016), which integrates dozens of national and regional vegetation databases covering most of Europe and contains more than 1.5 million vegetation plots. For France, we additionally downloaded data from the French National Forest Inventory database (Robert et al., 2012; https://inventaire-forestier.ign.fr/) to improve the spatial coverage. To identify forest vegetation in the databases, we used an expert system for classification of European forests based on their species composition (Schaminée et al., 2014), run in the JUICE program (Tichý, 2002). We selected those plots which were classified by this expert system into forest habitat types according to the modified EUNIS classification as used in the project of the European Red List of Habitats (Janssen et al., 2016). Subsequently we merged these forest types into three main types - deciduous broadleaf, coniferous, and sclerophyllous forests. We used plots with a surface area ranging between 100 and $1000 \mathrm{~m}^{2}$, which were the most common plot sizes used for sampling. We initially selected 93,484 forest plots. An overview of contributing databases and numbers of plots assigned to particular EUNIS forest habitat types is available in Appendix S1, Tables S1.1 and S1.2 in Supporting Information.

In each plot, we merged multiple records of the same species occurring in more than one vegetation layer (e.g., tree species occurring in the herb, shrub, and tree layers), removed non-vascular plants, and counted the number of species. If the sampling date was available ( $82.1 \%$ of plots), we removed plots older than 1970 (13.2\%) in order to avoid potential bias related to long-term vegetation changes. A common deficiency of vegetation-plot databases is that some plots are not accurately georeferenced, i.e., there is a certain spatial difference between the actual sampling site and geographical coordinates 
provided in the database (hereafter referred to as 'location uncertainty'). From the set of plots with information on location uncertainty (56.3\% of the remaining plots), we removed plots with an indicated uncertainty larger than $2821 \mathrm{~m}$ (i.e., the radius of a circular buffer zone of $25 \mathrm{~km}^{2}$ ) and plots georeferenced into grid cells of $10 \times 10 \mathrm{~km}$ or larger (altogether $7.7 \%$ ). By doing so, we reduced the spatial mismatch between data on species richness and data on environmental conditions extracted mostly from coarse-grain spatial grids. However, we retained plots with no information on location uncertainty because some countries were represented only by this sort of data. Generally, the information on location uncertainty was often not available in the database even for relatively recent plots presumably geo-referenced with GPS devices.

Based on the selection criteria and assignment of plots to certain forest types, we prepared four different datasets: (i) 'all forests' containing 73,134 plots (Figure 1); (ii) 'deciduous broadleaf forests' containing 54,521 plots; (iii) 'coniferous forests' containing 15,978 plots; and (iv) 'sclerophyllous forests' containing 2635 plots (Appendix S1, Figure S1.1).

\section{Environmental variables}

Predictor variables related to environmental and historical drivers of alpha-diversity patterns were extracted from vector maps and raster grids using ArcGIS (ESRI, 2011) and QGIS (QGIS Development Team, 2015). First, we delimited a circular buffer zone $\left(\sim 25 \mathrm{~km}^{2}\right)$ around each vegetation plot to calculate values of predictor variables that were then assigned to the respective plot. For quantitative variables (e.g., mean annual temperature), we calculated the mean value within the buffer zone. For categorical variables (e.g., area of forest), we calculated the proportion of the buffer zone area occupied by each (e.g., land-cover) category (Appendix S1, Figure S1.3). We used this approach because the coordinates of some vegetation plots are inaccurate and because environmental and historical data differ in terms of spatial resolution. The buffer approach smoothed potentially extreme values of environmental variables from point extractions and reduced potential spatial autocorrelation in model residuals. The area of circular buffers around each vegetation plot corresponds to the size of the UTM grid cells $(5 \times 5 \mathrm{~km})$ that we used for visualization of the predicted alpha-diversity values across the European continent.

The predictor variables can be divided into three broad groups: (i) current environment; (ii) environmental history; and (iii) land cover (Table 1). The first group is represented by factors related to topography, substrate (geology and soil), and climate. The second group contains variables related to glacial history and palaeoclimate. The third group contains proportions of aggregated land-cover types in the surroundings of each vegetation plot. A detailed description of the set of predictor variables used as well as correlation matrices of variables for all forests and for each particular forest type are provided in Appendix S1. In addition, we used plot size as a covariate in all of our models to account for the potential effect of plot size variation (i.e., species-area relationships). 


\section{Modelling and mapping alpha-diversity patterns}

We followed the procedure used by Divíšek \& Chytrý (2018) for modelling and mapping plant species richness at the local scale using the Random Forest algorithm (Breiman, 2001). This machine-learning method combining predictions of individual regression trees grown on a large number of bootstrap samples is considered very powerful for modelling complex relationships (Prasad, Iverson, \& Liaw, 2006) that exist between species richness and the underlying predictor variables. Details of model fitting are described in Appendix S1.

The 19 variables listed in Table 1 as well as plot size were used as predictors and their relative importance within the models was expressed by 'Mean decrease in accuracy' and 'Mean decrease in node impurity'. The former quantifies non-randomness of the effect of the particular predictor in the model, while the latter quantifies the predictive power of the predictor (see Appendix S1 for details on these measures). In order to consider both aspects of predictor importance, we rescaled both the measures to values ranging from 0 to 1 and calculated their average. Thus, we obtained a single measure of 'integrated' relative importance.

The models were calculated using the $\mathrm{R}$ software (version 3.2.5; R Core Team, 2016) with the 'randomForest' package (Liaw \& Wiener, 2002). Relationships between species richness and individual predictors were visualized using partial dependence plots (Hastie, Tibshirani, \& Friedman, 2009), which depict the effect of a given predictor on species richness while averaging effects of the other predictors in the model. Spatial autocorrelation in residuals of each model was checked using spatial correlograms showing Moran's I statistics for distance classes defined using Sturges' rule. As we were interested in spatial autocorrelation at short spatial distances, we randomly placed 500 rectangular windows (with a side length of $200 \mathrm{~km}$ ) across sampled regions within the study area and calculated a spatial correlogram for a subset of plots in each of these windows. Resulting correlograms (i.e., Moran's $I$ values corresponding to distance classes defined in each window) were then summarized using local polynomial regression fitting with a span of 0.75 .

Alpha-diversity values were predicted using the Random Forest models, based on the values of environmental variables calculated within UTM grid cells of $5 \times 5 \mathrm{~km}$, i.e., the same area as that of the circular buffer zones used to assign values of environmental variables to vegetation plots. The inclusion of plot size to the models enabled us to set a fixed plot size of $400 \mathrm{~m}^{2}$ for the model predictions. This plot size was the one most frequently occurring in our dataset. Thus the predicted alpha diversity is the number of species expected to be found in a plot of $400 \mathrm{~m}^{2}$ in a respective forest type within a given UTM grid cell of $5 \times 5 \mathrm{~km}$, which was used to visualize the predicted alpha-diversity value on maps. The cell size of $5 \times 5 \mathrm{~km}$ used for visualization of our results was selected as a compromise between sufficiently high resolution and low computational demands. However, we also provide zoomed windows with the predicted alpha diversity for all forests visualized at a finer spatial resolution of $1 \times 1 \mathrm{~km}$, based on values of environmental variables calculated within UTM grid cells of this size (Appendix S2, Figure S2.8). 
Richness hotspots and the top hotspots within them were identified as grid cells with predicted alpha-diversity values in or above the $95^{\text {th }}$ percentile (Prendergast, Quinn, Lawton, Eversham, \& Gibbons, 1993) and the $99^{\text {th }}$ percentile, respectively.

To estimate the uncertainty of the predicted alpha diversity, we calculated and mapped standard deviation of predictions of individual regression trees $(n=500)$ within each Random Forest model. We also checked the spatial distribution of grid cells whose environmental conditions are out of range of conditions covered by the vegetation-plot data, to find out areas where the models are extrapolating in terms of environment.

\section{Stability of the predicted alpha-diversity patterns}

Vegetation-plot data were originally collected by botanists, foresters, nature conservationists, and people from related fields for various purposes (Divíšek \& Chytrý, 2018). This implies several peculiarities of such kind of data, two of which are especially relevant for modelling species-richness patterns. First, it is an uneven sampling effort (Knollová, Chytrý, Tichý, \& Hájek, 2005), with large variability in spatial coverage and density of vegetation-plot records across Europe in our data. Some regions are undersampled, while in others, plots tend to be spatially clustered. This implies a risk of bias in model results. A specific case of clustering is that groups of several plots share the same geographical coordinates (35.7\% of the plots used). These groups originate from repeated surveys over time (i.e., time series from permanent or quasi-permanent plots) or from surveys of small areas, e.g., nature reserves, in which all individual plots were assigned the same geographical coordinates. The second important issue is preferential sampling, which is traditionally applied within vegetation surveys following the European phytosociological school (Westhoff \& van der Maarel, 1978). Preferential sampling may result in species-rich communities being sampled more evenly across a study area than species-poor communities (Chytrý, 2001), thus again potentially introducing a bias to estimates of species richness.

To test whether the predicted patterns of alpha diversity might be affected by these issues, we applied three different resampling strategies (following Divíšek \& Chytrý, 2018) and compared the resulting models with the model based on the original dataset. The first strategy preferred plots from undersampled regions: We calculated the density of plots across the study area using the Kernel Density tool in ArcGIS and assigned a density value to each plot. Then we applied weighted random sampling to create a subset containing two-thirds of plots from the original dataset with a preference of plots from the poorly sampled regions. The other two strategies reduced local oversampling using criteria of spatial distance among plots and their similarity in species composition: If two plots were sampled close to each other and they were, at the same time, similar in species composition, then just one plot from such a pair was selected (see Appendix S1 for a detailed description of the algorithm). We did two variants of this resampling: (i) selecting the richer plot, and (ii) selecting a random plot from each pair. The former approach reflected the assumption that species-rich plots might cover the study area more 


\section{Results}

The Random Forest models explained between $51.0 \%$ and $70.9 \%$ of the variation in alpha diversity (Table 2), with the best fit achieved for coniferous forests. Moran's $I$ values at the $1^{\text {st }}$ lag distance were negative and close to zero for all the considered forest types, indicating no obvious spatial patterns in the residuals (Appendix S2, Figures S2.9-S2.12).

We detected a marked geographical gradient in vascular plant alpha diversity from relatively species-poor forests in North-western Europe to relatively species-rich forests in South-eastern Europe (Figure 2a), i.e., from oceanic lowlands to more continental mountainous and hilly areas. The most prominent top richness hotspots of all forests (on average $47 \pm 4$ species predicted to co-occur within a $400-\mathrm{m}^{2}$ plot) were modelled for both the Northern and Southern Calcareous Alps and adjacent northwestern Dinarides, the Carpathian foothills in Romania, and the Western Carpathians (Figure 2b). Alpha-diversity patterns were similar for both deciduous broadleaf and coniferous forests, with speciesrich areas concentrated mostly in Central and South-eastern Europe (Figure 2c, d). The top richness hotspots for deciduous broadleaf forests (on average $45 \pm 4$ species) were more scattered, including mostly lower parts of mountain ranges from the western Pyrenees to the Carpathian foothills in Romania, but also lowland forests of the hemiboreal zone in Lithuania (Appendix S2, Figure S2.13a). For coniferous forests, the top richness hotspots (on average $48 \pm 3$ species) were limited to mountainous areas, especially to the Calcareous Alps, north-western Dinarides, and Western Carpathians (Appendix S2, Figure S2.13b). In sclerophyllous forests, high alpha diversity is predicted mainly in southern parts of the three Southern European peninsulas (Figure 2e), with the top richness hotspots (on average $43 \pm$ 4 species) in the eastern-central Iberian Peninsula, the central parts of Sicily, the Peloponnese, and along the Ionian coast of Greece (Appendix S2, Figure S2.13c).

Predictors contributing the most to the total explained variation in all forests were temperature seasonality, the proportion of limestone bedrock, and the proportion of forest areas (Figures 3a and 4a). In deciduous broadleaf forests, the most important predictors were temperature seasonality, annual precipitation, and the proportion of forest area (Figure 3b). High alpha diversity was related to higher values of both the climatic variables, while the proportion of forest area showed no obvious trend with 
only slightly higher alpha diversity related to less forested landscapes (Figure $4 b$ ). In coniferous forests, alpha diversity was best explained by the proportion of limestone bedrock, terrain ruggedness, and temperature seasonality (Figure 3c). All the predictors showed a positive effect here, with high alpha diversity related to medium to high proportions of limestone bedrock, more rugged terrains, and higher values of temperature seasonality (Figure 4c). In sclerophyllous forests, alpha diversity responded primarily to climatic variables (Figure 3d), being high particularly in areas with low annual actual evapotranspiration, low annual precipitation, and high annual potential evapotranspiration (Figure 4d). The effects of the lower-ranked predictors on alpha diversity are summarized in Appendix S2, Figures S2.15-S2.18.

The mean prediction uncertainty of all the models, measured as the standard deviation of predictions of individual regression trees, was \pm 12 species. Higher uncertainties were found generally in species-rich areas such as the Western Alps and in some areas with deficient data, e.g., the northern part of the Romanian Carpathians (Appendix S2, Figure S2.19). The range of environmental conditions covered by the input vegetation-plot data was well captured within almost the whole study area (Appendix S2, Figure S2.20). Relatively larger areas where values of one predictor variable are out of the range covered by the vegetation-plot data were found only in small parts of Sweden, the Baltic countries, and Poland. In these cases, there were higher values of temperature change since the Last Glacial Maximum (LGM) and current temperature seasonality than covered by the plot data.

In all cases, the models based on different resampling strategies predicted almost the same patterns of alpha diversity of all forests as the model based on the original non-resampled dataset (Spearman's correlation coefficient between models ranged from 0.96 to 0.98 ). The latter model had a slightly better fit to the data ( $56 \%$ of explained variation) than the models based on resampling (47-51\%). There was a negligible slightly negative spatial autocorrelation in residuals from all the models (see Tests of stability of the predicted alpha-diversity patterns in Appendix S2). These results indicate that the predicted alpha-diversity patterns are very robust, not depending on whether a resampling procedure is applied or not.

\section{Discussion}

\section{Modelling and mapping alpha diversity across European forests}

Based on a set of predictors capturing current environmental conditions and land cover as well as past climate changes, the proportion of the variation in vascular plant alpha diversity of European forests explained in our models was on average $59.5 \%$. Other recent studies using vegetation plot data to model species-richness patterns in forest communities explained 47\% (for all forests in the Czech Republic; Divíšek \& Chytrý, 2018) and 31\% of the variation (for European beech forests; Jiménez-Alfaro et al., 2018), respectively. However, these comparisons have to be taken with caution, as the amount of explained variation is always somehow influenced by the modelling algorithm and the number of predictor variables used. 
We provide the first maps of the number of vascular plant species expected to co-occur locally (i.e., alpha diversity) for the major forest types across a considerable part of the European continent. We reveal broad-scale patterns in alpha diversity that are somewhat similar to former work depicting European plant species-richness patterns at a much coarser grain (i.e., gamma diversity; Araújo et al., 2005; Lahti \& Lampinen, 1999; Ronk et al., 2015; Svenning et al., 2009), with a spatial gradient ranging from relatively species-poor oceanic lowlands of North-western Europe to relatively species-rich continental and mountainous areas of South-eastern Europe. This similarity between alpha diversity of European forests and gamma diversity of the whole flora might be a result of the species-pool effect (e.g., Cornell \& Harrison, 2014), assuming that gamma diversity well reflects the species-pool sizes of forest habitats. However, the congruence between gamma diversity and species pool may strongly vary region by region, and not even a significant correlation between the size of the species pool and richness per unit area necessarily demonstrates the effect of species pool on the richness of local communities (Herben, 2000). Nevertheless, such a comparison was not the purpose of this study.

Although we found forest richness hotspots mainly in Central and South-eastern European mountain ranges, thus supporting former findings from the studies of gamma diversity, our maps also suggest important and 'unexpected' richness hotspots in Eastern Europe, within the lowland forests of the hemiboreal zone in Lithuania, as well as along the Carpathian foothills in Romania. This trend is consistent with the observation of very high forest species richness in continental areas within the foreststeppe zone (Chytrý et al., 2012). We suggest that these continental areas should receive more attention from both the scientific and nature conservation perspectives in the pan-European context.

Species-richness patterns across large spatial extents have been traditionally understood as a function of the current environment and especially climate conditions (e.g., Currie \& Paquin, 1987; Francis \& Currie, 2003). This is valid also for alpha diversity of vascular plants in European forests. Although the three forest types differ in the proposed main driving mechanisms of alpha diversity, energy-related climatic factors are among the three most important predictors of each of the types (Figure 3). The importance of habitat heterogeneity and landscape context for fine-grained speciesrichness patterns (Divíšek \& Chytrý, 2018; Janišová et al., 2014) was also corroborated by high ranking of limestone bedrock, terrain ruggedness, and land cover of the surrounding landscape such as proportions of forest area and mosaic land area with non-forest semi-natural habitats. The past climate has been documented to influence especially gamma diversity (e.g., Svenning et al., 2009), while its effects on alpha-diversity patterns are less obvious (Lenoir et al., 2010). We accounted for such historical effects by including predictor variables related to (i) climate change (e.g., Sandel et al., 2011), assuming that more stable climatic conditions between the late Pleistocene and Holocene may have favoured refugial effects, and thus higher species richness; and (ii) LGM glaciation, assuming that current forest communities existing in the areas recolonized after deglaciation are poor in species due to dispersal lag (e.g., Svenning \& Skov, 2004). The climate change predictors (temperature and precipitation change since the LGM) were ranked relatively high in the case of coniferous and deciduous broadleaf forests. 
However, the presence of LGM glaciers had the lowest ranking in our models (Figure 3), suggesting that this predictor was not able to capture the potentially significant role of postglacial dispersal from refugia of forest alpha diversity. Since the only refugia of forest species in Europe with relatively wellknown locations are those of beech forests (Magri, 2008), developing a predictor of forest species richness accounting for postglacial dispersal events remains a challenge for further research (JiménezAlfaro et al., 2018).

The proportion of unexplained variation in the data may be attributed to local-scale environmental conditions (e.g., Axmanová et al., 2012; Ewald, 2008), forest management (e.g., Horvat et al., 2017), and historical factors not accounted for by our predictor variables, as suggested by the negative (although negligible) spatial autocorrelation in the model residuals (Table 2). A crucial point here may be the role of forest management and its history, as it largely influences local-scale environmental conditions, especially the availability of light. Almost all forests in Europe (>99\%) are subject to some kind of management (Parviainen, 2005), and the management intensity is highly variable in space and time. Only the most intensive management practices (particularly clear-cutting and changes in tree species composition) have been proven to have a significant negative effect on vascular plant species richness (Paillet et al., 2010). In contrast, low-intensity or 'traditional' forest management practices such as coppicing can promote species richness (e.g., Hédl, Kopecký, \& Komárek, 2010). The vegetation-plot data we used come mostly from botanical (phytosociological) field surveys that traditionally focus on forests with near-natural species composition, therefore they should not be markedly affected by intensive forest management. We rather suppose that locally positive effects of management on alpha diversity may be reflected in our results. For instance, in some of the predicted richness hotspots, lowintensity management practices such as forest grazing (e.g., in the Alps or Jura Mountains; Ewald, 2000; Peringer et al., 2013), selective logging (e.g., in Slovenia; Veselič et al., 2008), or coppicing in the past (e.g., along the Carpathian foothills in Romania and in Poland; Szymura, 2012) are supposed to support or maintain high species richness. These traditional practices are also known to favour an open forest structure (e.g., Decoq et al., 2004), creating benign conditions for forest specialists in shady patches as well as canopy openings suitable for more light-demanding and generalist species coming from the surrounding landscape. Our data did not directly include such drivers, even though we used proxies potentially capturing some of their local variation (e.g., Jiménez-Alfaro et al., 2018). Nevertheless, nonmeasured variables and stochastic processes such as patch dynamics and spatial mass effects may play a role in shaping spatial patterns in alpha diversity.

\section{Deciduous broadleafforests}

Our results suggest a strong relationship between the alpha diversity of deciduous broadleaf forests and energy-related variables such as temperature seasonality and annual precipitation. High alpha diversity in deciduous broadleaf forests is predicted in areas with pronounced temperature seasonality, i.e., more 
continental climates, and also in more oceanic precipitation-rich areas. These patterns may be considered from the perspective of two different spatial scales: (i) the continental scale, and (ii) the regional scale.

On the continental scale, these two climatic modes generally do not overlap, and the richness hotspots associated with them thus require more or less separate explanations. In more continental areas, alpha diversity can be positively affected by relatively high energy inputs during the warm and long growing seasons. This may apply to both deciduous broadleaf and coniferous forests. In addition, there can be indirect effects of pronounced temperature seasonality - in particular, the existence of foreststeppe in more continental areas of South-eastern Europe enables mixing of forest and light-demanding species. The high alpha diversity of deciduous broadleaf forests in precipitation-rich areas on the panEuropean scale is found especially along the mountain fringes, where rainfall, large areas of forests, and high topographical heterogeneity coincide, e.g., in the Western Alps, Southern Calcareous Alps, and northern Dinarides. The adjacent areas in the southeast and southwest are considered to have served as refugia of some forest species during the Pleistocene glaciations (Magri, 2008; Tzedakis et al., 2013). Postglacial migration from the nearby refugia has been suggested to be among the key factors shaping current high species richness of beech forests in the Alps (Jiménez-Alfaro et al., 2018; Ujházyová et al., 2016). The survival of forest species in the refugia may have been facilitated, among other factors, by relatively humid conditions due to orographic precipitation. From this point of view, current high precipitation may not have a direct effect on current species richness in that area, but it may correlate with relatively high precipitation in the full glacial, which may have been crucial.

On the regional scale, locally specific combinations of precipitation and temperature seasonality may occur. It has been shown that slightly higher continentality in a relatively precipitation-rich area or slightly higher precipitation in a relatively continental area may cause locally or regionally increased species richness (e.g., Horvat et al., 2017; Wohlgemuth, 1998). This may be, for instance, the case of high forest alpha diversity in some areas of the western Balkan Peninsula.

A low proportion of forest area in the surroundings of the sampled site is related to slightly higher alpha diversity for deciduous broadleaf forests, however, the trend is not very pronounced (Figure $4 b$ ). The same equivocal pattern was found by Divišsek \& Chytrý (2018) at a regional scale within Czech forests. This can likely be attributed to two contrasting tendencies, both affecting forest species richness via enlarging/maintaining species pools: (i) spatial mass effects resulting from habitat heterogeneity in the landscapes with smaller forest areas, more ecotones, and consequently an even higher chance for generalist species to occur in a forest; and (ii) within-forest habitat heterogeneity, connectivity, longterm continuity and stability of forest environments in more forested landscapes (Honnay et al., 2002).

\section{Coniferous forests}

All the top richness hotspots for coniferous forests are in areas dominated by limestone or other calcareous bedrocks. This pattern is likely related to the evolutionary and glacial history of Central Europe. Existing systems of indicator values suggest that a vast majority of Central European vascular 
plant species prefer base-rich and calcareous soils (e.g., Ellenberg et al., 1991), which is also valid for the forest flora (Ewald, 2003; Ujházyová et al., 2016). A positive relationship between species richness and soil $\mathrm{pH}$ may be mediated through species-pool effects, namely the legacy of selection towards a base-rich flora within biogeographical regions dominated by calcareous bedrocks (Ewald, 2003; Pärtel, 2002).

Montane coniferous forests, often growing on shallow soil and in rugged terrain, tend to have a relatively sparse canopy which enables occurrence of light-demanding species with an optimum in nonforest vegetation. This is true for both calcareous and non-calcareous soils, but the species pool on calcareous bedrock is much larger. Another factor increasing local species richness of montane coniferous forests on limestones is an admixture of acidophilous species in local patches of acid forest floor arising from poorly decomposed needle litter and old deadwood structures, particularly at higher elevations (Ewald, 2008; Ujházyová et al., 2016).

Terrain ruggedness was the second most important driver of alpha-diversity patterns in European coniferous forests. More rugged terrains tend to harbour more species-rich forests than flat or gently undulating landscapes. This partly reflects diverse environmental conditions and partly higher isolation of habitats within topographically heterogeneous landscapes. These effects result in various processes increasing species richness, in particular: (i) habitat heterogeneity and spatial mass effects (e.g., Zelený, Li, \& Chytrý, 2010); (ii) locally buffered climate change and related refugial effects during the periods of macroclimatic oscillations (e.g., Sandel et al., 2011); and (iii) taxonomic diversification (e.g., Rosenzweig, 1995). Ruggedness may also be a proxy for poor accessibility, low management intensity, and high stand age of mountain forests, which favours vascular plant understorey richness (Ewald, 2008).

\section{Sclerophyllous forests}

In sclerophyllous forests, the highest numbers of species are predicted for areas with relatively low annual actual evapotranspiration and annual precipitation, and high annual potential evapotranspiration. Similarly, Naveh and Whittaker (1979) found increasing alpha diversity with decreasing rainfall in Mediterranean shrublands and woodlands in Israel. We assume that low precipitation combined with high energy inputs (i.e., high potential evapotranspiration) determines openness of forest stands in the Mediterranean, enabling the co-existence of forest specialists and light-demanding species with optima outside forests. The climatic causes of the modelled patterns are further supported by low summer rainfall amounts in some richness hotspots, e.g., in Sicily and south-western Greece. This suggests that high alpha diversity in sclerophyllous forests is related to areas with a more pronounced Mediterranean climate with its warm dry summers and mild wet winters. In warmer and drier areas, there is also a larger habitat-specific pool of sclerophyllous forest species, including a higher diversity of sclerophyllous trees and shrubs (Rivas-Martínez, 2011). 


\section{Methodological aspects of modelling species-richness patterns using vegetation-plot data}

In this study, we followed the recent trend of using vegetation-plot data to analyse broad-scale biogeographical phenomena (e.g., Jiménez-Alfaro et al., 2018; Wagner et al., 2017), integrating community ecology and macroecological modelling. This approach opens new perspectives in understanding relationships between species-richness patterns and spatially structured environmental factors (Divíšek \& Chytrý, 2018). However, it implies also several issues which must be carefully considered, namely: (i) uneven geographical coverage of vegetation-plot data, (ii) preferential sampling, and (iii) scale mismatch between plot-derived species richness and environmental variables.

The data used to infer alpha-diversity patterns must be sufficiently representative in terms of both geographical coverage and potential bias in richness estimates. We excluded marginal areas of the continent with scarce data and assumed that species-richness patterns might be well interpolated for the data gaps in non-marginal areas by our models, since (i) environmental conditions of such gaps were well represented in the data from more densely sampled areas, and (ii) all biogeographical regions and all main forest types within the study area were covered. The extent of the UTM grid used for prediction of alpha diversity almost fully fitted the range of environmental conditions covered by the vegetationplot data, with minor exceptions in the very northeast and southeast of the study area. That means model predictions were very rarely extrapolated in terms of environmental conditions. High prediction uncertainties were typical mostly of species-rich areas. Such a pattern is partly related to the fact that there are species-rich and species-poor communities often occurring and sampled at nearby sites, which 
might make the prediction output ambiguous. In contrast, areas dominated by species-poor communities had very low prediction uncertainties.

However, there were still parts of the geographic range of some forest types where vegetation-plot data were lacking, which was partly reflected in the maps of prediction uncertainty. Regarding the European sclerophyllous forest range, for instance, we had fewer plots from the Iberian Peninsula than from the Italian and Balkan Peninsulas. Also, the predicted richness hotspot on the Peloponnese, though corroborated by an expert evaluation, should be better supported by plot data. Thus, the predicted species-richness pattern may change slightly in the future with more data from the current gaps added. Another related inaccuracy might be in the predicted pattern for coniferous forests. Their range was estimated from the CORINE Land Cover database which does not distinguish native forest stands from conifer tree plantations. Therefore the predicted species richness might be overestimated in some areas with extensive plantations (e.g., the United Kingdom, northwestern Iberian Peninsula, and the Czech Republic).

The use of different resampling strategies that either explicitly preferred plots from undersampled areas or diminished the role of densely sampled areas in the models did not lead to notable differences in the resulting predictions (Appendix S2, Figures S2.21 and S2.25). This finding suggests that the species-richness pattern in European forests captured by the plot data is robust. In the end, we used the model based on the original (non-resampled) dataset, as it explained most of the variation and had the lowest mean of squared residuals, although its statistical parameters may be inflated due to high spatial autocorrelation at very short distances in some areas. The preferential selection of sampling sites is inherent to vegetation sampling in the European phytosociological school (Westhoff \& van der Maarel, 1978), and thus it probably affects most of the databases we used. We examined the potential effect of preferential sampling on predicted spatial patterns in alpha diversity by applying data resampling strategies that selected either richer or random plots from plot clusters in oversampled areas. However, the results were almost the same as those based on all data. Divišek and Chytrý (2018) also explicitly tested how predicted species-richness patterns may change if they are based on $50 \%$ of plots from the database with higher or lower species richness. In both cases, there was almost no difference in predicted spatial patterns compared with those based on non-resampled data, although the average predicted species richness might be slightly increased or decreased. Therefore, we assume that in the case of European forests preferential sampling does not lead to any strong bias in predicted spatial patterns of alpha diversity.

Our methodological approach involved a scale mismatch between species-richness data from small plots and rather coarse grain of environmental variables used. As our study focused on inter-regional differences in alpha diversity, which are primarily influenced by broad-scale environmental variables, we do not assume that such mismatch would have unduly affected our results. Given that the vegetation plots are not accurately georeferenced in some cases and that GIS layers of predictor variables differ in spatial resolution, we used buffer zones to calculate values of predictor variables within the surroundings 
of the plot coordinates provided in the database. The model prediction for a fixed plot size of $400 \mathrm{~m}^{2}$ was then projected into $5 \times 5 \mathrm{~km}$ grid cells based on the values of explanatory variables calculated within them, i.e., spatial units of the same size as those used as the model input. We consider this approach to be appropriate for integrating (i) fine-scale information on alpha diversity with more coarse-scale information on the environment, and (ii) different spatial resolutions of the explanatory variables which are unavoidable in this kind of broad-scale analysis. 


\section{List of table and figure legends}

Table 1: Summary statistics of the predictor variables used in modelling vascular plant alpha diversity across European forests, for all forests and for each forest type separately.

Table 2: Results of Random Forest models and spatial autocorrelation in model residuals for vascular plant alpha diversity across European forests.

Figure 1: Spatial distribution of forest vegetation plots, ranging from 100 to $1000 \mathrm{~m}^{2}$ in surface area, used as an input dataset for modelling alpha-diversity patterns $(n=73,134)$. The colours indicate the total number of vascular plant species recorded per plot (i.e., alpha diversity). For the purpose of visualization, alpha-diversity values displayed on this map were rescaled to $400 \mathrm{~m}^{2}$ (the most frequent plot size within the dataset) using the species-area relationship obtained from the data (Appendix S1, Figure S1.2a). The richest plots are displayed on the top. Analogous maps for the subsets of deciduous broadleaf, coniferous, and sclerophyllous forests are in Appendix S1, Figure S1.1.

Figure 2: Predicted alpha diversity of vascular plants across European forests based on Random Forest models for (a) all forests $(n=73,134)$; (c) deciduous broadleaf forests $(n=54,521)$; (d) coniferous forests $(n=15,978)$; and (e) sclerophyllous forests $(n=2635)$. All maps are provided in a UTM $5 \times 5$ $\mathrm{km}$ grid, with species numbers predicted for a plot size of $400 \mathrm{~m}^{2}$. Grid cells with forest area $<10 \%$ (according to the CORINE Land Cover database; Bossard, Feranec, \& Ot'ahel', 2000) are left white for (a) the 10\% threshold was applied to the area of all CORINE forest types; for (c) to broadleaf and mixed-forest area; for (d) to coniferous forest area; and for (e) to the broadleaf and mixed-forest area within the range of sclerophyllous forests according to Bohn et al. (2003).

(b) richness hotspots (light brown) and the top richness hotspots (black) of vascular plants in European forests for all forests - grid cells with predicted alpha-diversity values equal to or greater than the 95th and 99th percentile values, respectively. Analogous maps of richness hotspots for the subsets of deciduous broadleaf, coniferous, and sclerophyllous forests are in Appendix S2, Figure S2.13.

Figure 3: Integrated relative importance of predictor variables for explaining alpha-diversity patterns for all forests and for each forest type separately. The black part of the bars indicates the contribution of the 'Mean decrease in node impurity' to the integrated relative importance, the grey part indicates the contribution of the 'Mean decrease in accuracy' (see Appendix S1 for details on these measures, and Appendix S2 and Figure S2.14 for original values of these measures). LGM - Last Glacial Maximum.

Figure 4: Effects of the three top-ranked predictor variables on alpha diversity for all forests and for each forest type separately (partial dependence plots). The integrated importance scores are shown in parentheses. AET - actual evapotranspiration; PET - potential evapotranspiration; VRM - vector ruggedness measure. The effects of the lower-ranked predictors on alpha diversity are summarized in Appendix S2, Figures S2.15-S2.18. 
Table 1: Summary statistics of the predictor variables used in modelling vascular plant alpha diversity across European forests, for all forests and for each forest type separately.

\begin{tabular}{|c|c|c|c|c|c|c|c|c|c|c|c|c|}
\hline & \multicolumn{3}{|c|}{ All forests } & \multicolumn{3}{|c|}{ Deciduous broadleaf } & \multicolumn{3}{|c|}{ Coniferous } & \multicolumn{3}{|c|}{ Sclerophyllous } \\
\hline & Min & Mean & Max & Min & Mean & Max & Min & Mean & Max & Min & Mean & Max \\
\hline \multicolumn{13}{|l|}{ Current environment } \\
\hline Elevation [m a.s.l.] & -5 & 529 & 2583 & -5 & 473 & 2552 & -1 & 745 & 2583 & 1 & 390 & 1595 \\
\hline Terrain ruggedness $\left[\mathrm{VRM} \times 10^{4}\right]$ & 0 & 75 & 696 & 0 & 68 & 696 & 0 & 94 & 629 & 0 & 99 & 374 \\
\hline Heat load [index $\times 10^{4}$ ] & 5354 & 5978 & 6896 & 5368 & 5974 & 6693 & 5354 & 5993 & 6896 & 5366 & 5992 & 6403 \\
\hline Topsoil pH & 3 & 6 & 8 & 3 & 6 & 8 & 4 & 6 & 8 & 5 & 7 & 8 \\
\hline Limestone area [\%] & 0 & 17 & 100 & 0 & 16 & 100 & 0 & 19 & 100 & 0 & 25 & 100 \\
\hline Mean annual temperature $\left[{ }^{\circ} \mathrm{C}\right]$ & -2 & 9 & 19 & -1 & 9 & 19 & -2 & 7 & 18 & 7 & 14 & 19 \\
\hline Temperature seasonality [SD × 100] & 302 & 638 & 881 & 302 & 635 & 881 & 333 & 659 & 879 & 366 & 564 & 736 \\
\hline Annual precipitation $[\mathrm{mm} / \mathrm{yr}]$ & 290 & 835 & 2051 & 290 & 813 & 1985 & 348 & 925 & 2051 & 359 & 738 & 1487 \\
\hline Precipitation seasonality [coeff. of var.] & 7 & 26 & 101 & 8 & 25 & 101 & 7 & 27 & 99 & 15 & 41 & 88 \\
\hline Summer rainfall [\%] & 8 & 54 & 73 & 8 & 54 & 73 & 8 & 57 & 72 & 10 & 34 & 57 \\
\hline Annual potential evapotranspiration [mm/yr] & 374 & 783 & 1345 & 375 & 796 & 1345 & 374 & 712 & 1234 & 633 & 937 & 1305 \\
\hline Annual actual evapotranspiration [mm/yr] & 252 & 590 & 810 & 252 & 590 & 810 & 297 & 594 & 794 & 309 & 566 & 783 \\
\hline \multicolumn{13}{|l|}{ Environmental history } \\
\hline Presence/absence of an LGM glacier & \multicolumn{12}{|c|}{ binary variable } \\
\hline Temperature change since the LGM $\left[{ }^{\circ} \mathrm{C}\right]$ & 1 & 4 & 13 & 1 & 4 & 13 & 2 & 5 & 13 & 2 & 3 & 4 \\
\hline Precipitation change since the LGM [mm] & 1 & 43 & 567 & 1 & 42 & 567 & 1 & 46 & 293 & 16 & 63 & 443 \\
\hline \multicolumn{13}{|l|}{ Land cover } \\
\hline Forest area [\%] & 0 & 47 & 100 & 0 & 46 & 100 & 0 & 55 & 100 & 0 & 35 & 99 \\
\hline Mosaic land area [\%] & 0 & 22 & 100 & 0 & 23 & 100 & 0 & 20 & 98 & 0 & 15 & 80 \\
\hline Shrubland area [\%] & 0 & 6 & 94 & 0 & 5 & 88 & 0 & 7 & 91 & 0 & 19 & 94 \\
\hline Intensively cultivated land area [\%] & 0 & 16 & 100 & 0 & 18 & 100 & 0 & 8 & 93 & 0 & 15 & 97 \\
\hline
\end{tabular}

LGM - Last Glacial Maximum; SD - standard deviation of mean monthly temperatures; VRM - vector ruggedness measure. 
Table 2: Results of Random Forest models and spatial autocorrelation in model residuals for vascular plant alpha diversity across European forests.

\begin{tabular}{l|c|c|c|c}
\hline & All forests & $\begin{array}{c}\text { Deciduous } \\
\text { broadleaf }\end{array}$ & Coniferous & Sclerophyllous \\
\hline No. of cases (vegetation plots) & 73,134 & 54,521 & 15,978 & 2635 \\
Explained variation [\%] & 56.3 & 51.0 & 70.9 & 59.8 \\
Mean of squared residuals & 80.2 & 80.9 & 73.9 & 42.8 \\
Moran's / at 1 1 st lag distance ( \pm SD) & $-0.004 \pm 0.04$ & $-0.012 \pm 0.04$ & $-0.002 \pm 0.07$ & $-0.027 \pm 0.11$ \\
\hline
\end{tabular}




\section{Data accessibility}

Vegetation-plot data used to model the alpha-diversity patterns in European forests are stored in the

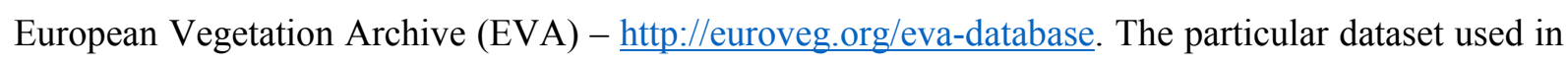
this study can be obtained from EVA upon request. Shapefiles containing the modelled alpha-diversity values, the identified richness hotspots as well as the maps of prediction uncertainty can be downloaded from the Figshare repository (https://doi.org/10.6084/m9.figshare.8005703.v2). All the other data used in this study are freely available from the cited publicly accessible databases.

\section{References}

Albuquerque, F. S., Olalla-Tárraga, M. Á., Montoya, D., \& Rodríguez, M. Á. (2011). Environmental determinants of woody and herb plant species richness patterns in Great Britain. Ecoscience, 18 , 394-401.

Araújo, M. B., Thuiller, W., Williams, P. H., \& Reginster, I. (2005). Downscaling European species atlas distributions to a finer resolution: implications for conservation planning. Global Ecology and Biogeography, 14, 17-30.

Axmanová, I., Chytrý, M., Zelený, D., Li, C.-F., Vymazalová, M., Danihelka, J., ... Diekmann, M. (2012). The species richness-productivity relationship in the herb layer of European deciduous forests. Global Ecology and Biogeography, 21, 657-667.

Barbero, M., Loisel, R., \& Quézel, P. (1992). Biogeography, ecology and history of Mediterranean Quercus ilex ecosystems. Vegetatio, 99/100, 19-34.

Bar-On, Y. M., Phillips, R., \& Milo, R. (2018). The biomass distribution on Earth. Proceedings of the National Academy of Sciences of the USA, 115, 6506-6511.

Barthlott, W., Hostert, A., Kier, G., Küper, W., Kreft, H., Mutke, J., ... Sommer, J. H. (2007). Geographic patterns of vascular plant diversity at continental to global scales. Erdkunde, 61, 305315.

Beck, J., Ballesteros-Mejia, L., Buchmann, C. M., Dengler, J., Fritz, S. A., Gruber, B., ... Dormann, C. F. (2012). What's on the horizon for macroecology? Ecography, 35, 673-683.

Bengtsson, J., Nilsson, S. G., Franc, A., \& Menozzi, P. (2000). Biodiversity, disturbances, ecosystem function and management of European forests. Forest Ecology and Management, 132, 39-50.

Bohn, U., Neuhäusl, R., Gollub, G., Hettwer, C., Neuhäuslová, Z., Raus, T., ... Weber, H. (2003). Map of the Natural Vegetation of Europe, Scale 1 : 2,500,000: Explanatory text with CD, Legend, Maps. Münster, DE: Landwirtschaftsverlag.

Bossard, M., Feranec, J., \& Ot'ahel', J. (2000). CORINE Land Cover technical guide - addendum 2000. Copenhagen, DK: European Environment Agency.

Breiman, L. (2001). Random Forests. Machine Learning, 45, 5-32. 
Bruelheide, H., Dengler, J., Jiménez-Alfaro, B., Purschke, O., Hennekens, S. M., Chytrý, M., ... Zverev, A. (2019). sPlot - a new tool for global vegetation analyses. Journal of Vegetation Science, $30,161-186$.

Chytrý, M. (2001). Phytosociological data give biased estimates of species richness. Journal of Vegetation Science, 12, 441-444.

Chytrý M., Ermakov N., Danihelka J., Hájek M., Hájková P., Horsák M., ... Zelený D. (2012). High species richness in hemiboreal forests of the northern Russian Altai, southern Siberia. Journal of Vegetation Science, 23, 605-616.

Chytrý, M., Hennekens, S. M., Jiménez-Alfaro, B., Knollová, I., Dengler, J., Jansen, F., ... Yamalov S. (2016). European Vegetation Archive (EVA): an integrated database of European vegetation plots. Applied Vegetation Science, 19, 173-180.

Cornell, H. V. \& Harrison, S. P. (2014). What are species pools and when are they important? Annual Review of Ecology, Evolution, and Systematics, 45, 45-67.

Cowling, R. M., Rundel, P. W., Lamont, B. B., Arroyo, M. K., \& Arianoutsou, M. (1996). Plant diversity in mediterranean-climate regions. Trends in Ecology and Evolution, 11, 362-366.

Crespo-Mendes, N., Laurent, A., Bruun, H. H., \& Hauschild, M. Z. (2019). Relationships between plant species richness and soil $\mathrm{pH}$ at the level of biome and ecoregion in Brazil. Ecological Indicators, 98, 266-275.

Currie, D. J. \& Paquin, V. (1987). Large-scale biogeographical patterns of species richness of trees. Nature, 329, 326-327.

Decocq, G., Aubert, M., Dupont, F., Alard, D., Saguez, R., Wattez-Franger, A., ... Bardat, J. (2004). Plant diversity in a managed temperate deciduous forest: understorey response to two silvicultural systems. Journal of Applied Ecology, 41, 1065-1079.

Divíšek, J. \& Chytrý, M. (2018). High-resolution and large-extent mapping of plant species richness using vegetation-plot databases. Ecological Indicators, 89, 840-851.

Ellenberg, H., Weber, H. E., Düll, R., Wirth, V., Werner, W., \& Paulissen D. (1991). Zeigerwerte von Pflanzen in Mitteleuropa. Scripta Geobotanica, 18, 1-248.

ESRI (2011). ArcGIS Desktop. Redlands, CA: Environmental Systems Research Institute.

Ewald, J. (2000). Long-term impact of forest pasture on the understorey of mountain forests in the Tegernsee Alps (Bavaria). Zeitschrift für Ökologie und Naturschutz, 9, 161-171.

Ewald, J. (2003). The calcareous riddle: Why are there so many calciphilous species in the Central European flora? Folia Geobotanica, 38, 357-366.

Ewald, J. (2008). Plant species richness in mountain forests of the Bavarian Alps. Plant Biosystems, $142,594-603$.

Francis, A. P., \& Currie, D. J. (2003). A globally consistent richness-climate relationship for angiosperms. The American Naturalist, 161, 523-536. 
Grace, J. B. (1999). The factors controlling species density in herbaceous plant communities: an assessment. Perspectives in Plant Ecology, Evolution and Systematics, 2, 1-28.

Härdtle, W., von Oheimb, G., \& Westphal, C. (2003). The effect of light and soil conditions on the species richness of the ground vegetation of deciduous forests in northern Germany (SchleswigHolstein). Forest Ecology and Management, 182, 327-338.

Hastie, T., Tibshirani, R., \& Friedman, J. (2009). The elements of statistical learning: data mining, inference, and prediction (2nd ed.). New York, NY: Springer-Verlag.

Hawkins, B. A., Field, R., Cornell, H. V., Currie, D. J., Guégan, J.-F., Kaufman, D. M., ... Turner, J. R. G. (2003). Energy, water, and broad-scale geographic patterns of species richness. Ecology, 84, $3105-3117$.

Hédl, R., Kopecký, M., \& Komárek, J. (2010). Half a century of succession in a temperate oakwood: from species-rich community to mesic forest. Diversity and Distributions, 16, 267-276.

Herben, T. (2000). Correlation between richness per unit area and the species pool cannot be used to demonstrate the species pool effect. Journal of Vegetation Science, 11, 123-126.

Honnay, O., Verheyen, K., Butaye, J., Jacquemyn, H., Bossuyt, B., \& Hermy, M. (2002). Possible effects of habitat fragmentation and climate change on the range of forest plant species. Ecology Letters, 5, 525-580.

Horvat, V., Biurrun, I., \& García-Mijangos, I. (2017). Herb layer in silver fir-beech forests in the western Pyrenees: Does management affect species diversity? Forest Ecology and Management, 385, 87-96.

Janišová, M., Michalcová, D., Bacaro, G., \& Ghisla, A. (2014). Landscape effects on diversity of semi-natural grasslands. Agriculture, Ecosystems \& Environment, 182, 47-58.

Janssen, J. A. M., Rodwell, J. S., García Criado, M., Gubbay, S., Haynes, T., Nieto, A., ... Valachovič M. (2016). European Red List of Habitats. Part 2. Terrestrial and freshwater habitats. Luxembourg City, LU: Publications Office of the European Union.

Jiménez-Alfaro, B., Chytrý, M., Mucina, L., Grace, J. B., \& Rejmánek, M. (2016). Disentangling vegetation diversity from climate-energy and habitat heterogeneity for explaining animal geographic patterns. Ecology and Evolution, 6, 1515- 1526

Jiménez-Alfaro, B., Girardello, M., Chytrý, M., Svenning, J.-C., Willner, W., Gégout, J.-C., .. Wohlgemuth, T. (2018). History and environment shape species pools and community diversity in European beech forests. Nature Ecology and Evolution, 2, 483-490.

Kier, G., Mutke, J., Dinerstein, E., Ricketts, T. H., Küper, W., Kreft, H., \& Barthlott, W. (2005). Global patterns of plant diversity and floristic knowledge. Journal of Biogeography, 32, 11071116.

Knollová, I., Chytrý, M., Tichý, L., \& Hájek, O. (2005). Stratified resampling of phytosociological databases: some strategies for obtaining more representative data sets for classification studies. Journal of Vegetation Science, 16, 479-486. 
Kooijman, A. M., Cammeraat, E. (2010). Biological control of beech and hornbeam affects species richness via changes in the organic layer, $\mathrm{pH}$ and soil moisture characteristics. Functional Ecology, $24,469-477$.

Kreft, H. \& Jetz, W. (2007). Global patterns and determinants of vascular plant diversity. Proceedings of the National Academy of Sciences of the USA, 104, 5925-5930.

Lahti, T. \& Lampinen, R. (1999). From dot maps to bitmaps: Atlas Florae Europaeae goes digital. Acta Botanica Fennica, 162, 5-9.

Lenoir, J., Gégout, J.-C., Guisan, A., Vittoz, P., Wohlgemuth, T., Zimmermann, N. E., ... Svenning, J.-C. (2010). Cross-scale analysis of the region effect on vascular plant species diversity in southern and northern European mountain ranges. PLOS ONE, 5, e15734.

Liaw, A. \& Wiener, M. (2002). Classification and regression by randomForest. R News, 2, 18-22.

Magri, D. (2008). Patterns of post-glacial spread and the extent of glacial refugia of European beech (Fagus sylvatica). Journal of Biogeography, 35, 450-463.

Myers, N., Mittermeier, R. A., Mittermeier, C. G., da Fonseca, G. A. B., \& Kent, J. (2000). Biodiversity hotspots for conservation priorities. Nature, 403, 853-858.

Naveh, Z. \& Whittaker, R. H. (1979). Structural and floristic diversity of shrublands and woodlands in northern Israel and other Mediterranean areas. Vegetatio, 41, 171-190.

Paillet, Y., Bergès, L., Hjältén, J., Ódor, P., Avon, C., Bernhardt-Römermann, M., ... Virtanen, R. (2010). Biodiversity differences between managed and unmanaged forests: meta-analysis of species richness in Europe. Conservation Biology, 24, 101-112.

Pärtel, M. (2002). Local plant diversity patterns and evolutionary history at the regional scale. Ecology, 83, 2361-2366.

Parviainen, J. (2005). Virgin and natural forests in the temperate zone of Europe. Forest Snow and Landscape Research, 79, 9-18.

Pausas, J. G. (1994). Species richness patterns in the understorey of Pyrenean Pinus sylvestris forest. Journal of Vegetation Science, 5, 517-524.

Pereira, H. M., Leadley, P. W., Proença, V., Alkemade, R., Scharlemann, J. P. W., FernandezManjarrés, J. F., ... Walpole, M. (2010). Scenarios for global biodiversity in the 21st century. Science, 330, 1496-1501.

Peringer, A., Siehoff, S., Chetelat, J., Spiegelberger, T., Buttler, A., \& Gillet, F. (2013). Past and future landscape dynamics in pasture-woodlands of the Swiss Jura Mountains under climate change. Ecology and Society, 18, 11.

Prasad, A. M., Iverson, L. R., \& Liaw, A. (2006). Newer classification and regression tree techniques: bagging and Random Forests for ecological prediction. Ecosystems, 9, 181-199.

Prendergast, J. R., Quinn, R. M., Lawton, J. H., Eversham, B. C., \& Gibbons, D. W. (1993). Rare species, the coincidence of diversity hotspots and conservation strategies. Nature, 365, 335-337. 
Qian, H., White, P. S., \& Song, J.-S. (2007). Effects of regional vs. ecological factors on plant species richness: an intercontinental analysis. Ecology, 88, 1440-1453.

QGIS Development Team (2015). QGIS Geographic Information System. Open source geospatial foundation project.

R Core Team (2016). R: A language and environment for statistical computing. Vienna, AT: R Foundation for Statistical Computing.

Rivas-Martínez, S. (Ed.) (2011). Map of series, geoseries and geopermaseries of vegetation in Spain. Itinera Geobotanica, 18, 5-424 (in Spanish).

Robert, N., Vidal, C., Colin, A., Hervé, J.-C., Hamza, N., \& Cluzeau, C. (2012). France. In E. Tomppo, T. Gschwantner, M. Lawrence \& R. E. McRoberts (Eds.), National Forest Inventories. Pathways for Common Reporting (pp. 207-221). London, UK: Springer.

Ronk, A., Szava-Kovats, R., \& Pärtel, M. (2015). Applying the dark diversity concept to plants at the European scale. Ecography, 38, 1015-1025.

Rosenzweig, M. L. (1995). Species diversity in space and time. Cambridge, UK: Cambridge University Press.

Sandel, B., Arge, L., Dalsgaard, B., Davies, R. G., Gaston, K. J., Sutherland, W. J., \& Svenning, J.-C. (2011). The influence of late Quaternary climate-change velocity on species endemism. Science, $334,660-664$.

Schaminée, J. H. J., Chytrý, M., Hennekens, S. M., Janssen, J. A. M., Jiménez-Alfaro, B., Knollová, I., ... Data-providers (2014). Vegetation analysis and distribution maps for EUNIS habitats. Report EEA/NSV/14/006. Copenhagen, DK: European Environment Agency.

Svenning, J.-C. \& Skov, F. (2004). Limited filling of the potential range in European tree species. Ecology Letters, 7, 565-573.

Svenning, J.-C., Normand, S., \& Skov, F. (2009). Plio-Pleistocene climate change and geographic heterogeneity in plant diversity-environment relationships. Ecography, 32, 13-21.

Szymura, T. (2012). How does recent vegetation reflect previous systems of forest management? Polish Journal of Ecology, 60, 859-886.

Tichý, L. (2002). JUICE, software for vegetation classification. Journal of Vegetation Science, 13, $451-453$.

Tzedakis, P. C., Emerson, B. C., \& Hewitt, G. M. (2013). Cryptic or mystic? Glacial tree refugia in northern Europe. Trends in Ecology and Evolution, 28, 696-704.

Ujházyová, M., Ujházy, K., Chytrý, M., Willner, W., Čiliak, M., Máliš, F., \& Slezák, M. (2016). Diversity of beech forest vegetation in the Eastern Alps, Bohemian Massif and the Western Carpathians. Preslia, 88, 435-457.

Ulloa Ulloa, C., Acevedo-Rodríguez, P., Beck, S., Belgrano, M. J., Bernal, R., Berry, P. E. ... Jørgensen, P. M. (2017). An integrated assessment of the vascular plant species of the Americas. Science, 358, 1614-1617. 
Veselič, Ž. (Ed.), Breznikar, A., Grecs, Z., Habič, Š., Hostnik, R., Diaci, J., \& Golob, A. (2008).

Forest management by mimicking nature: close-to-nature forest management in Slovenia: how to conserve forests by using them. Ljubljana, SI: Slovenia Forest Service.

Wagner, V., Chytrý, M., Jiménez-Alfaro, B., Pergl, J., Hennekens, S., Biurrun, I., ... Pyšek, P. (2017). Alien plant invasions in European woodlands. Diversity and Distributions, 23, 969-981.

Westhoff, V. \& van der Maarel, E. (1978). The Braun-Blanquet approach. 2nd ed. In R. H. Whittaker (Ed.), Classification of plant communities (2nd ed., pp. 619-729). The Hague, NL: Junk.

Whittaker, R. H. (1972). Evolution and measurement of species diversity. Taxon, 21, 213-251.

Wohlgemuth, T. (1998). Modelling floristic species richness on a regional scale: a case study in Switzerland. Biodiversity and Conservation, 7, 159-177.

Wulff, E. W. (1935). Versuch einer Einteilung der Vegetation der Erde in pflanzengeographische Gebiete auf Grund der Artenzahl. Repertorium Specierum Novarum Regni Vegetabilis, 12, 57-83.

Zelený, D., Li, C.-F., \& Chytrý, M. (2010). Pattern of local plant species richness along a gradient of landscape topographical heterogeneity: result of spatial mass effect or environmental shift? Ecography, 33, 578-589.

Zerbe, S., Schmidt, I., \& Betzin, J. (2007). Indicators for plant species richness in pine (Pinus sylvestris L.) forests of Germany. Biodiversity and Conservation, 16, 3301-3316.

\section{Biosketch}

Martin Večeřa is a $\mathrm{PhD}$ student interested in biogeography and ecology, with a particular focus on patterns of species diversity. His research integrates broad-scale mapping and spatial modelling with community ecology.

Author contributions: M.V., J.D., J.L., B.J.-A. \& M.C. conceived the ideas; M.V., J.D., J.L. \& M.C. designed methodology; J.L., I.B., E.A., J.A.C., A.Č., M.Ć., P.D., J.E., F.F.-G., J.-C.G., A.I., U.J., F.J., Z.K., V.R., J.S.R., J.H.J.S., U.Š., G.S., K.V., R.V., W.W., T.W. \& M.C. significantly contributed the data; M.V., B.J.-A., I.K., M.R. \& M.C. prepared and processed the dataset of vegetation plots; M.V. \& J.D. analysed the data; M.V., J.D., J.L., B.J.-A., I.B., E.A., J.A.C., A.Č., G.C.J., P.D., J.E., F.F.-G., J.C.G., A.I., U.J., F.J., Z.K., V.R., U.Š., J.-C.S., G.S., W.W., T.W. \& M.C. interpreted the results and/or regional specifics in alpha-diversity patterns; M.V. \& M.C. led the writing of the manuscript. All authors commented on the manuscript drafts.

\section{Appendices}

Appendix S1 - SUPPLEMENTARY MATERIALS AND METHODS

Appendix S2 - SUPPLEMENTARY RESULTS 


\title{
Alpha diversity of vascular plants in European forests
}

\author{
Journal of Biogeography \\ Martin Večeřa, Jan Divíšek, Jonathan Lenoir, Borja Jiménez-Alfaro, Idoia Biurrun, Ilona Knollová, Emiliano \\ Agrillo, Juan Antonio Campos, Andraž Čarni, Guillermo Crespo Jiménez, Mirjana Ćuk, Panayotis Dimopoulos, \\ Jörg Ewald, Federico Fernández-González, Jean-Claude Gégout, Adrian Indreica, Ute Jandt, Florian Jansen, \\ Zygmunt Kącki, Valerijus Rašomavičius, Marcela Řezníčková, John S. Rodwell, Joop H. J. Schaminée, \\ Urban Šilc, Jens-Christian Svenning, Grzegorz Swacha, Kiril Vassilev, Roberto Venanzoni, Wolfgang Willner, \\ Thomas Wohlgemuth \& Milan Chytrý
}

\section{CONTENTS}

\section{Appendix S1 - SUPPLEMENTARY MATERIALS AND METHODS}

Overview of input vegetation-plot data used $\quad 2$

Species-area relationships for visualization of alpha diversity of vegetation plots $\quad 6$

Description of environmental variables used as predictors $\quad 8$

$\begin{array}{ll}\text { Correlation matrices of predictors } & 10\end{array}$

Random forests - model fitting and relative importance measures $\quad 14$

Resampling procedure to reduce local oversampling $\quad 14$

\section{Appendix S2 - SUPPLEMENTARY RESULTS}

Examples of fine-scale alpha-diversity maps in zoomed windows 15

$\begin{array}{ll}\text { Spatial correlograms } & 16\end{array}$

Supplement to the richness hotspots $\quad 20$

Supplement to the relative importance of predictors $\quad 21$

$\begin{array}{ll}\text { Maps of prediction uncertainty } & 27\end{array}$

Range of environmental conditions in plot data as covered by the grid used for prediction $\quad 28$

Tests of stability of the predicted alpha-diversity patterns 29 


\section{Appendix S1 - SUPPLEMENTARY MATERIALS AND METHODS}

Overview of input vegetation-plot data used

Table S1.1 - Contributing vegetation-plot databases: number (n) and percentage (\%) of plots used in the final dataset, $\mathrm{N}=73,134$.

\begin{tabular}{|c|c|c|c|c|c|}
\hline \multirow[t]{2}{*}{ Name } & \multirow[t]{2}{*}{ GIVD* } & \multirow[t]{2}{*}{ Custodian } & \multirow[t]{2}{*}{ Deputy custodian } & \multicolumn{2}{|c|}{$\begin{array}{l}\text { EUNIS-classified } \\
\text { plots }\end{array}$} \\
\hline & & & & $\mathrm{n}$ & $\%$ \\
\hline Austrian Vegetation Database & EU-AT-001 & Wolfgang Willner & - & 458 & 0.6 \\
\hline Balkan Vegetation Database & EU-00-019 & Kiril Vassilev & Hristo Pedashenko & 1434 & 2.0 \\
\hline Croatian Vegetation Database & EU-HR-002 & Željko Škvorc & Daniel Krstonošić & 2201 & 3.0 \\
\hline $\begin{array}{l}\text { Czech National Phytosociological } \\
\text { Database }\end{array}$ & EU-CZ-001 & Milan Chytrý & Ilona Knollová & 9247 & 12.6 \\
\hline $\begin{array}{l}\text { Database of Forest Vegetation in } \\
\text { Republic of Serbia \& Vegetation } \\
\text { Database of Northern Part of } \\
\text { Serbia (AP Vojvodina) }\end{array}$ & $\begin{array}{l}\text { EU-RS-003 } \\
\qquad \begin{array}{l}\& \\
\text { EU-RS-004 }\end{array}\end{array}$ & Mirjana Ćuk & - & 227 & 0.3 \\
\hline $\begin{array}{l}\text { Dutch National Vegetation } \\
\text { Database }\end{array}$ & EU-NL-001 & Joop Schaminée & $\begin{array}{c}\text { Stephan } \\
\text { Hennekens }\end{array}$ & 3659 & 5.0 \\
\hline EcoPlant & EU-FR-005 & $\begin{array}{l}\text { Jean-Claude } \\
\text { Gégout }\end{array}$ & Ingrid Seynave & 2665 & 3.6 \\
\hline $\begin{array}{l}\text { European Mire Vegetation } \\
\text { Database }\end{array}$ & EU-00-022 & Tomáš Peterka & Martin Jiroušek & 9 & 0.01 \\
\hline $\begin{array}{l}\text { French National Forest } \\
\text { Inventory** }\end{array}$ & - & & - & 9235 & 12.6 \\
\hline $\begin{array}{l}\text { GVRD Vegetation Reference } \\
\text { Database Halle }\end{array}$ & EU-DE-014 & Ute Jandt & Helge Bruelheide & 3450 & 4.7 \\
\hline Hellenic Natura 2000 Database & EU-GR-005 & $\begin{array}{c}\text { Panayotis } \\
\text { Dimopoulos }\end{array}$ & Ioannis Tsiripidis & 1770 & 2.4 \\
\hline $\begin{array}{l}\text { Hellenic Woodland Database \& } \\
\text { Hellenic Beech Forests Database }\end{array}$ & $\begin{array}{l}\text { EU-GR-006 } \\
\& \\
\text { EU-GR-007 }\end{array}$ & Ioannis Tsiripidis & - & 467 & 0.6 \\
\hline $\begin{array}{l}\text { Iberian and Macaronesian } \\
\text { Vegetation Information System } \\
\text { (SIVIM) }\end{array}$ & EU-00-004 & Xavier Font & - & 772 & 1.1 \\
\hline INBOVEG & EU-BE-002 & Els De Bie & - & 1286 & 1.8 \\
\hline Irish Vegetation Database & EU-IE-001 & Úna FitzPatrick & Lynda Weekes & 745 & 1.0 \\
\hline Lithuanian Vegetation Database & EU-LT-001 & $\begin{array}{c}\text { Valerijus } \\
\text { Rašomavičius } \\
\end{array}$ & Domas Uogintas & 473 & 0.6 \\
\hline Polish Vegetation Database & EU-PL-001 & Zygmunt Kącki & Grzegorz Swacha & 5868 & 8.0 \\
\hline Romanian Forest Database & EU-RO-007 & Adrian Indreica & $\begin{array}{l}\text { Pavel Dan } \\
\text { Turtureanu }\end{array}$ & 2176 & 3.0 \\
\hline SE Europe Forest Database & EU-00-021 & Andraž Čarni & - & 1609 & 2.2 \\
\hline $\begin{array}{l}\text { Semi-natural Grassland } \\
\text { Vegetation Database of Latvia }\end{array}$ & EU-LV-001 & Solvita Rūsiṇa & - & 44 & 0.1 \\
\hline SIVIM Catalonia & EU-00-004 & Xavier Font & - & 19 & 0.03 \\
\hline
\end{tabular}




\begin{tabular}{|c|c|c|c|c|c|}
\hline SIVIM Deciduous forests & EU-00-023 & $\begin{array}{c}\text { Juan Antonio } \\
\text { Campos }\end{array}$ & Xavier Font & 1213 & 1.7 \\
\hline SIVIM Floodplain forests & EU-00-024 & Idoia Biurrun & Xavier Font & 1052 & 1.4 \\
\hline SIVIM Sclerophyllous forests & EU-00-004 & $\begin{array}{c}\text { Federico } \\
\text { Fernández- } \\
\text { González }\end{array}$ & Xavier Font & 406 & 0.6 \\
\hline Slovak Vegetation Database & EU-SK-001 & Milan Valachovič & Jozef Šibík & 3426 & 4.7 \\
\hline SOPHY & EU-FR-003 & Henry Brisse & Patrice de Ruffray & 1649 & 2.3 \\
\hline Swiss Forest Vegetation Database & EU-CH-005 & $\begin{array}{c}\text { Thomas } \\
\text { Wohlgemuth }\end{array}$ & - & 4281 & 5.9 \\
\hline The Nordic Vegetation Database & EU-00-018 & Jonathan Lenoir & $\begin{array}{l}\text { Jens-Christian } \\
\text { Svenning }\end{array}$ & 520 & 0.7 \\
\hline $\begin{array}{l}\text { UK National Vegetation } \\
\text { Classification Database }\end{array}$ & EU-GB-001 & John Rodwell & - & 313 & 0.4 \\
\hline Vegetation Database of Slovenia & EU-SI-001 & Urban Šilc & - & 1605 & 2.2 \\
\hline $\begin{array}{l}\text { Vegetation Database of Habitats } \\
\text { in the Italian Alps }\end{array}$ & EU-IT-010 & Laura Casella & Pierangela Angelini & 1182 & 1.6 \\
\hline $\begin{array}{l}\text { Vegetation Plot Database - } \\
\text { Sapienza University of Rome }\end{array}$ & EU-IT-011 & Emiliano Agrillo & Fabio Attorre & 4160 & 5.7 \\
\hline $\begin{array}{l}\text { Vegetation-Plot Database of the } \\
\text { University of the Basque Country }\end{array}$ & EU-00-011 & Idoia Biurrun & $\begin{array}{l}\text { Itziar García- } \\
\text { Mijangos }\end{array}$ & 1389 & 1.9 \\
\hline VegetWeb & EU-DE-013 & Florian Jansen & Jörg Ewald & 1969 & 2.7 \\
\hline $\begin{array}{l}\text { Vegltaly, the Italian Vegetation } \\
\text { database }\end{array}$ & EU-IT-001 & Roberto Venanzoni & Flavia Landucci & 764 & 1.0 \\
\hline VegMV & EU-DE-001 & Florian Jansen & Christian Berg & 1391 & 1.9 \\
\hline
\end{tabular}

* Global Index of Vegetation-plot Databases ID

\footnotetext{
** From the French National Forest Inventory database, we used only plots sampled during the growing season (from April to September) and excluded plots that could be clearly identified as plantations of non-native trees or stands heavily affected by natural disturbances (e.g., windstorm). The data we used were sampled between 2009 and 2014.
} 
Table S1.2 - Numbers of plots $(\mathrm{n})$ in the final dataset $(\mathrm{N}=73,134)$ belonging to particular forest habitat types of the revised EUNIS classification as used in the European Red List of Habitats (G1 Deciduous broadleaf forests, G2 Sclerophyllous forests, G3 Coniferous forests).

\begin{tabular}{|c|c|c|}
\hline Code & Name & $\mathbf{n}$ \\
\hline G1.1 & Temperate and boreal softwood riparian woodland & 1356 \\
\hline G1.2a & Alnus woodland on riparian and upland soils & 3060 \\
\hline $\mathrm{G} 1.2 \mathrm{~b}$ & Temperate and boreal hardwood riparian woodland & 1034 \\
\hline G1.3 & Mediterranean and Macaronesian riparian woodland & 661 \\
\hline G1.4 & Broadleaved swamp woodland on non-acid peat & 1885 \\
\hline G1.5 & Broadleaved swamp woodland on acid peat & 800 \\
\hline G1.6a & Fagus woodland on non-acid soils & 11853 \\
\hline G1.6b & Fagus woodland on acid soils & 4331 \\
\hline G1.7a & Temperate and submediterranean thermophilous deciduous woodland & 6654 \\
\hline G1.7b & Mediterranean thermophilous deciduous woodland & 41 \\
\hline G1.8 & Acidophilous Quercus woodland & 4394 \\
\hline G1.9a & $\begin{array}{l}\text { Temperate and boreal mountain Betula and Populus tremula woodland on } \\
\text { mineral soils }\end{array}$ & 50 \\
\hline G1.9b & $\begin{array}{l}\text { Mediterranean mountain Betula and Populus tremula woodland on } \\
\text { mineral soils }\end{array}$ & 8396 \\
\hline G1.Aa & Carpinus and Quercus mesic deciduous woodland & 5303 \\
\hline G1.Ab & Ravine woodland & 4677 \\
\hline G1.Ba & Alnus cordata woodland & 26 \\
\hline G2.1 & Mediterranean evergreen Quercus woodland & 2608 \\
\hline G2.2 & Mainland laurophyllous woodland & 24 \\
\hline G2.5a & South-Aegean Phoenix grove & 3 \\
\hline G3.1a & Temperate mountain Picea woodland & 5254 \\
\hline G3.1b & Temperate mountain Abies woodland & 2791 \\
\hline G3.1c & Mediterranean mountain Abies woodland & 13 \\
\hline G3.2 & Temperate subalpine Larix, Pinus cembra and Pinus uncinata woodland & 565 \\
\hline G3.4a & Temperate continental Pinus sylvestris woodland & 4704 \\
\hline G3.4b & Temperate and submediterranean montane Pinus sylvestris-Pinus nigra woodland & 1026 \\
\hline G3.4c & Mediterranean montane Pinus sylvestris-Pinus nigra woodland & 49 \\
\hline G3.6 & Mediterranean and Balkan subalpine Pinus heldreichii-Pinus peuce woodland & 44 \\
\hline G3.7 & Mediterranean lowland to submontane Pinus woodland & 470 \\
\hline G3.9a & Taxus baccata woodland & 29 \\
\hline G3.9b & Mediterranean Cupressaceae woodland & 122 \\
\hline G3.A & Picea taiga woodland & 6 \\
\hline G3.B & Pinus sylvestris taiga woodland & 2 \\
\hline G3.Da & Pinus mire woodland & 323 \\
\hline G3.Db & Picea mire woodland & 580 \\
\hline
\end{tabular}



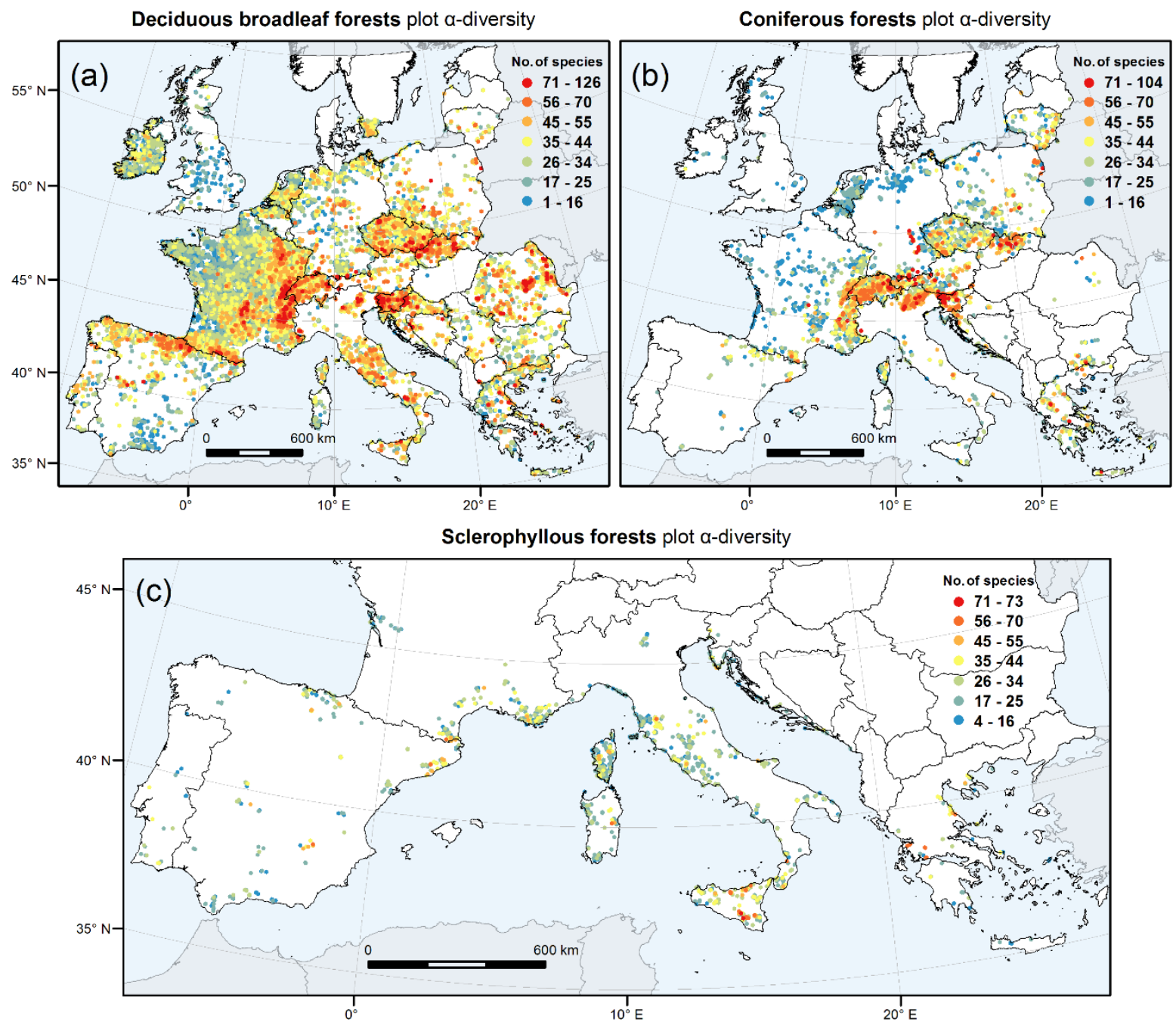

Figure S1.1 - Spatial distribution of vegetation plots, ranging from 100 to $1000 \mathrm{~m}^{2}$ in surface area, used as input datasets for modelling alpha-diversity patterns in (a) deciduous broadleaf forests, $\mathrm{n}=54,521$; (b) coniferous forests, $n=15,978$; and (c) sclerophyllous forests, $n=2635$. The colours indicate the total number of vascular plant species recorded per plot (i.e., alpha diversity). For the purpose of visualization, alpha diversity values displayed on these maps were rescaled to $400 \mathrm{~m}^{2}$ (the most frequent plot size within the dataset) using the speciesarea relationship obtained from the data (Appendix S1, Figures S1.2b, c, d). The richest plots are displayed on the top. 
Species-area relationships for visualization of alpha diversity of vegetation plots

\section{(a) All forests}

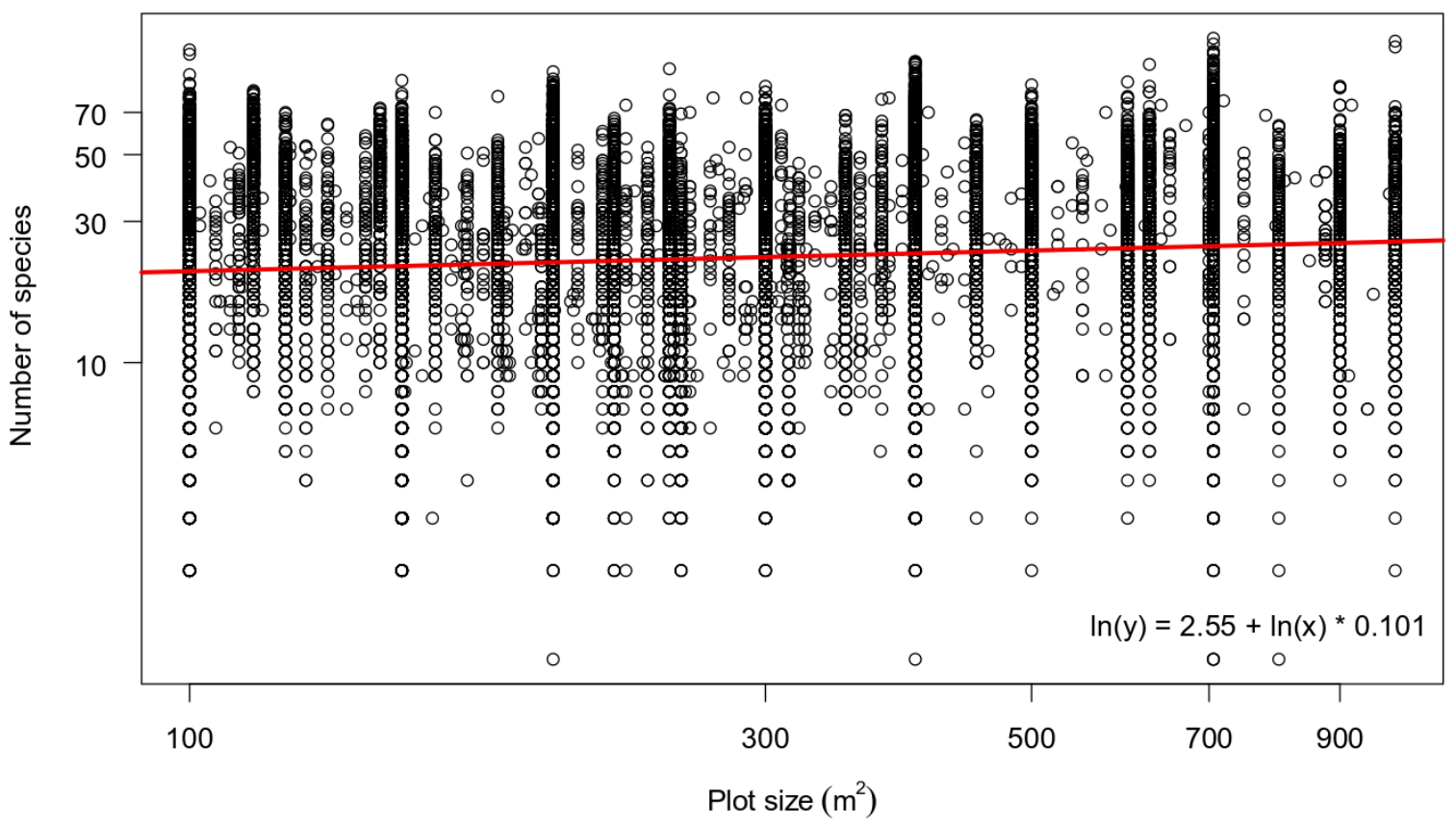

(b) Deciduous broadleaf forests

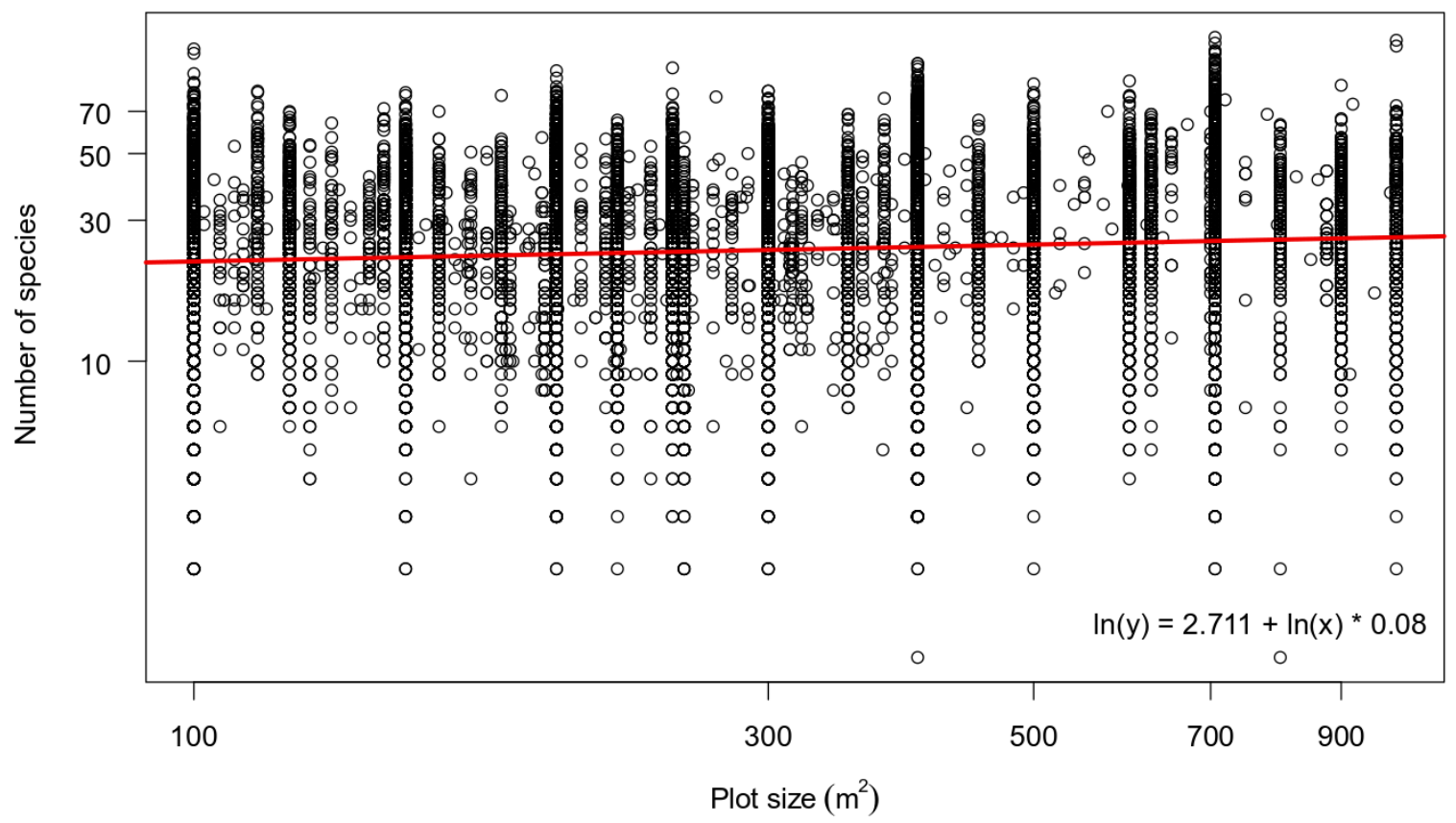


(c) Coniferous forests

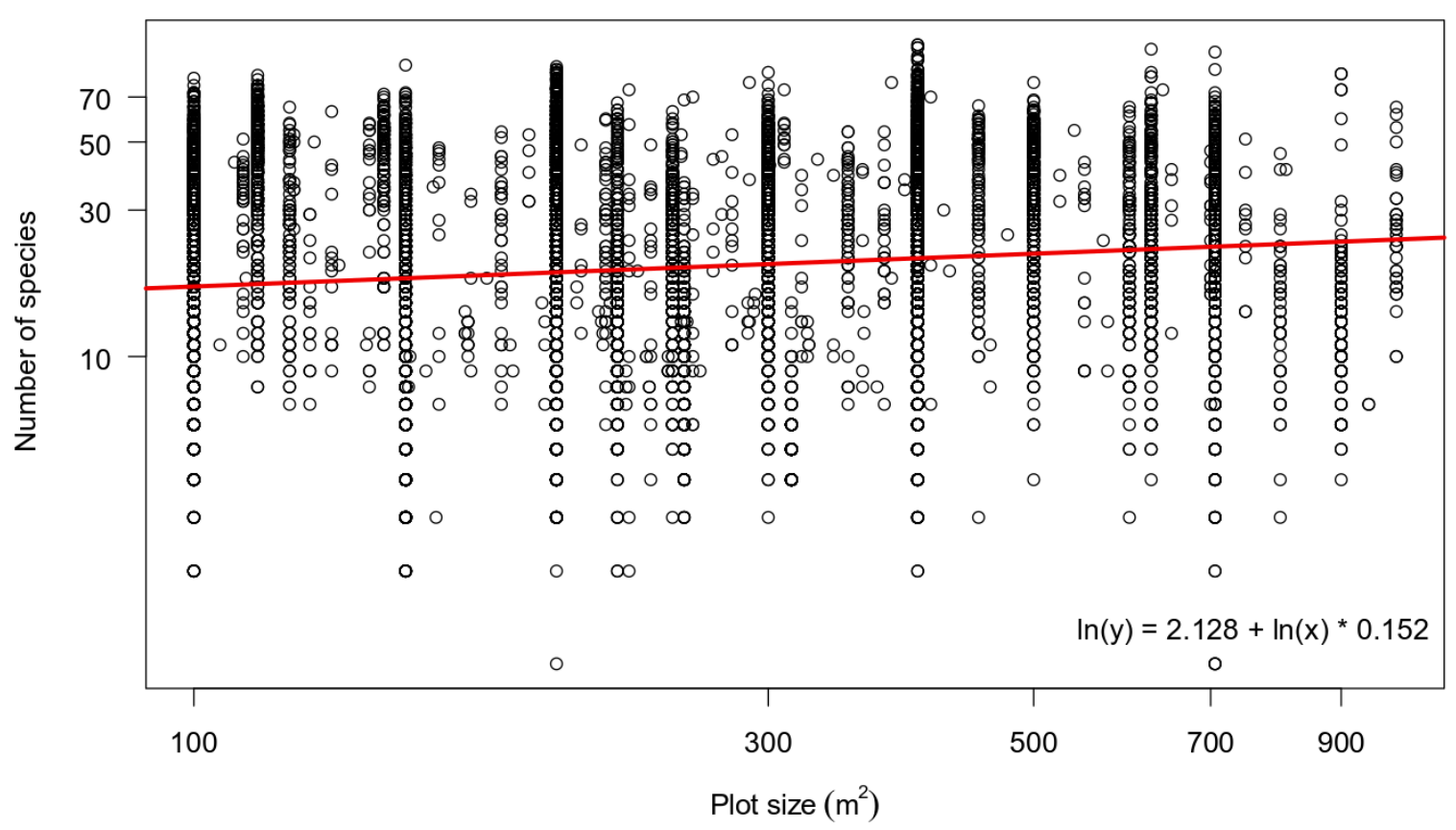

(d) Sclerophyllous forests

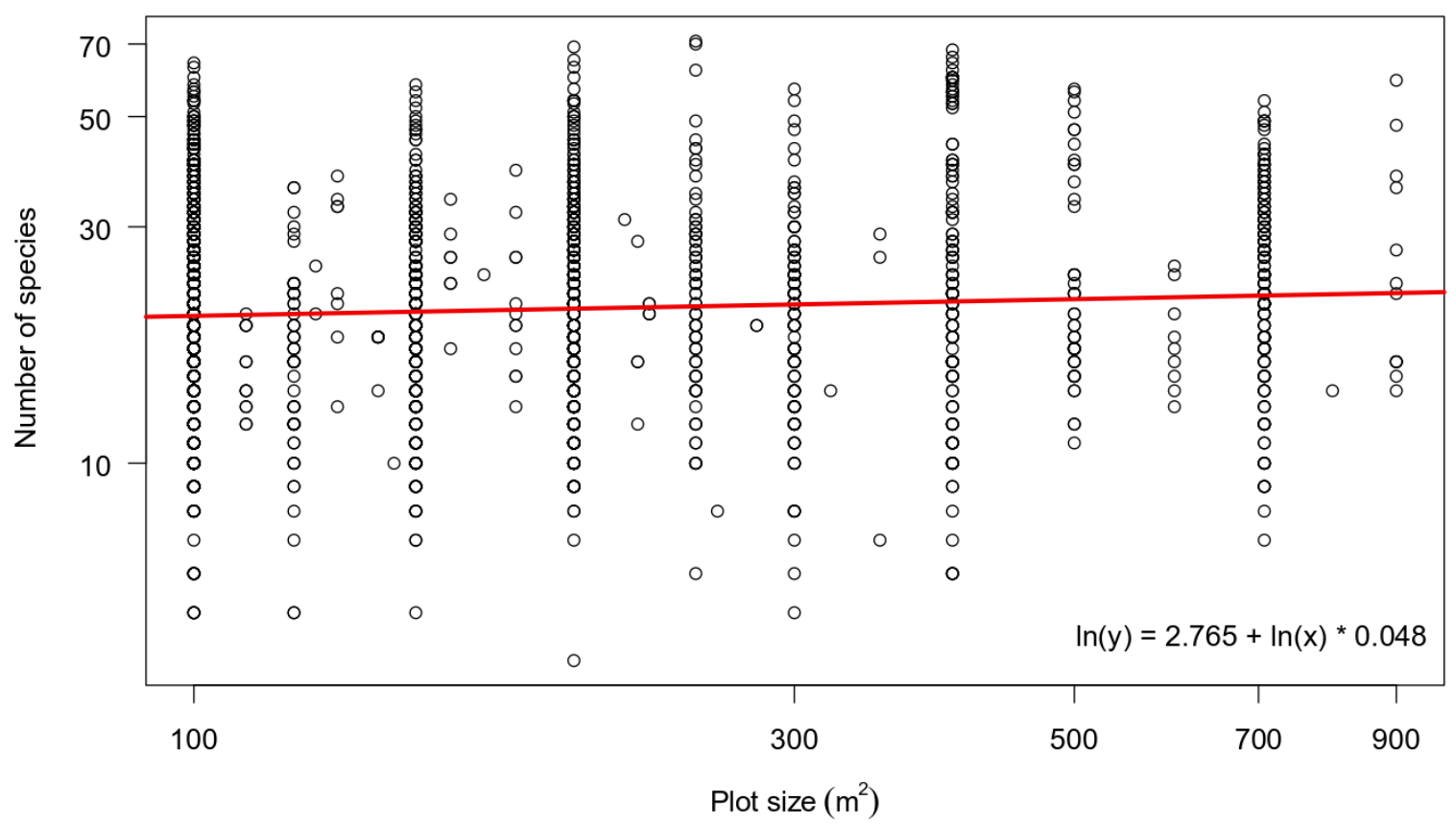

Figure S1.2 - Species-area relationships used for the visualization of alpha diversity of vegetation plots rescaled to $400 \mathrm{~m}^{2}$ for all forests and for each forest type separately (see also Figure S1.1), the axes are in a logarithmic scale. 
Description of environmental variables used as predictors

\section{(i) Current environment}

Topographic variables were all derived from the global digital elevation model with a spatial resolution of $\sim 90 \mathrm{~m}$ at the equator (Jarvis, Reuter, Nelson, \& Guevara, 2008): elevation; terrain ruggedness (calculated as a vector ruggedness measure (VRM) according to Sappington, Longshore, \& Thompson, 2007); and heat load index (McCune \& Keon, 2002; Equation 3). Terrain ruggedness was used as a proxy to capture the environmental heterogeneity occurring within a $25 \mathrm{~km}^{2}$ buffer zone. Substrate variables are topsoil $p H$ (measured in water) with a spatial resolution of $\sim 4.3 \mathrm{~km}$ (Wieder, Boehnert, Bonan, \& Langseth, 2014) and area of limestone bedrock derived from the European Soil Database (CEC, 2004; Panagos, Van Liedekerke, Jones, \& Montanarella, 2012). Regarding the climatic variables, we extracted data from the WorldClim database (version 1.4.; Hijmans, Cameron, Parra, Jones, \& Jarvis, 2005) and the Consortium for Spatial Information (CGIAR-CSI) database (http://www.cgiarcsi.org/data) with a spatial resolution of $\sim 1 \mathrm{~km}$ at the equator: mean annual temperature; temperature seasonality; annual precipitation; precipitation seasonality; rainfall during the vegetation period (hereafter summer rainfall, the ratio of precipitation in April-September to annual precipitation - the lower values, the more Mediterranean climate); annual potential evapotranspiration (Zomer, Trabucco, Bossio, van Straaten, \& Verchot, 2008); and annual actual evapotranspiration (Trabucco \& Zomer, 2010).

(ii) Environmental history

This group contains the following variables: presencelabsence of a Last Glacial Maximum (LGM) glacier (Ehlers, Gibbard, \& Hughes, 2011) within at least 50\% of the buffer zone surrounding each plot; temperature change since the LGM calculated as a mean of the differences in mean annual temperature between (i) "LGM" and "Mid-Holocene", and (ii) "Mid-Holocene" and "Present" conditions; and precipitation change since the $L G M$ calculated as a mean of the differences in annual precipitation between (i) "LGM" and "Mid-Holocene", and (ii) "Mid-Holocene" and "Present" conditions. Past climatic conditions were available at a spatial resolution of $\sim 1 \mathrm{~km}$ at the equator based on the CCSM4 model available in the WorldClim database (version 1.4.; Hijmans et al., 2005). 
Figure S1.3 - Buffer zone $\left(25 \mathrm{~km}^{2}\right)$ around a vegetation plot used to calculate mean values of quantitative predictor variables and the proportion of occupancy for categorical variables. The calculated values were then assigned to the respective plot.

\section{(iii) Land cover}

Aggregated land-cover types were extracted from the CORINE 2000 Land Cover database (Bossard, Feranec, \& Ot'ahel', 2000): forests (311 broadleaf, 312 coniferous, and 313 mixed forests); mosaic lands (231 pastures, 321 natural grasslands, 242 complex cultivation patterns, 243 cultivated land with significant areas of natural vegetation, and 244 agro-forestry areas); shrublands (322 moors and heathland, 323 sclerophyllous vegetation, and 324 transitional woodland shrub); and intensively cultivated lands (211 non-irrigated arable land, 212 permanently irrigated land, 213 rice fields, 221 vineyards, 222 fruit trees and berry plantations, 223 olive groves, and 241 annual crops associated with permanent crops). The proportion of occupancy of these four land-cover categories within the $25 \mathrm{~km}^{2}$ buffer zones was used as a predictor. 


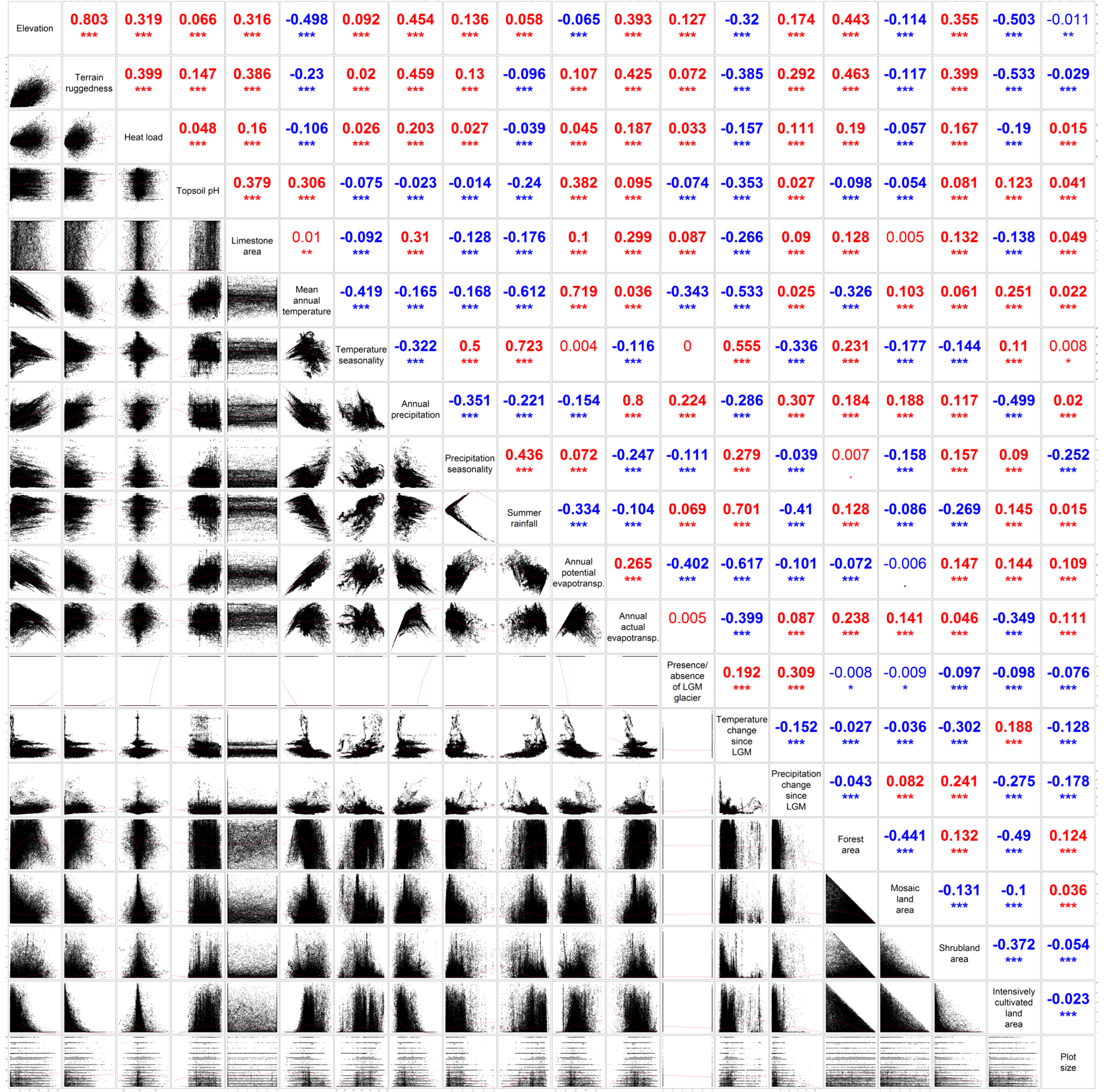

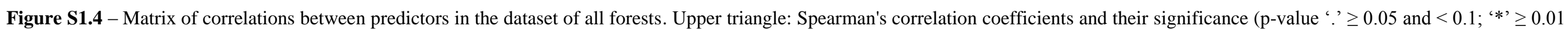

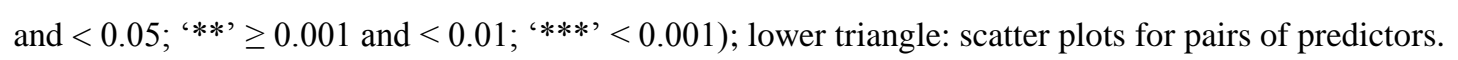




\begin{tabular}{|c|c|c|c|c|c|c|c|c|c|c|c|c|c|c|c|c|c|c|c|}
\hline Elevation & $\underset{* * *}{0.815}$ & $\underset{* * *}{0.333}$ & $\underset{* * *}{0.052}$ & $\underset{* * *}{0.288}$ & $\begin{array}{c}-0.41 \\
* * *\end{array}$ & $\underset{* * *}{0.123}$ & $\underset{* \star *}{0.363}$ & $\underset{* * *}{0.179}$ & $\begin{array}{c}-0.009 \\
*\end{array}$ & $\underset{* \star *}{0.067}$ & $\underset{* * *}{0.408}$ & 0.008 & $\underset{* * *}{-0.36}$ & $\underset{* \star *}{0.172}$ & $\underset{* \star \star}{0.525}$ & $\underset{* * *}{-0.161}$ & $\underset{* * *}{0.388}$ & $\underset{* * *}{-0.493}$ & $\underset{* * *}{-0.042}$ \\
\hline & $\begin{array}{c}\text { Terrain } \\
\text { ruggedness }\end{array}$ & $\underset{* * *}{0.413}$ & $\underset{* * *}{0.091}$ & $\underset{* * \star *}{0.34}$ & $\underset{* * *}{-0.197}$ & $\underset{* * *}{0.091}$ & $\underset{* * *}{0.409}$ & $\underset{* * *}{0.155}$ & $\underset{* * *}{-0.112}$ & $\underset{* * *}{0.182}$ & $\underset{* * *}{0.454}$ & $\underset{* * *}{-0.015}$ & $\underset{* \star *}{-0.364}$ & $\underset{* * *}{0.278}$ & $\underset{* \star *}{0.568}$ & $\underset{* * *}{-0.145}$ & $\underset{* * *}{0.419}$ & $\underset{* \star *}{-0.561}$ & $\underset{* * *}{-0.048}$ \\
\hline & & Heat load & $\underset{*}{0.01}$ & $\underset{* * *}{0.162}$ & $\underset{* * *}{-0.101}$ & $\begin{array}{c}0.067 \\
* * *\end{array}$ & $\underset{* * *}{0.207}$ & $\underset{* * *}{0.027}$ & $\underset{* * *}{-0.031}$ & $\underset{* * *}{0.083}$ & $\underset{* * *}{0.231}$ & 0.007 & $\underset{* * *}{-0.144}$ & $\underset{* \star *}{0.089}$ & $\underset{* * *}{0.251}$ & $\underset{* * *}{-0.057}$ & $\begin{array}{c}0.168 \\
\star \star *\end{array}$ & $\underset{* * *}{-0.222}$ & $\underset{* \star *}{0.014}$ \\
\hline & & & Topsoil pH & $\underset{* * *}{0.361}$ & $\underset{* * *}{0.299}$ & $\underset{* * *}{-0.035}$ & -0.038 & $\underset{* * *}{-0.071}$ & $\underset{* * *}{-0.205}$ & $\underset{* * *}{0.356}$ & $\underset{* \star *}{0.075}$ & $-\underset{* \star * *}{-0.086}$ & $\underset{* \star *}{-0.317}$ & $\underset{* * *}{-0.028}$ & $\underset{* \star *}{-0.059}$ & $-\underset{* * *}{-0.088}$ & $\underset{* * *}{0.075}$ & $\underset{* * *}{0.15}$ & $\underset{* \star *}{0.066}$ \\
\hline & & & & $\begin{array}{l}\text { Limestone } \\
\text { area }\end{array}$ & $\underset{* * *}{0.042}$ & $\underset{* * *}{-0.088}$ & $\underset{* * *}{0.289}$ & $\underset{* * *}{-0.157}$ & $\underset{* * *}{-0.183}$ & $\underset{* * *}{0.097}$ & 0.285 & $\underset{* * *}{0.042}$ & $\underset{* \star \star}{-0.244}$ & $\underset{* * *}{0.075}$ & $\underset{* * *}{0.155}$ & $\underset{* *}{-0.014}$ & $\underset{* * *}{0.131}$ & $\underset{* * *}{-0.116}$ & $\underset{* \star *}{0.053}$ \\
\hline & & & & & $\begin{array}{c}\text { Mean } \\
\text { annual } \\
\text { temperature }\end{array}$ & $\underset{* * *}{-0.412}$ & 0 & $\underset{* * *}{-0.257}$ & $\underset{* * *}{-0.593}$ & $\underset{* * *}{0.672}$ & $\begin{array}{c}0.108 \\
* * *\end{array}$ & $\underset{* * *}{-0.251}$ & $\underset{* \star *}{-0.554}$ & $\underset{* * *}{0.039}$ & $\underset{* * *}{-0.287}$ & $\underset{* * *}{0.142}$ & $\underset{* * *}{0.098}$ & $\underset{* \star *}{0.144}$ & $\underset{* * *}{0.087}$ \\
\hline & & & & & & $\begin{array}{l}\text { Temperature } \\
\text { seasonality }\end{array}$ & $\underset{* * *}{-0.373}$ & $\underset{* * *}{0.557}$ & $\underset{* * *}{0.728}$ & $\underset{* * *}{0.069}$ & $\underset{* * *}{-0.151}$ & $\underset{* * *}{-0.045}$ & $\underset{* \star *}{0.527}$ & $\underset{* * *}{-0.317}$ & 0.205 & $\underset{* * *}{-0.203}$ & $\underset{* * *}{-0.092}$ & $\underset{* * *}{0.132}$ & $\underset{* \star}{-0.014}$ \\
\hline & & & & & & & $\begin{array}{c}\text { Annual } \\
\text { precipitation }\end{array}$ & $\underset{* * *}{-0.373}$ & $\underset{* * *}{-0.331}$ & $\underset{* * *}{-0.063}$ & $\underset{* * *}{0.843}$ & $\underset{* * *}{0.153}$ & $\underset{* \star *}{-0.333}$ & $\underset{* * *}{0.321}$ & $\underset{* * *}{0.196}$ & $\underset{* * *}{0.206}$ & $\underset{* * *}{0.132}$ & $\underset{* * *}{-0.485}$ & $\begin{array}{c}0.02 \\
\star \star *\end{array}$ \\
\hline & & & & & & & & $\begin{array}{l}\text { Precipitation } \\
\text { seasonality }\end{array}$ & $\begin{array}{c}0.469 \\
* \star *\end{array}$ & $\underset{* * *}{0.026}$ & $\underset{* * *}{-0.279}$ & $\underset{* * *}{-0.115}$ & $\underset{* * *}{0.338}$ & $\underset{* * *}{-0.038}$ & $\underset{* * *}{0.034}$ & $\underset{\star * \star *}{-0.169}$ & $\underset{* * *}{0.144}$ & $\underset{* * *}{0.095}$ & $\underset{* * *}{-0.291}$ \\
\hline & & & & & & & & & $\begin{array}{l}\text { Summer } \\
\text { rainfall }\end{array}$ & $\underset{* * *}{-0.281}$ & $\underset{* \star *}{-0.164}$ & $\begin{array}{c}0.007 \\
.\end{array}$ & $\underset{* * *}{0.694}$ & $\underset{* * *}{-0.431}$ & 0.086 & $\underset{* * *}{-0.126}$ & $\underset{* * *}{-0.274}$ & $\underset{* * *}{0.216}$ & -0.008 \\
\hline & & & & & & & & & & $\begin{array}{c}\text { Annual } \\
\text { potential } \\
\text { evapotransp. }\end{array}$ & $\underset{* \star \star}{0.295}$ & $\underset{* \star *}{-0.356}$ & $\underset{* \star *}{-0.619}$ & $\underset{* * *}{-0.07}$ & $\underset{* * *}{0.024}$ & $\underset{* * *}{-0.019}$ & $\underset{* * *}{0.232}$ & $\underset{* \star *}{0.029}$ & $\underset{* * *}{0.171}$ \\
\hline & & & & & & & & & & & $\begin{array}{l}\text { Annual } \\
\text { actual } \\
\text { vapotransp. }\end{array}$ & $\underset{* \star *}{-0.024}$ & $\underset{* \star \star}{-0.432}$ & $\underset{* * *}{0.142}$ & $\begin{array}{c}0.281 \\
\star * *\end{array}$ & $\underset{* * *}{0.134}$ & $\underset{* * *}{0.121}$ & $\underset{* * *}{-0.389}$ & $\begin{array}{c}0.132 \\
* * *\end{array}$ \\
\hline & & & & & & & & & & & & $\begin{array}{l}\text { Presence/ } \\
\text { absence } \\
\text { of } L \text { LGM } \\
\text { glacier }\end{array}$ & $\underset{* * *}{0.209}$ & $\underset{* * *}{0.322}$ & $\underset{* * *}{-0.089}$ & $\begin{array}{c}-0.009 \\
*\end{array}$ & $\underset{* * *}{-0.112}$ & 0.007 & $\underset{* \star *}{-0.094}$ \\
\hline & & & & & & & & & & & & & \begin{tabular}{|c} 
Temperature \\
change \\
since \\
LGM
\end{tabular} & $\underset{* * *}{-0.14}$ & $\underset{* * *}{-0.11}$ & $\underset{* * *}{-0.029}$ & $\underset{* * *}{-0.329}$ & $\underset{* * *}{0.244}$ & $\underset{* * *}{-0.179}$ \\
\hline & & & & & & & & & & & & & & $\begin{array}{l}\text { Precipitation } \\
\text { change } \\
\text { since } \\
\text { LGM }\end{array}$ & $\underset{* * *}{-0.035}$ & $\underset{* \star *}{0.113}$ & $\underset{* * *}{0.232}$ & $\underset{* * *}{-0.289}$ & $\underset{* * *}{-0.193}$ \\
\hline & & & & & & & & & & & & & & & $\begin{array}{l}\text { Forest } \\
\text { area }\end{array}$ & $\underset{* * *}{-0.442}$ & $\underset{* * *}{0.195}$ & $\underset{* * *}{-0.519}$ & $\underset{* \star *}{0.117}$ \\
\hline & & & & & & & & & & & & & & & & $\begin{array}{c}\text { Mosaic } \\
\text { land } \\
\text { area }\end{array}$ & $\underset{* * *}{-0.084}$ & $\underset{* * *}{-0.148}$ & $\underset{* * *}{0.051}$ \\
\hline & & & & & & & & & & & & & & & & & $\begin{array}{c}\text { Shrubland } \\
\text { area }\end{array}$ & $\underset{* \star *}{-0.393}$ & $\underset{* * *}{-0.041}$ \\
\hline & & & & & & & & & & & & & & & & & & $\begin{array}{l}\text { Intensively } \\
\text { cultivated } \\
\text { land } \\
\text { area }\end{array}$ & $\underset{* * *}{-0.026}$ \\
\hline & $=$ & $=$ & $\square$ & 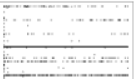 & $=$ & 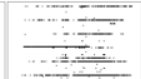 & $\square$ & $\equiv$ & 3 & \pm & $=$ & & 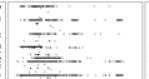 & 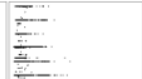 & & $=$ & 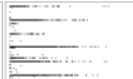 & $\square$ & lot \\
\hline & $=$ & 1 & 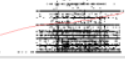 & 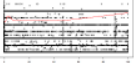 & 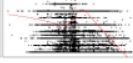 & \pm & 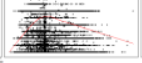 & & 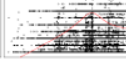 & 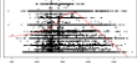 & 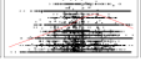 & & 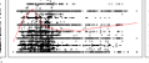 & $E$ & Li & 1 & $=$ & $=$ & \\
\hline
\end{tabular}

Figure S1.5 - Matrix of correlations between predictors in the dataset of deciduous broadleaf forests. Upper triangle: Spearman's correlation coefficients and their significance (p-value '.' $\geq 0.05$ and $<0.1$; $^{(*)} \geq 0.01$ and $<0.05$; $^{* * *} \geq 0.001$ and $<0.01$; $^{(* * *)}<0.001$ ); lower triangle: scatter plots for pairs of predictors. 


\begin{tabular}{|c|c|c|c|c|c|c|c|c|c|c|c|c|c|c|c|c|c|c|c|}
\hline Elevation & $\underset{* * *}{0.848}$ & $\underset{* * *}{0.338}$ & $\underset{* * *}{0.208}$ & $\underset{* \star *}{0.418}$ & $\underset{* * \star}{-0.716}$ & $\underset{* * *}{-0.238}$ & $\underset{* \star *}{0.677}$ & -0.008 & $\underset{* *}{0.024}$ & $\underset{* * *}{-0.305}$ & $\underset{* * *}{0.342}$ & $\underset{* * *}{0.263}$ & $\underset{* * *}{-0.529}$ & $\underset{* \star *}{0.26}$ & $\underset{* \star \star}{0.126}$ & 0.003 & $\begin{array}{c}0.33 \\
* * *\end{array}$ & $\underset{* * *}{-0.528}$ & $\underset{* * *}{0.135}$ \\
\hline & $\begin{array}{c}\text { Terrain } \\
\text { ruggedness }\end{array}$ & $\underset{* * *}{0.394}$ & $\underset{* \star *}{0.307}$ & $\underset{* * \star}{0.537}$ & $\underset{* \star \star}{-0.506}$ & $\underset{* * *}{-0.22}$ & $\underset{* \star *}{0.648}$ & $\underset{* *}{0.021}$ & -0.012 & $\underset{* * *}{-0.137}$ & $\begin{array}{l}0.4 \\
* * *\end{array}$ & $\underset{* * *}{0.223}$ & $\underset{* * *}{-0.551}$ & $\underset{* * *}{0.298}$ & $\underset{* * \star}{0.152}$ & $\begin{array}{c}-0.017 \\
*\end{array}$ & $\begin{array}{c}0.29 \\
* * *\end{array}$ & $\underset{* * *}{-0.474}$ & $\underset{* * *}{0.101}$ \\
\hline & & Heat load & $\underset{* * *}{0.136}$ & $\underset{* * *}{0.172}$ & $\underset{* * *}{-0.248}$ & $\underset{* * *}{-0.099}$ & $\underset{* * *}{0.226}$ & -0.008 & $\underset{* * \star}{-0.038}$ & $\underset{* * *}{-0.116}$ & $\underset{* * *}{0.083}$ & $\underset{* * *}{0.089}$ & $\underset{* * *}{-0.228}$ & $\begin{array}{c}0.169 \\
\star * *\end{array}$ & $\underset{* * *}{0.032}$ & $\underset{* * *}{-0.051}$ & $\underset{* * *}{0.155}$ & $\underset{* * *}{-0.143}$ & $\underset{* * *}{0.054}$ \\
\hline & 5 & & Topsoil pH & $\underset{* * \star}{0.473}$ & $\underset{* * *}{0.067}$ & $\underset{* * *}{-0.047}$ & $\underset{* * \star}{0.144}$ & $\underset{* * *}{0.095}$ & $\underset{* * *}{-0.091}$ & $\underset{* * *}{0.244}$ & $\underset{* * *}{0.208}$ & $\underset{* * *}{0.077}$ & $\underset{* * *}{-0.293}$ & $\underset{* * *}{0.133}$ & $\underset{* * *}{-0.087}$ & $\underset{* * *}{0.045}$ & $\underset{* *}{0.024}$ & $\underset{* * *}{-0.075}$ & $\underset{* * *}{0.036}$ \\
\hline & 翟 & & $\begin{array}{r} \\
8 \\
\end{array}$ & $\begin{array}{l}\text { Limestone } \\
\text { area }\end{array}$ & $\underset{* * *}{-0.104}$ & $\underset{* * *}{-0.174}$ & $\underset{* \star \star}{0.413}$ & $\underset{* * *}{-0.065}$ & $\underset{* \star *}{-0.161}$ & $\underset{* * *}{0.104}$ & $\underset{* \star *}{0.375}$ & $\underset{* * \star}{0.187}$ & $\underset{* * *}{-0.452}$ & $\underset{* \star *}{0.111}$ & $\underset{* \star *}{0.055}$ & $\underset{* \star *}{0.047}$ & $\underset{* \star *}{0.123}$ & $\begin{array}{c}-0.25 \\
* * *\end{array}$ & $\underset{* * *}{0.084}$ \\
\hline & & & & & $\begin{array}{c}\text { Mean } \\
\text { annual } \\
\text { temperature }\end{array}$ & $\underset{* * *}{-0.104}$ & $\underset{* * *}{-0.451}$ & $\underset{* * *}{-0.103}$ & $\begin{array}{c}-0.32 \\
* \star *\end{array}$ & $\underset{* * *}{0.701}$ & $\begin{array}{c}-0.013 \\
.\end{array}$ & $\underset{* * *}{-0.313}$ & -0.069 & $\underset{* * *}{-0.175}$ & $\underset{* * *}{-0.186}$ & $\underset{* * *}{0.059}$ & -0.25 & $\underset{* * *}{0.406}$ & $\underset{* * *}{-0.113}$ \\
\hline & & & & & & $\begin{array}{l}\text { Temperature } \\
\text { seasonality }\end{array}$ & $\underset{* * *}{-0.418}$ & $\underset{* * *}{0.565}$ & $\begin{array}{c}0.617 \\
* * *\end{array}$ & $\begin{array}{c}0.196 \\
* \star *\end{array}$ & $\underset{* * *}{-0.065}$ & $\underset{* * *}{-0.071}$ & $\underset{* * *}{0.572}$ & $\underset{* * *}{-0.38}$ & $\underset{* * *}{0.236}$ & $\underset{* * *}{-0.15}$ & $\begin{array}{l}-0.25 \\
\star * *\end{array}$ & $\underset{* * *}{0.23}$ & $\underset{*}{-0.019}$ \\
\hline & & & & & & & $\begin{array}{c}\text { Annual } \\
\text { precipitation }\end{array}$ & $\underset{* * *}{-0.333}$ & $\underset{* * *}{-0.188}$ & $\underset{* * *}{-0.256}$ & $\underset{* * *}{0.634}$ & $\underset{* * *}{0.293}$ & $\underset{* * *}{-0.518}$ & $\underset{* * *}{0.344}$ & 0.008 & $\underset{* * *}{0.176}$ & $\underset{* \star * \star}{0.128}$ & $\underset{* * *}{-0.513}$ & $\begin{array}{c}0.03 \\
* * *\end{array}$ \\
\hline & & & & & & & & $\begin{array}{l}\text { Precipitation } \\
\text { seasonality }\end{array}$ & $\underset{* * *}{0.75}$ & $\underset{* \star *}{0.172}$ & $\underset{* \star *}{-0.053}$ & $\underset{* * *}{-0.164}$ & $\underset{* * *}{0.323}$ & $\underset{* * *}{-0.212}$ & $\underset{* * *}{-0.042}$ & $\begin{array}{c}-0.06 \\
* * *\end{array}$ & $\begin{array}{c}0.04 \\
* * *\end{array}$ & $\underset{* * *}{0.134}$ & $-\underset{* * *}{-0.028}$ \\
\hline & & & & & & & & & $\begin{array}{l}\text { Summer } \\
\text { rainfall }\end{array}$ & $\underset{* * *}{-0.049}$ & $\underset{* * \star}{0.043}$ & $\underset{* * *}{-0.04}$ & $\underset{* * *}{0.511}$ & $\underset{* * *}{-0.318}$ & $\underset{* * *}{0.029}$ & 0.009 & $\underset{* * *}{-0.143}$ & $\underset{* * *}{0.146}$ & -0.013 \\
\hline & & & & & & & & & & $\begin{array}{c}\begin{array}{c}\text { Annual } \\
\text { potential } \\
\text { evapotransp. }\end{array}\end{array}$ & $\underbrace{0.392}_{* \star *}$ & $\underset{* * *}{-0.327}$ & $\underset{* * *}{-0.311}$ & $\underset{* * *}{-0.349}$ & $\underset{* * *}{-0.096}$ & $\underset{* * *}{0.087}$ & $\underset{* * *}{-0.238}$ & $\underset{* * *}{0.275}$ & -0.017 \\
\hline & & & & & & & & & & & $\begin{array}{c}\text { Annual } \\
\text { actual } \\
\text { evapotransp. }\end{array}$ & $\underset{* * *}{0.038}$ & $\underset{* * *}{-0.521}$ & $\underset{* * *}{-0.061}$ & $\underset{* * *}{0.091}$ & $\underset{* * *}{0.16}$ & $\underset{* \star *}{-0.119}$ & $\underset{* \star *}{-0.263}$ & $\underset{* *}{0.023}$ \\
\hline & & & & & & & & & & & & $\begin{array}{l}\text { Presence/ } \\
\text { absence } \\
\text { of } L G M \\
\text { glacier }\end{array}$ & $\underset{* * *}{-0.061}$ & $\underset{* \star *}{0.322}$ & $\underset{* *}{0.02}$ & 0.014 & $\underset{* * *}{-0.101}$ & $\underset{* * *}{-0.183}$ & $\underset{* * *}{-0.028}$ \\
\hline & & & & -1 & & & 8 & & & & & & \begin{tabular}{|c} 
Temperature \\
change \\
since \\
LGM
\end{tabular} & $\underset{* * *}{-0.133}$ & $\underset{* * *}{0.054}$ & $\underset{* * *}{-0.116}$ & $\underset{* * *}{-0.126}$ & $\underset{* * *}{0.301}$ & $\underset{* * *}{-0.092}$ \\
\hline & & & & & & & & & & & & & & $\begin{array}{l}\text { Precipitation } \\
\text { change } \\
\text { since } \\
\text { LGM }\end{array}$ & $\underset{* * *}{-0.07}$ & $\underset{* \star *}{0.065}$ & $\underset{* * *}{0.161}$ & $\underset{* \star *}{-0.236}$ & $\underset{*}{-0.016}$ \\
\hline & & & & & & & & & & & & & & & $\begin{array}{l}\text { Forest } \\
\text { area }\end{array}$ & $\underset{* * *}{-0.506}$ & -0.009 & $\underset{* * *}{-0.291}$ & $\begin{array}{c}0.16 \\
* * *\end{array}$ \\
\hline & & & & & & & & & & & & & & & & $\begin{array}{l}\text { Mosaic } \\
\text { land } \\
\text { area }\end{array}$ & $\underset{* * *}{-0.241}$ & $\underset{* \star *}{-0.032}$ & $-\underset{* * *}{-0.058}$ \\
\hline & & & 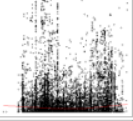 & & & & & & & & & & & & & & $\begin{array}{c}\text { Shrubland } \\
\text { area }\end{array}$ & $\underset{* * *}{-0.314}$ & $\underset{* * *}{0.043}$ \\
\hline & & & 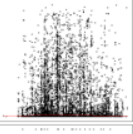 & 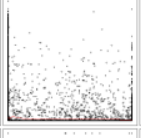 & & Was & & 7) & & & & & W & L. & & & & $\begin{array}{l}\text { Intensively } \\
\text { cultivated } \\
\text { land } \\
\text { area }\end{array}$ & $\underset{* * *}{-0.052}$ \\
\hline$=$ & $\frac{\square}{\square}$ & & 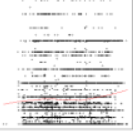 & 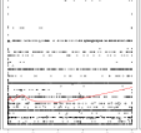 & $\frac{8}{\sqrt{n}}$ & 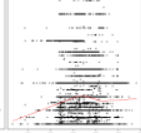 & $\square$ & $=$ & $\frac{-}{\sqrt{n}}$ & $\frac{\square}{\square}$ & $\frac{\square}{1+}$ & & 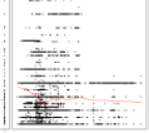 & $\frac{-}{ \pm}$ & 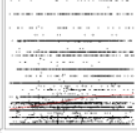 & $=$ & 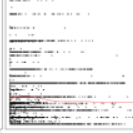 & 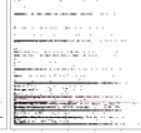 & $\begin{array}{l}\text { Plot } \\
\text { size }\end{array}$ \\
\hline
\end{tabular}

Figure S1.6 - Matrix of correlations between predictors in the dataset of coniferous forests. Upper triangle: Spearman's correlation coefficients and their significance (p-value '.' $\geq 0.05$ and $<0.1$; '*’ $\geq 0.01$ and $<0.05$; $^{* * *} \geq 0.001$ and $\left.<0.01 ;{ }^{\prime * * *}>0.001\right)$; lower triangle: scatter plots for pairs of predictors. 


\begin{tabular}{|c|c|c|c|c|c|c|c|c|c|c|c|c|c|c|c|c|c|c|c|}
\hline Elevation & $\underset{* * *}{0.557}$ & $\underset{* * *}{0.186}$ & $\underset{* * *}{0.084}$ & $\begin{array}{c}0.17 \\
* * *\end{array}$ & $\underset{* * *}{-0.643}$ & $\underset{* * *}{0.278}$ & $\begin{array}{c}-0.1 \\
* * *\end{array}$ & $\begin{array}{c}0.08 \\
* * *\end{array}$ & $\underset{* * *}{-0.079}$ & $\underset{* * *}{-0.254}$ & $\underset{* * *}{-0.208}$ & 0.01 & $\underset{* * *}{-0.399}$ & $\underset{* * *}{0.235}$ & $\begin{array}{c}0.34 \\
* * *\end{array}$ & $\underset{* * *}{0.11}$ & $\underset{* * *}{0.335}$ & $\underset{* * *}{-0.138}$ & $\underset{*}{-0.05}$ \\
\hline & $\begin{array}{c}\text { Terrain } \\
\text { ruggedness }\end{array}$ & $\underset{* * *}{0.082}$ & $\underset{* *}{-0.056}$ & $\underset{* * *}{0.122}$ & $\underset{* \star *}{-0.37}$ & -0.018 & $\underset{* * *}{0.098}$ & -0.032 & $\begin{array}{c}0.032 \\
.\end{array}$ & $\underset{* * *}{-0.289}$ & -0.017 & $\underset{* * *}{0.066}$ & $\underset{* * *}{-0.273}$ & $\underset{* \star *}{0.087}$ & $\underset{* * *}{0.369}$ & 0.013 & $\underset{* * *}{0.372}$ & $\underset{* * *}{-0.405}$ & $\begin{array}{c}0.034 \\
.\end{array}$ \\
\hline & 6 & Heat load & 0.027 & -0.03 & $\underset{* * \star}{-0.133}$ & 0.001 & $\underset{* * *}{0.073}$ & 0.024 & -0.018 & $\underset{* * *}{-0.139}$ & 0.025 & $\underset{* * *}{0.086}$ & $\underset{*}{-0.049}$ & $\underset{* * *}{0.098}$ & $\underset{* * *}{0.097}$ & -0.018 & $\underset{* *}{0.058}$ & $\begin{array}{c}0.033 \\
.\end{array}$ & $\underset{* *}{-0.051}$ \\
\hline & 6 & 1 & Topsoil pH & $\underset{* * *}{0.09}$ & $\underset{* *}{-0.056}$ & $\underset{* * \star}{0.228}$ & $\underset{* * *}{-0.178}$ & -0.001 & 0.036 & -0.018 & $\underset{* * *}{-0.178}$ & $\begin{array}{c}0.035 \\
.\end{array}$ & $\begin{array}{c}-0.038 \\
.\end{array}$ & $\underset{* *}{0.052}$ & $\underset{\star * \star}{-0.074}$ & -0.014 & $\underset{* *}{0.062}$ & $\underset{* * *}{0.183}$ & $\underset{* * *}{-0.071}$ \\
\hline & & & & $\begin{array}{c}\text { Limestone } \\
\text { area }\end{array}$ & $\begin{array}{c}-0.29 \\
\star \star \star *\end{array}$ & $\underset{* \star *}{0.376}$ & $\underset{* * *}{0.194}$ & $\underset{* * *}{-0.23}$ & $\underset{* \star *}{0.194}$ & 0.014 & $\underset{* * *}{0.235}$ & $\begin{array}{c}0.09 \\
* \star *\end{array}$ & $\underset{* \star *}{0.235}$ & $\begin{array}{c}0.04 \\
*\end{array}$ & $\underset{* *}{0.051}$ & $\underset{* * *}{0.233}$ & $\underset{* * *}{-0.065}$ & $\underset{* *}{0.053}$ & $\underset{* * *}{0.093}$ \\
\hline & 8 & \% & & & $\begin{array}{c}\text { Mean } \\
\text { annual } \\
\text { temperature }\end{array}$ & $\underset{* * *}{-0.356}$ & $\underset{* * *}{-0.332}$ & $\underset{* * *}{0.552}$ & $\underset{* * *}{-0.521}$ & $\underset{* * *}{0.455}$ & $\begin{array}{c}-0.3 \\
* * *\end{array}$ & $\underset{* * *}{-0.116}$ & $\underset{*}{-0.046}$ & $\underset{* *}{0.058}$ & $\underset{* * *}{-0.463}$ & $\underset{* * *}{-0.069}$ & $\underset{* * *}{-0.097}$ & $\underset{* * *}{0.357}$ & $\underset{* * *}{-0.114}$ \\
\hline & 湜 & \% & & & & $\begin{array}{l}\text { Temperature } \\
\text { seasonality }\end{array}$ & $\underset{* * *}{0.091}$ & $\underset{* * *}{-0.326}$ & $\underset{* * *}{0.333}$ & $\underset{* * *}{0.239}$ & $\begin{array}{c}0.18 \\
* * *\end{array}$ & $\underset{* * *}{0.134}$ & $\begin{array}{c}0.49 \\
* * *\end{array}$ & $\underset{* * *}{0.108}$ & $\underset{* * *}{0.136}$ & $\underset{* * *}{0.08}$ & $\underset{* * *}{-0.127}$ & $\underset{* *}{0.059}$ & $\underset{* *}{0.057}$ \\
\hline & & 8 & & & 4 & & $\begin{array}{c}\text { Annual } \\
\text { precipitation }\end{array}$ & $\underset{* \star *}{-0.441}$ & $\underset{* \star *}{0.386}$ & $\underset{* \star *}{-0.15}$ & $\underset{* * *}{0.924}$ & $\underset{* \star *}{0.069}$ & $\underset{* * *}{0.383}$ & $\underset{* \star *}{0.119}$ & $\underset{* * *}{0.182}$ & $\underset{* * *}{0.134}$ & $\underset{* * *}{-0.263}$ & $\underset{* * *}{-0.238}$ & $\underset{* * *}{0.098}$ \\
\hline & & & & & & & & $\begin{array}{l}\text { Precipitation } \\
\text { seasonality }\end{array}$ & $\underset{* * *}{-0.981}$ & $\underset{* * *}{0.26}$ & $\underset{* * *}{-0.584}$ & $\underset{* * *}{-0.104}$ & $\underset{* \star *}{-0.465}$ & $\underset{* * *}{0.214}$ & $\underset{* * *}{-0.351}$ & -0.016 & $\underset{* * *}{0.256}$ & $\underset{* * *}{0.236}$ & $\underset{* * *}{-0.153}$ \\
\hline & & & & & & & & & $\begin{array}{l}\text { Summer } \\
\text { rainfall }\end{array}$ & $\underset{* * *}{-0.21}$ & $\underset{* * *}{0.544}$ & $\underset{* * *}{0.134}$ & $\underset{* * *}{0.43}$ & $\underset{* * *}{-0.192}$ & $\underset{* * *}{0.331}$ & 0.007 & $\underset{* * *}{-0.232}$ & $\underset{* * *}{-0.222}$ & $\underset{* * *}{0.125}$ \\
\hline & 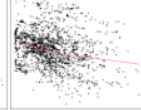 & & & & & & & & & $\begin{array}{c}\text { Annual } \\
\text { potential } \\
\text { evapotransp. }\end{array}$ & -0.007 & -0.022 & $\underset{* * *}{0.153}$ & $\underset{* * *}{0.124}$ & $\underset{* * *}{-0.231}$ & -0.011 & -0.088 & $\begin{array}{c}0.377 \\
* \star *\end{array}$ & 0.019 \\
\hline & & 5 & & & & & & & a & 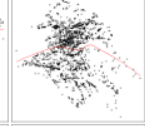 & $\begin{array}{c}\text { Annual } \\
\text { actual } \\
\text { evapotransp. }\end{array}$ & $\underset{* * *}{0.119}$ & $\begin{array}{l}0.5 \\
* * *\end{array}$ & 0.021 & $\underset{* * *}{0.166}$ & $\underset{* * *}{0.104}$ & $\underset{* * *}{-0.312}$ & $\underset{* * *}{-0.168}$ & $\underset{* * *}{0.116}$ \\
\hline & & & & & & & & & & & & $\begin{array}{l}\text { Presence/ } \\
\text { absence } \\
\text { of } L G M \\
\text { glacier }\end{array}$ & $\underset{* * *}{0.128}$ & $\underset{* * *}{-0.133}$ & 0.017 & 0.009 & $-\underset{* *}{0.056}$ & -0.011 & $-\underset{* *}{0.058}$ \\
\hline & & 3 & & & & & & & & & & & \begin{tabular}{|c} 
Temperature \\
change \\
since \\
LGM
\end{tabular} & $\underset{* * *}{-0.277}$ & $\underset{* *}{0.054}$ & 0.014 & $\underset{* * *}{-0.404}$ & 0.034 & $\underset{* * *}{0.268}$ \\
\hline 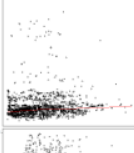 & we & 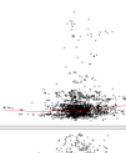 & thatede & Fonsting & $\Rightarrow$ & -1 & 1 & $d$ & + & 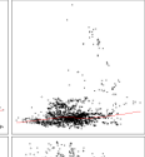 & -40 & & - & $\begin{array}{l}\text { Precipitation } \\
\text { changee } \\
\text { since } \\
\text { LGM }\end{array}$ & -0.016 & 0.005 & 0.025 & $\underset{* * \star}{0.093}$ & $\underset{* * *}{-0.21}$ \\
\hline & & & & & & & & & & & 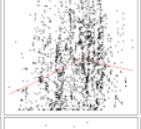 & & & 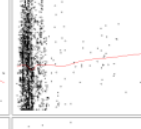 & $\begin{array}{c}\text { Forest } \\
\text { area }\end{array}$ & $\underset{* \star *}{-0.202}$ & $\underset{* * *}{-0.15}$ & $\underset{* * *}{-0.34}$ & $\underset{* * *}{0.08}$ \\
\hline & 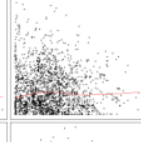 & t & & & 2. & & & al & 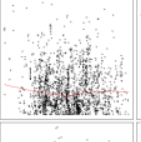 & a & , & & $y=$ & 1 & $x_{2}$ & $\begin{array}{l}\text { Mosaic } \\
\text { land } \\
\text { area }\end{array}$ & $\underset{* * *}{-0.082}$ & $\underset{* \star *}{0.104}$ & -0.027 \\
\hline & & 1 & W & & y) & (1) & & ind & rylu & 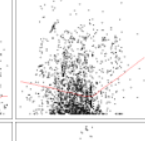 & I & & 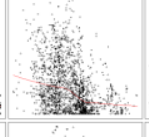 & in & & z & $\begin{array}{c}\text { Shrubland } \\
\text { area }\end{array}$ & $\underset{* \star *}{-0.294}$ & -0.017 \\
\hline & 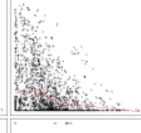 & 4 & 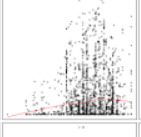 & & sals. & $\begin{array}{r}6 \\
-31 \\
\end{array}$ & a & neste & Wasur & 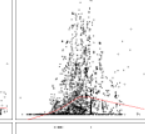 & 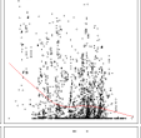 & & Sax & I & & 20 & W. & \begin{tabular}{|l} 
Intensively \\
cultivated \\
land \\
area \\
\end{tabular} & $\underset{* * *}{-0.118}$ \\
\hline 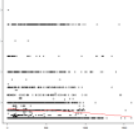 & 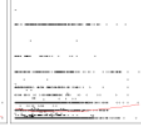 & 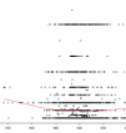 & 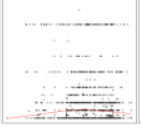 & & $\square$ & 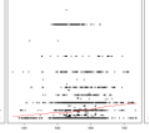 & $\frac{-}{\square}$ & $\begin{array}{l}- \\
- \\
\square\end{array}$ & $\frac{-1}{-1}$ & $\square$ & $\begin{array}{r}\square \\
\square\end{array}$ & & $\square$ & 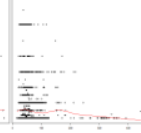 & 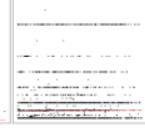 & $\begin{array}{c}\square \\
\square \\
\square \\
\end{array}$ & $\begin{array}{l}+ \\
\vdots \\
\end{array}$ & 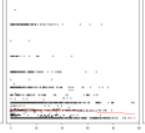 & $\begin{array}{l}\text { Plot } \\
\text { size }\end{array}$ \\
\hline
\end{tabular}

Figure S1.7 - Matrix of correlations between predictors in the dataset of sclerophyllous forests. Upper triangle: Spearman's correlation coefficients and their significance (p-value '.' $\geq 0.05$ and $<0.1$; '*’ $\geq 0.01$ and $<0.05$; $^{* * *} \geq 0.001$ and $\left.<0.01 ;{ }^{\prime * * *}>0.001\right)$; lower triangle: scatter plots for pairs of predictors. 


\section{Random forests - model fitting and relative importance measures}

While fitting a Random Forest model, 500 bootstrap samples of the data, each containing 2/3 of plots in the dataset, were selected, and regression trees were grown on them. The remaining 1/3 constituted the out-of-bag (OOB) portion of the data, which were used to test the predictive power of the tree. Each regression tree was grown using $m$ randomly selected variables to avoid high correlation among trees. To select the most appropriate $m$ value, we tested the predictive power of the models with different settings of $m$ (from 1 to 20), running each model ten times. These tests confirmed that default settings ( $m=1 / 3$ of explanatory variables) performed best in most cases. Therefore, we used the default setting of $m=6$. The relative importance of predictors within Random Forest models is expressed by two measures. The first, called 'Mean decrease in accuracy', quantifies how much randomization of the target explanatory variable decreases the accuracy of the model, i.e., increases the mean of squared prediction errors (MSE) estimated from OOB data. The more randomization decreases the accuracy of the model, the more important the variable. We used 10 permutations of each variable in each model run. The second measure, called 'Mean decrease in node impurity', quantifies the strength of a particular predictor in terms of the decrease in residual sum of squares (RSS) between the non-split and split bulk of observations, which is averaged over all node splits and all regression trees. The relative importance of predictors was measured in 10 runs and then averaged.

\section{Resampling procedure to reduce local oversampling}

The resampling procedure uses criteria combining spatial distance among plots and their similarity in species composition. For this purpose, species nomenclature across the dataset was unified according to the SynBioSys species list (Chytrý et al., 2016) and the expert system for classification of European forests (Schaminée et al., 2014). The similarity in species composition between each pair of plots was measured using the $\beta_{\text {sim }}$ index, which is independent of differences in species richness (Koleff, Gaston, \& Lennon, 2003). The following criteria were used: if two plots were situated closer than $5642 \mathrm{~m}$ (diameter of circular buffer zones used for calculation of environmental variables), and their compositional similarity was 0.8 or higher, then one plot from the pair was selected. If more than two plots were close to each other, the algorithm started from the pair that was most similar in species composition.

We did two variants of the resampling: (i) selecting the richer plot, and (ii) selecting a random plot, both from pairs of plots similar in species composition and located close to each other. 


\section{Appendix 2 - SUPPLEMENTARY RESULTS}

Examples of fine-scale alpha-diversity maps in zoomed windows

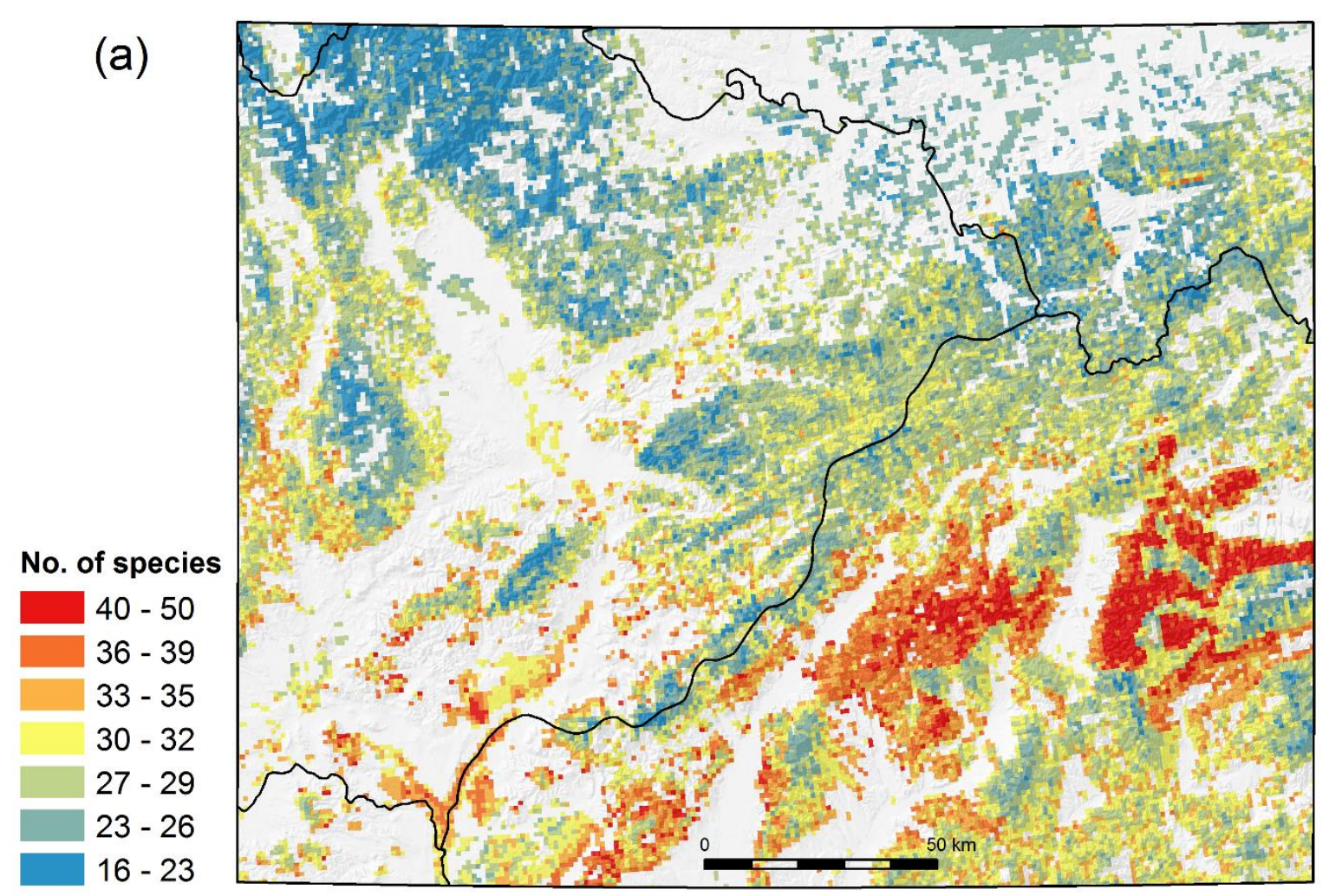

(b)
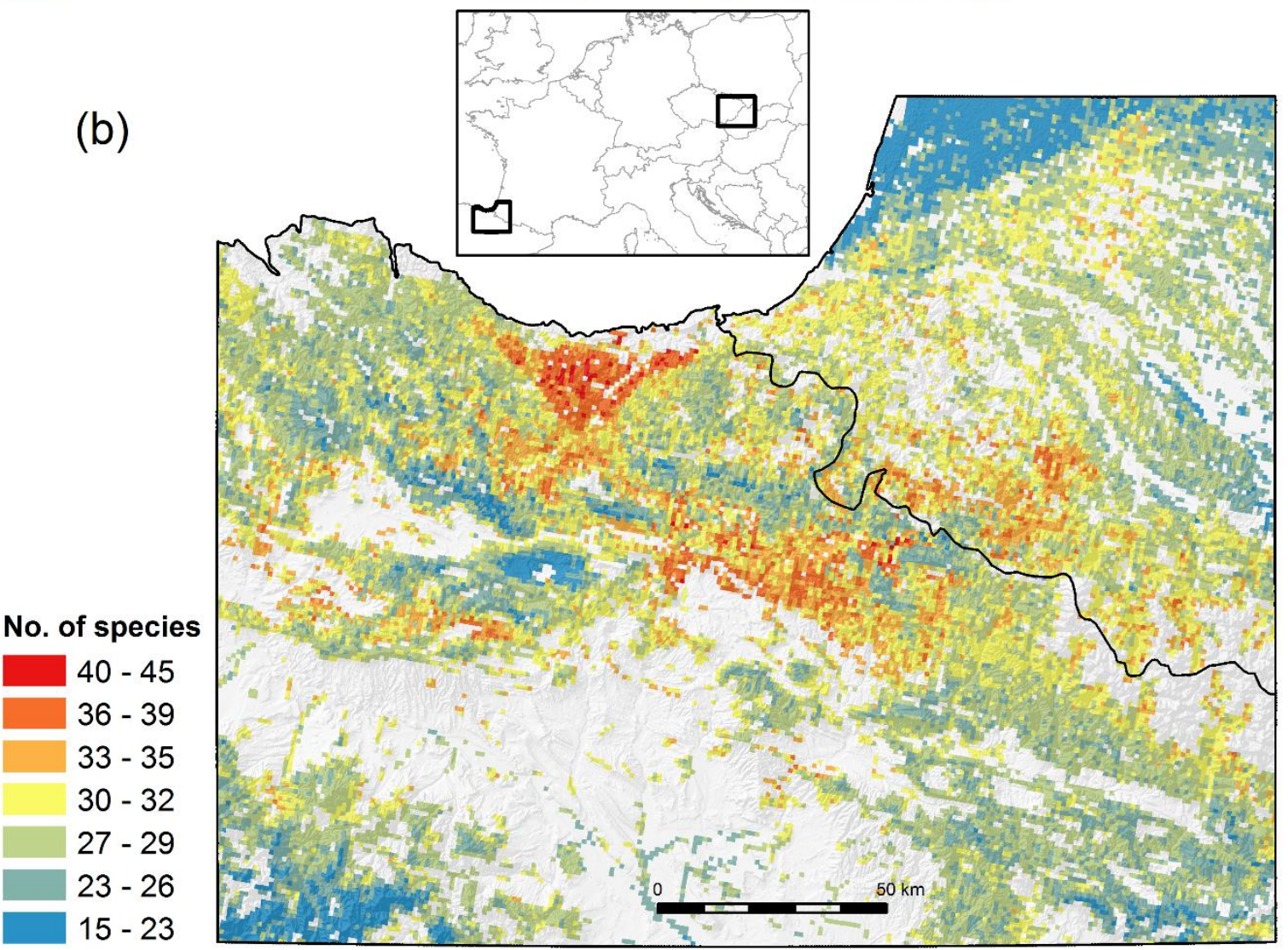

Figure S2.8 - Predicted alpha diversity of vascular plants in forests (for a plot size of $400 \mathrm{~m}^{2}$ ) in a spatial resolution of $1 \times 1 \mathrm{~km}$ based on the pan-European Random Forest model for all forests displayed for two selected areas: (a) borderlands of the Czech Republic and Slovakia, and (b) north-western borderlands of Spain and France. 
Spatial correlograms

500 random windows for all forest types

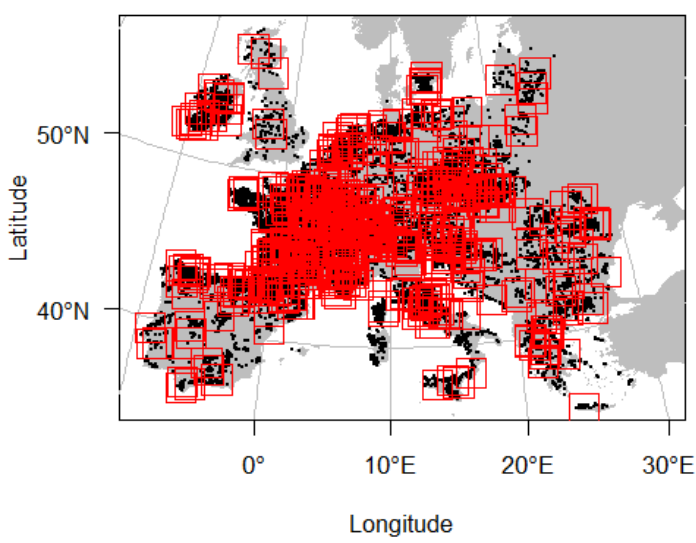

Predicted alpha diversity

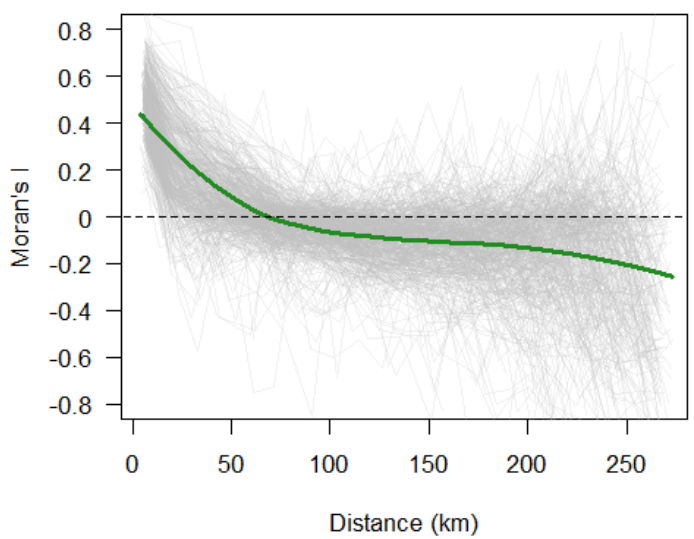

Observed alpha diversity

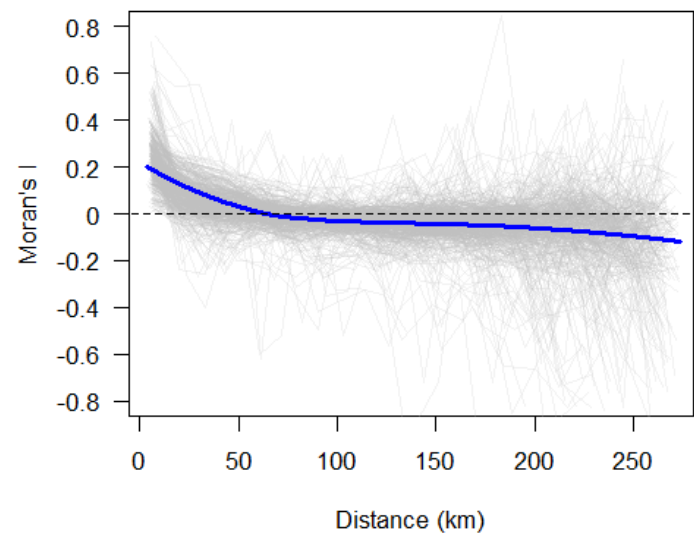

Residual alpha diversity

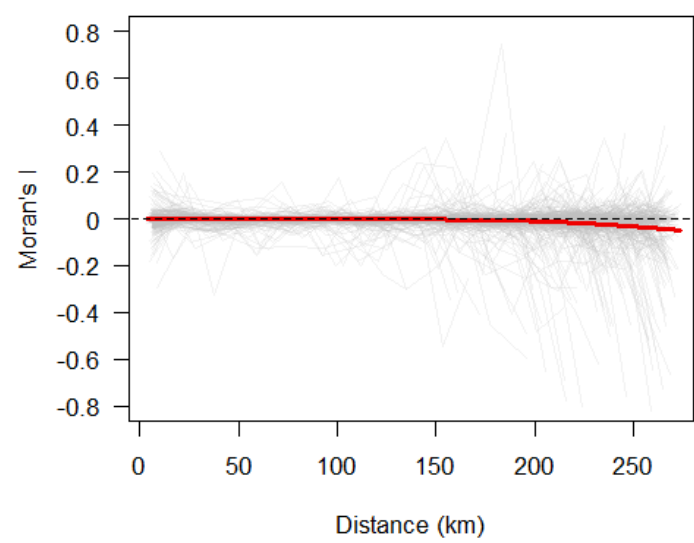

Figure S2.9 - Spatial correlograms of the residual, observed, and predicted alpha diversity for all forests, calculated within 500 rectangular windows (a side length of $200 \mathrm{~km}$ ), randomly distributed across the sampled regions in Europe. 

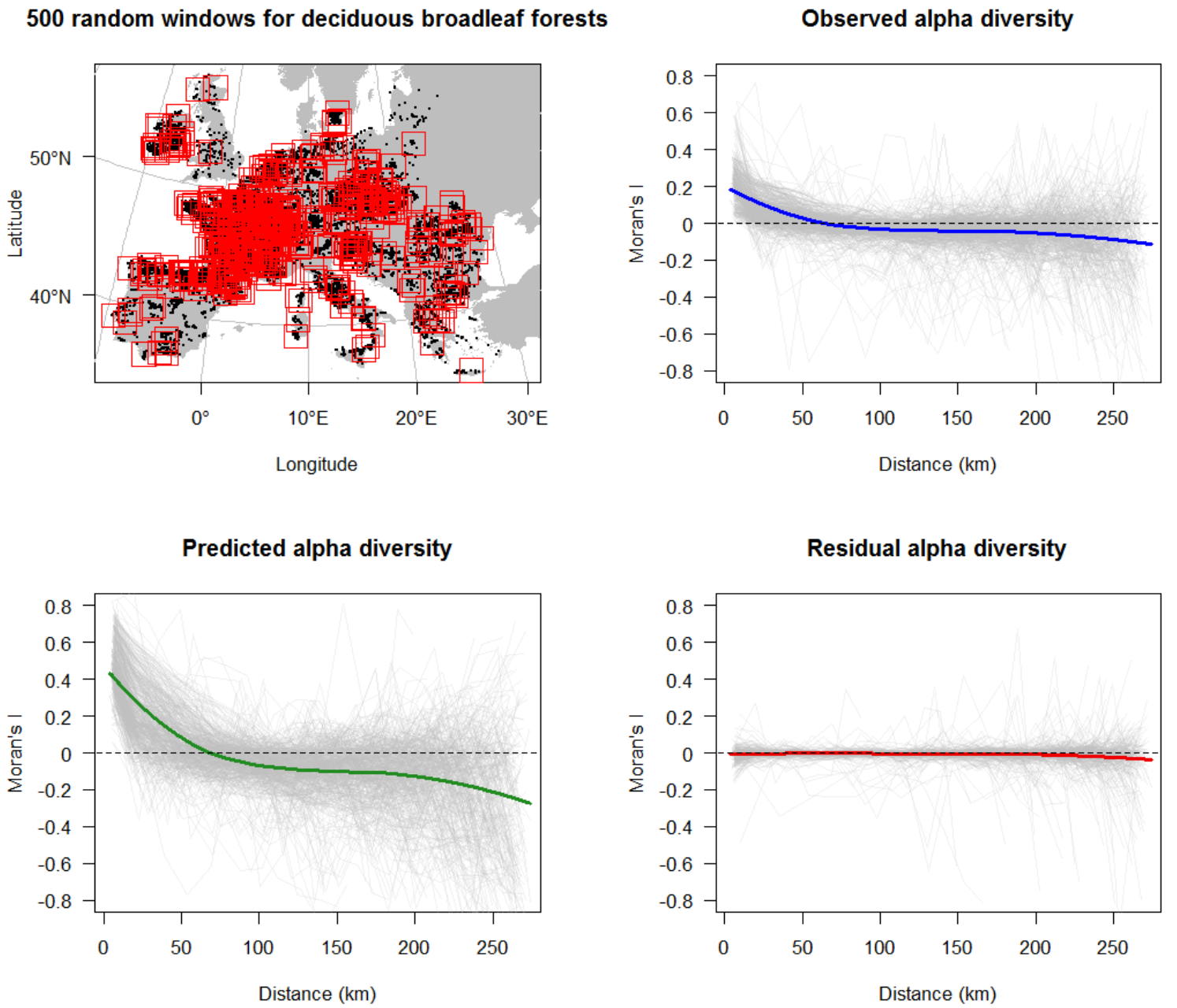

Figure S2.10 - Spatial correlograms of the residual, observed, and predicted alpha diversity for deciduous broadleaf forests, calculated within 500 rectangular windows (a side length of $200 \mathrm{~km}$ ), randomly distributed across the sampled regions in Europe. 
500 random windows for coniferous forests

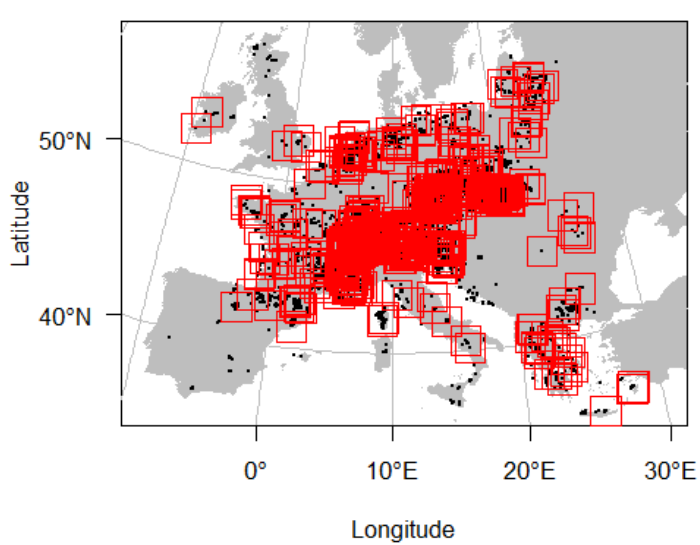

Predicted alpha diversity

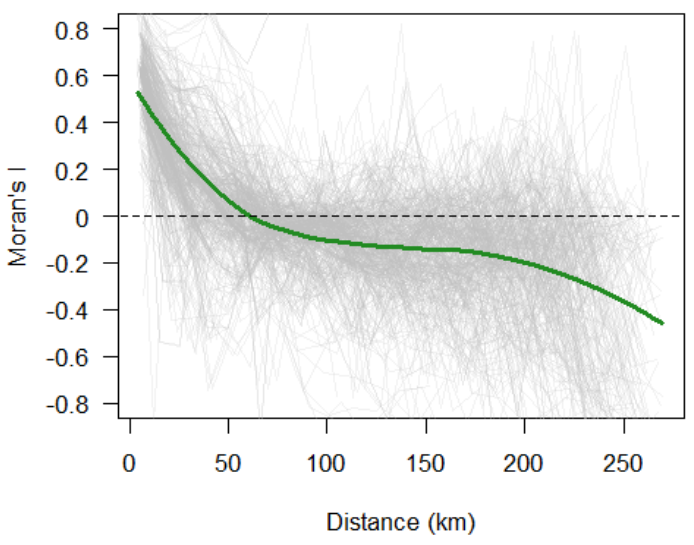

Observed alpha diversity

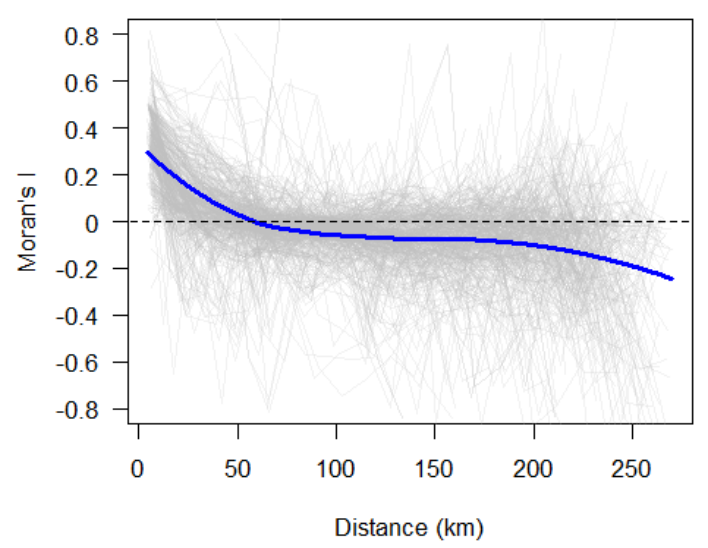

Residual alpha diversity

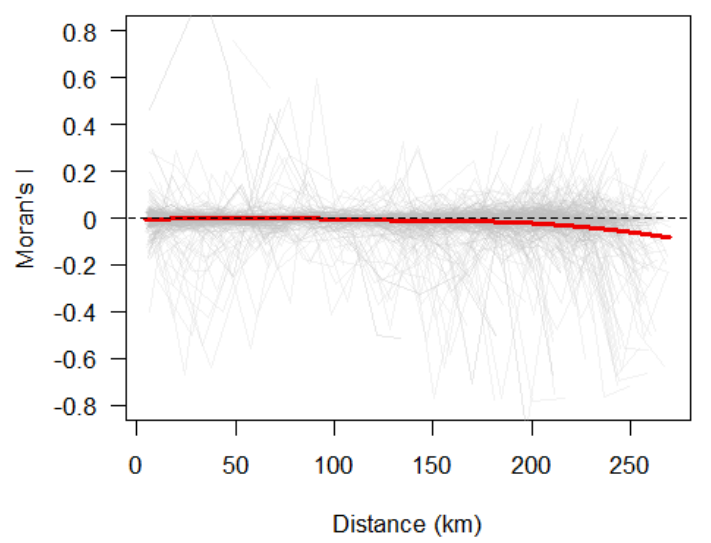

Figure S2.11 - Spatial correlograms of the residual, observed, and predicted alpha diversity for coniferous forests, calculated within 500 rectangular windows (a side length of $200 \mathrm{~km}$ ), randomly distributed across the sampled regions in Europe. 

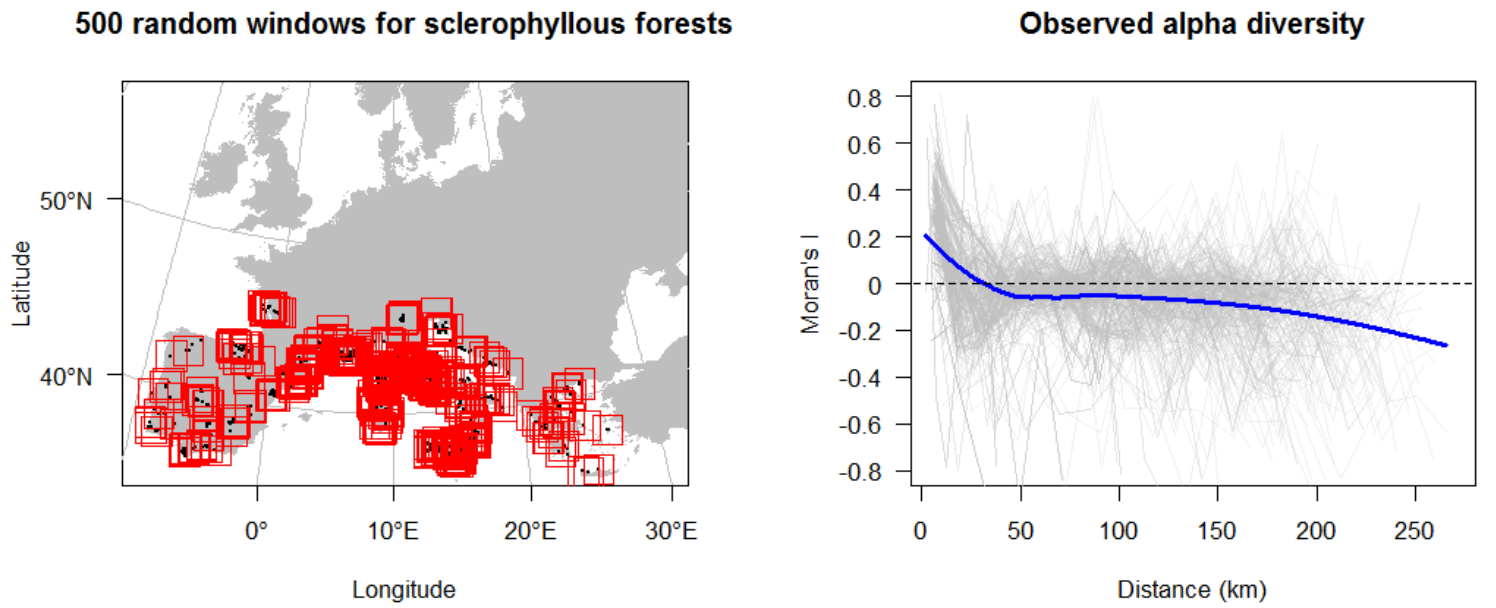

Residual alpha diversity
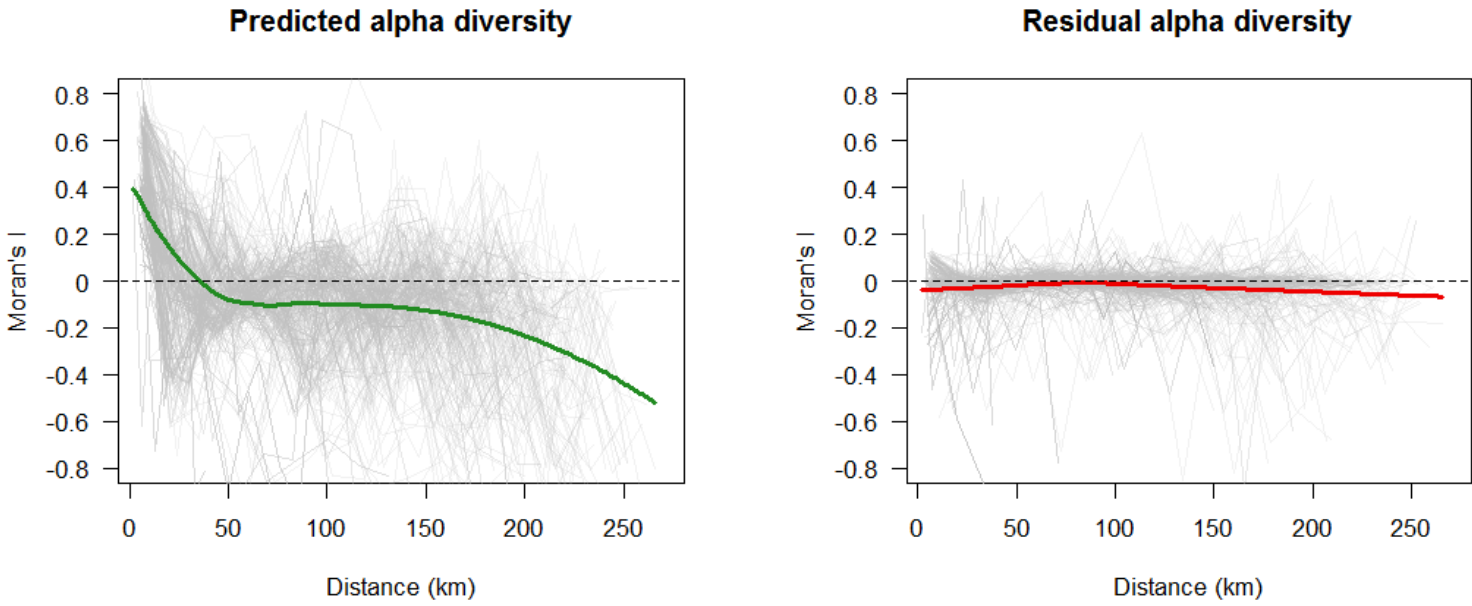

Figure S2.12 - Spatial correlograms of the residual, observed, and predicted alpha diversity for sclerophyllous forests, calculated within 500 rectangular windows (a side length of $200 \mathrm{~km}$ ), randomly distributed across the sampled regions in Europe. 
Supplement to the richness hotspots
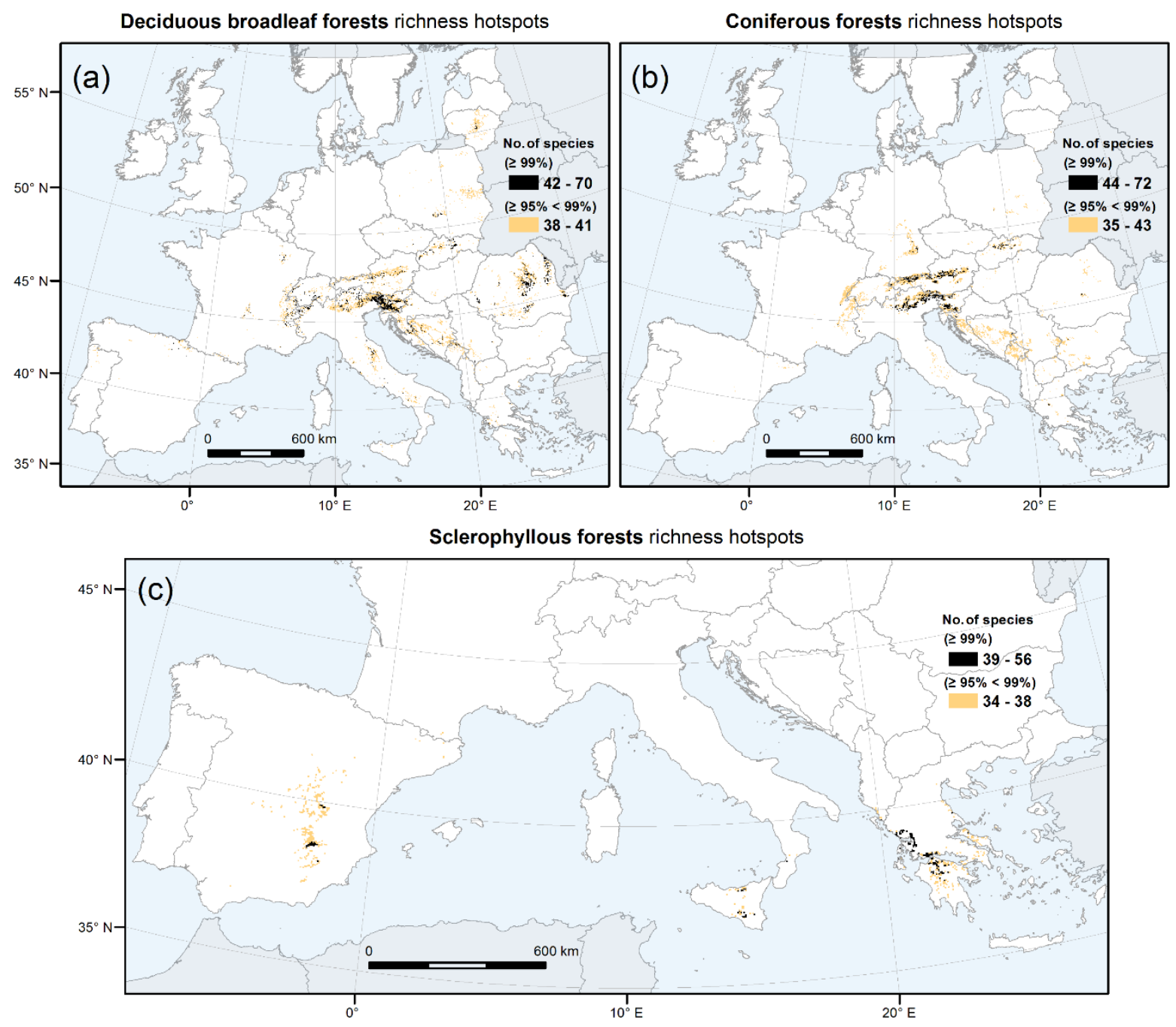

Figure S2.13 - Richness hotspots (light brown) and the top richness hotspots (black) of vascular plant alpha diversity in (a) deciduous broadleaf forests; (b) coniferous forests; and (c) sclerophyllous forests in Europe - grid cells with modelled richness values equal to or greater than the 95th and 99th percentile values, respectively. 


\section{Supplement to the relative importance of predictors}

\section{(a) All forests}
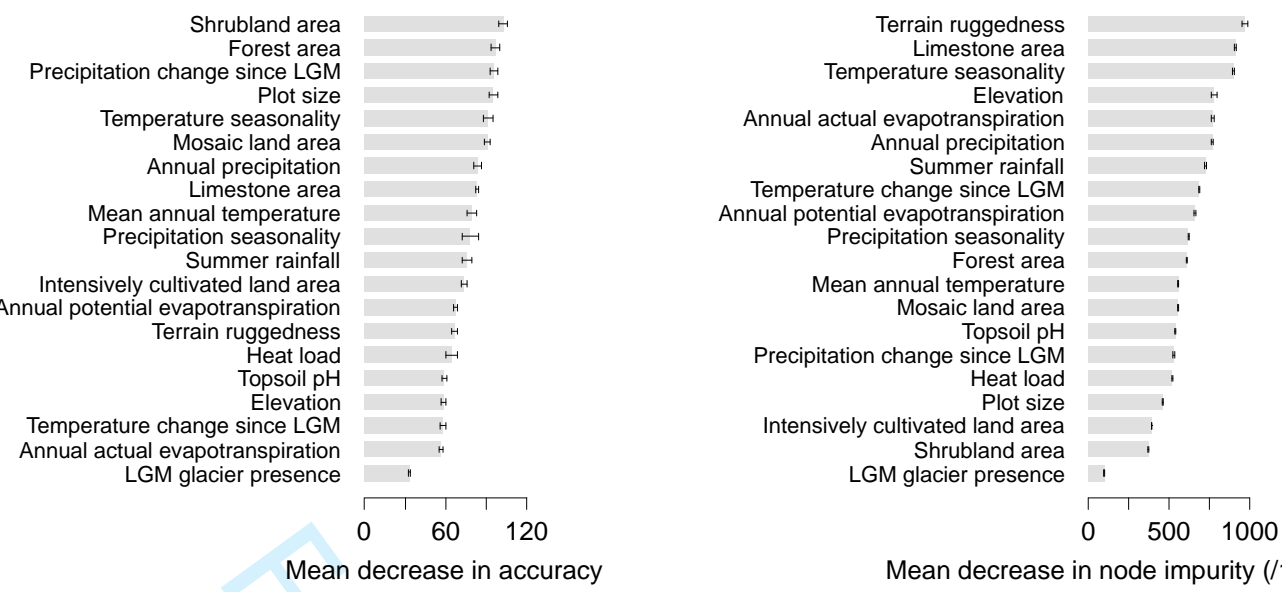

Mean decrease in accuracy

Mean decrease in node impurity (/1000)

(b) Deciduous broadleaf
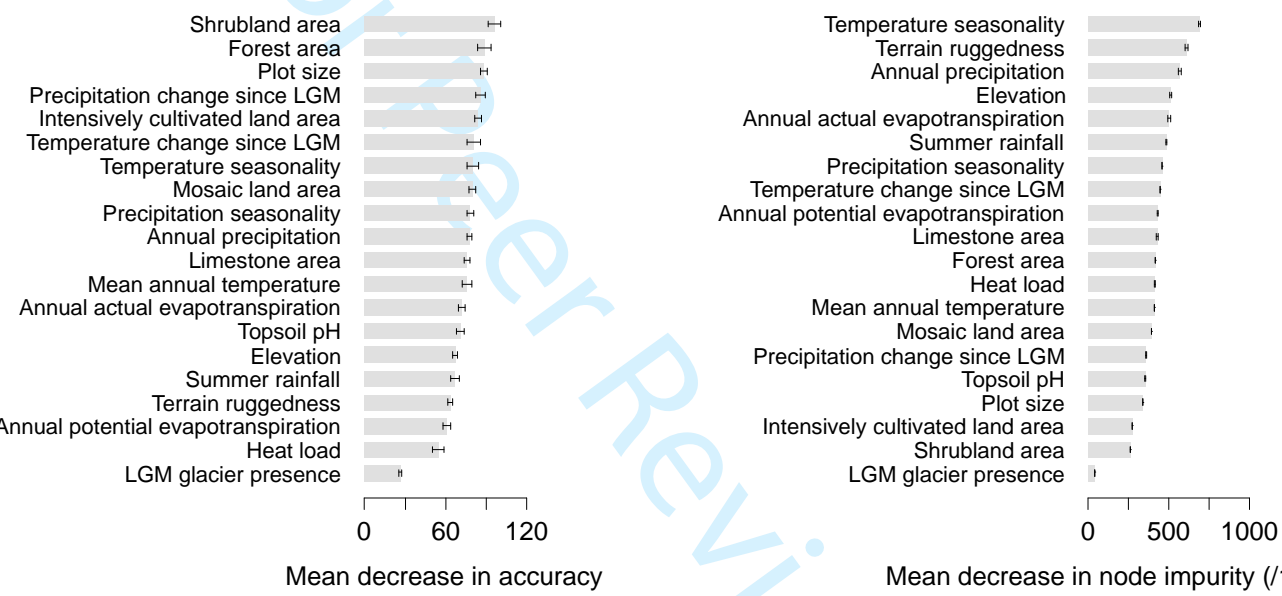

Mean decrease in node impurity (/1000)

(c) Coniferous

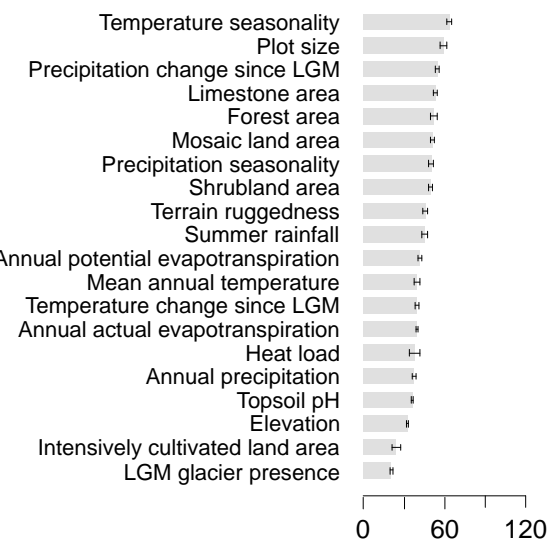

Mean decrease in accuracy

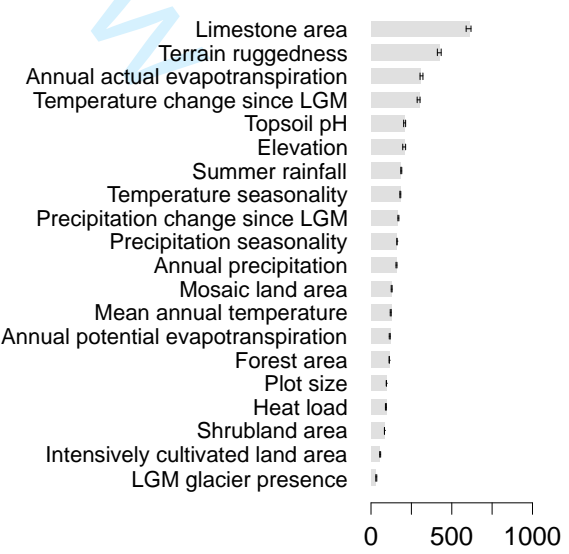

Mean decrease in node impurity $(/ 1000)$ 
Annual potential evapotranspiration Mosaic land area evapotranspiration Terrain ruggedness Shrubland area Forest area Annual precipitation Heat load Heat load
Plot size

Temperature seasonality Mean annual temperature Precipitation change since LGM Elevation
Intensively cultivated land area Topsoil pH
Tond area Temperature change since LGM Summer rainfall

(d) Sclerophyllous

Figures $S 2.15-S 2.18$

Figure S2.14 - Relative importance of predictor variables for explaining alpha-diversity pattern, measured by 'Mean decrease in accuracy' and 'Mean decrease in node impurity', for all forests and for each forest type separately. LGM - Last Glacial Maximum.

Effects of predictor variables (ranked on 4th to 20th place according to the integrated importance score) on alpha diversity in European forests depicted with partial dependence plots. The integrated importance scores are shown in parentheses. AET - actual evapotranspiration; LGM - Last Glacial Maximum; PET - potential evapotranspiration; VRM - vector ruggedness measure. 


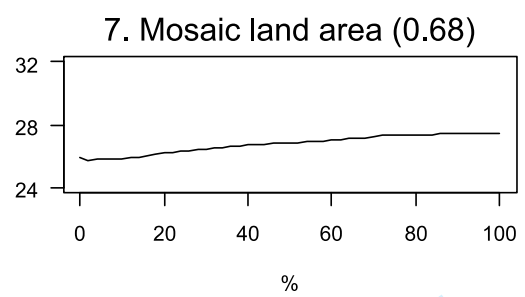

8. Summer rainfall $(0.67)$

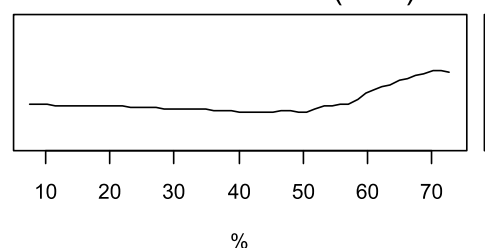

9. Shrubland area (0.66)

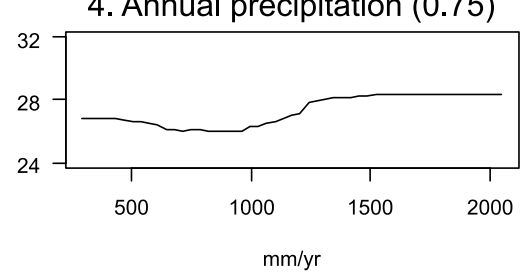

5. Terrain ruggedness $(0.74)$

6. Precipitation change since LGM (0.70)
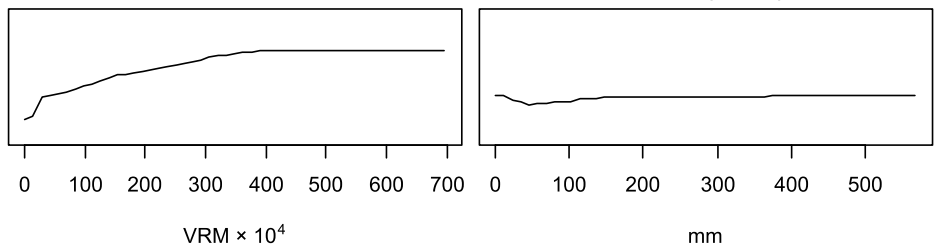

10. Plot size $(0.65)$

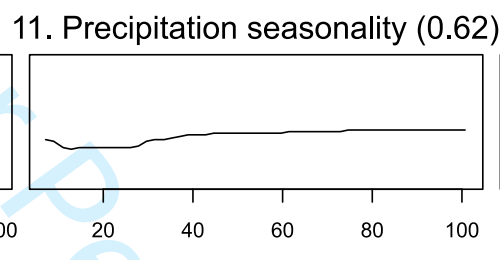

12. Mean annual

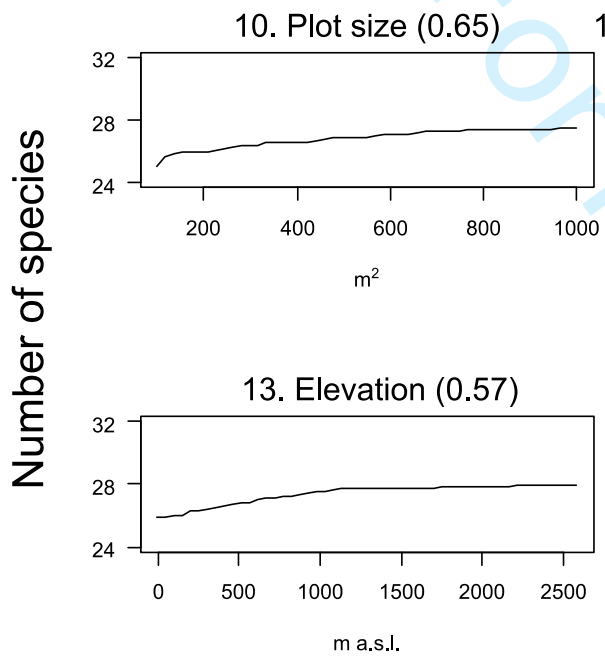

coeff. of var.

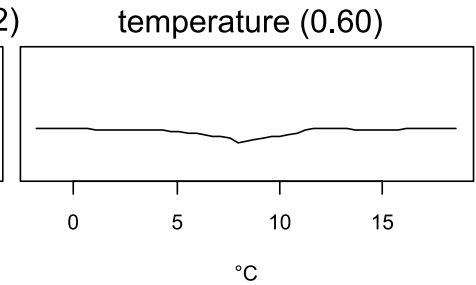

16. Temperature change since LGM (0.52)

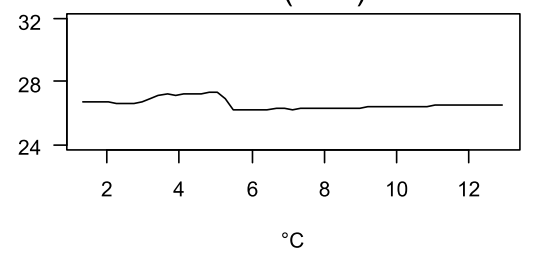

19. Topsoil pH (0.44)

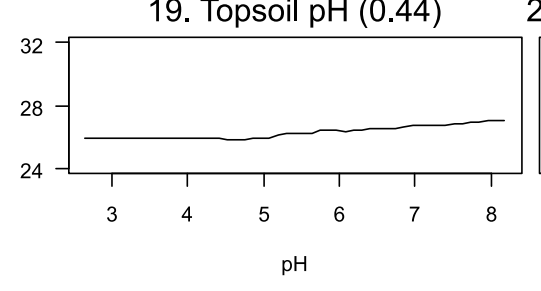

14. Annual PET (0.57)

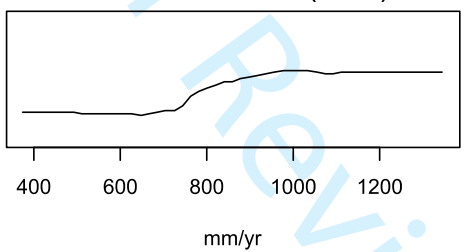

17. Heat load (0.47)

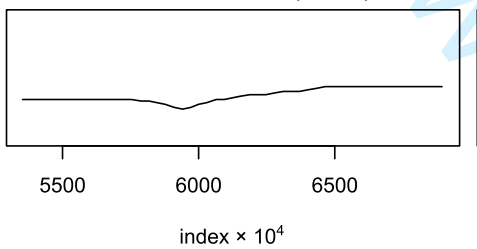

20. LGM glacier presence $(\sim 0.01)$

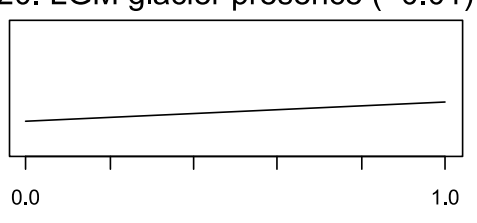

Figure S2.15 - Effects of predictor variables on alpha diversity modelled for all forests. 


\section{Deciduous broadleaf}
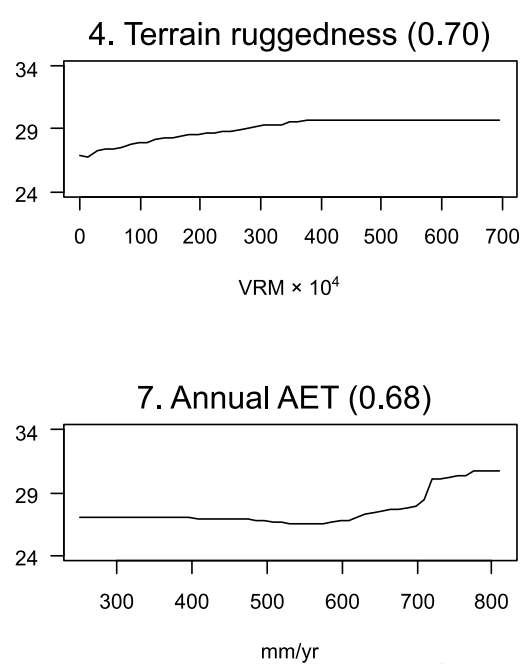

10. Shrubland area $(0.67)$

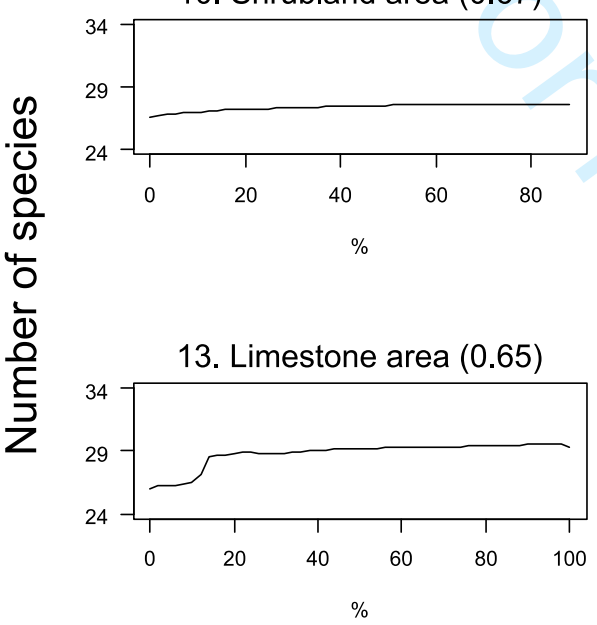

16. Intensively cultivated land area (0.59)

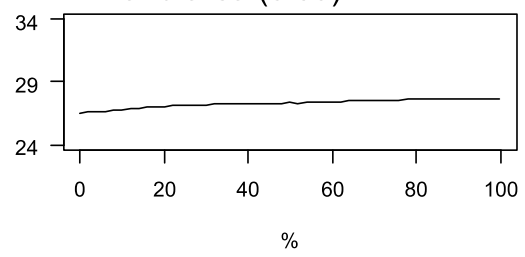

$\%$

19. Heat load (0.49)

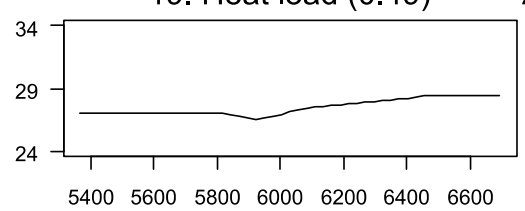

index $\times 10^{4}$
5. Temperature change since LGM $(0.70)$

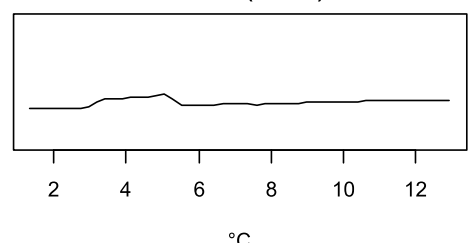

8. Plot size (0.67)

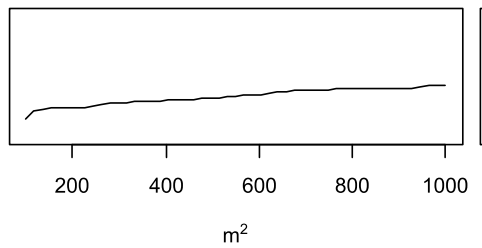

11. Elevation (0.65)

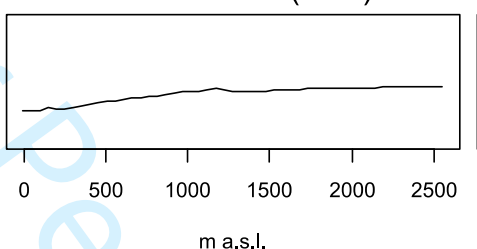

14. Mean annual temperature $(0.64)$

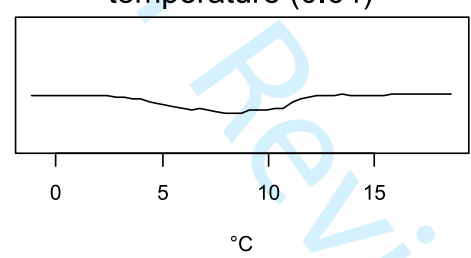

${ }^{\circ} \mathrm{C}$

17. Topsoil pH (0.56)

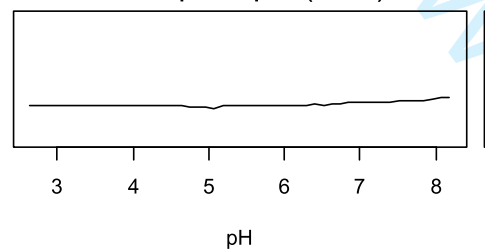

$\mathrm{pH}$ 20. LGM glacier presence ( 0.01)

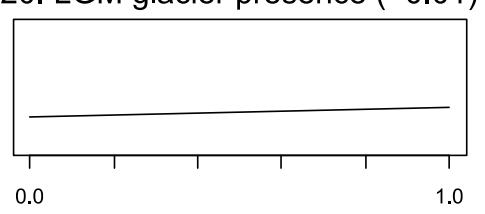

6. Precipitation seasonality $(0.69)$

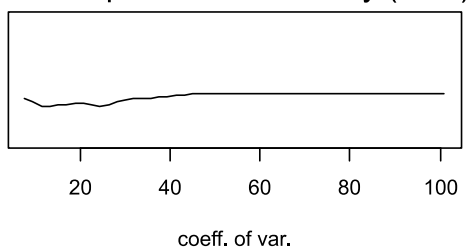

9. Precipitation change since LGM (0.67)

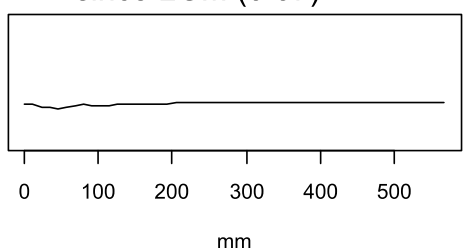

12. Mosaic land area (0.65)

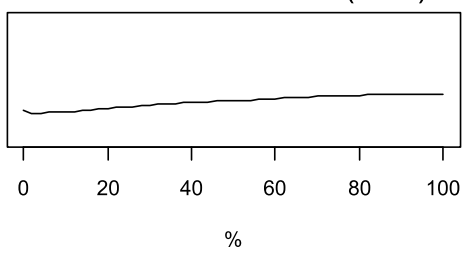

15. Summer rainfall $(0.63)$

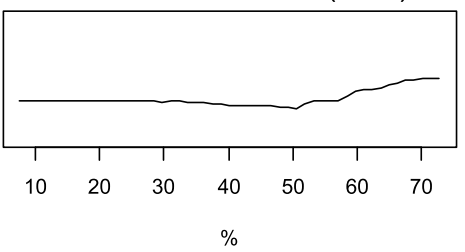

Figure S2.16 - Effects of predictor variables on alpha diversity modelled for deciduous broadleaf forests. 


\section{Coniferous}

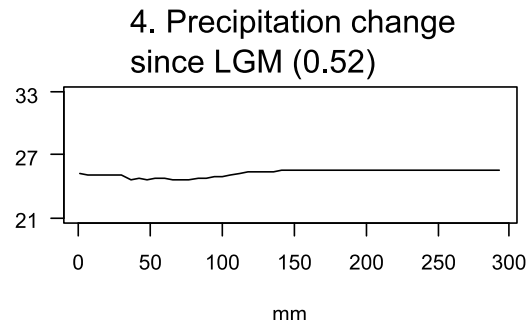

5. Plot size $(0.50)$

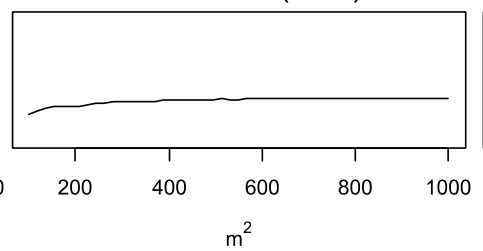

8. Temperature change

7. Precipitation seasonality $(0.45)$
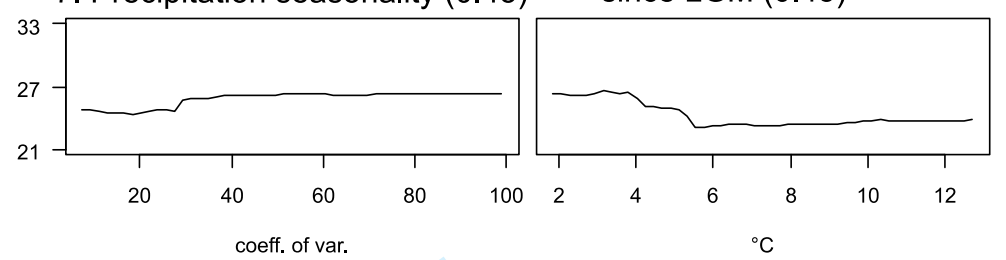

6. Annual AET (0.46)

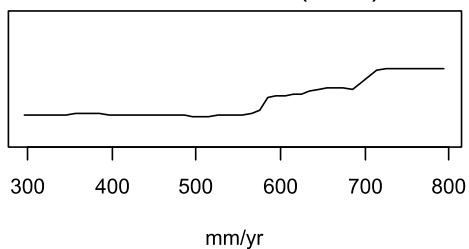

$\mathrm{m} / \mathrm{yr}$
9. Forest area $(0.44)$

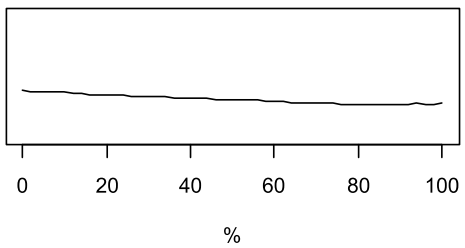

10. Mosaic land area $(0.45)$

11. Summer rainfall $(0.42)$
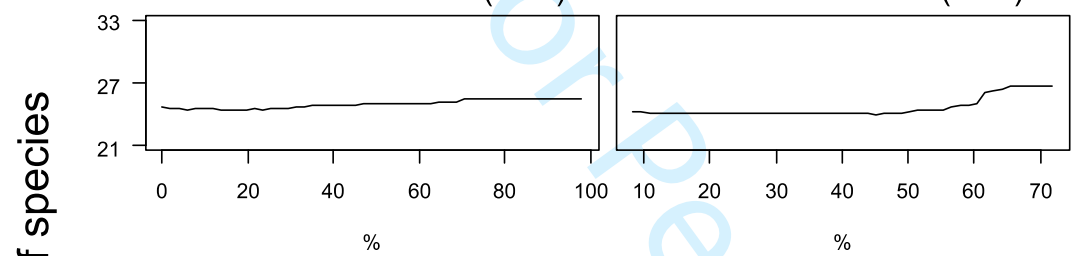

12. Shrubland area (0.38)

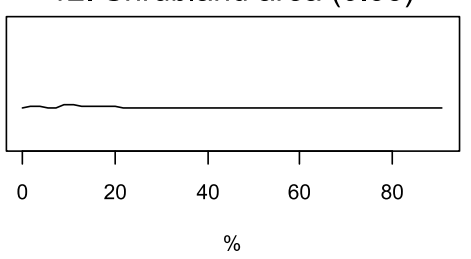

13. Topsoil $\mathrm{pH}(0.33)$

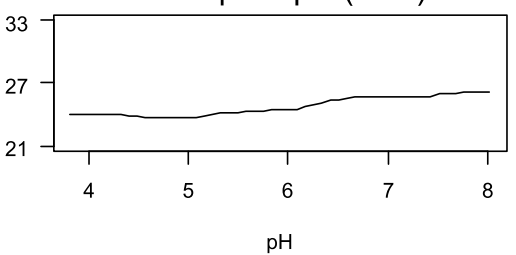

14. Annual PET (0.32)

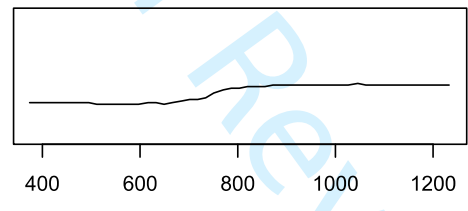

$\mathrm{mm} / \mathrm{yr}$

15. Annual precipitation (0.31)

16. Mean annual temperature $(0.30)$

17. Elevation (0.29)
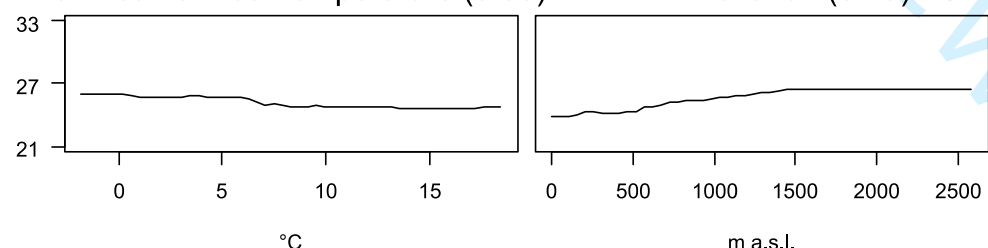

m a.s.I.

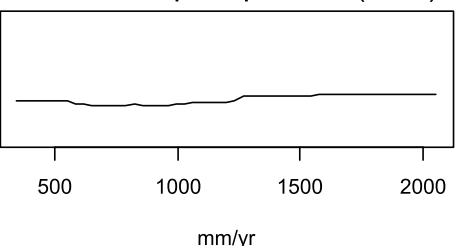

19. Intensively cultivated land area (0.06)

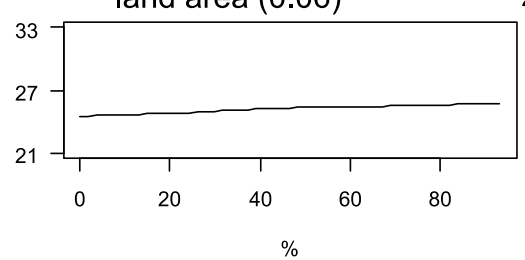

20. LGM glacier presence $(\sim 0.01)$

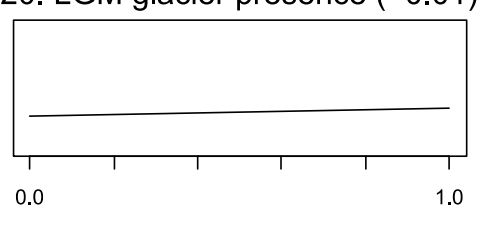

Figure S2.17 - Effects of predictor variables on alpha diversity modelled for coniferous forests. 


\section{Sclerophyllous}

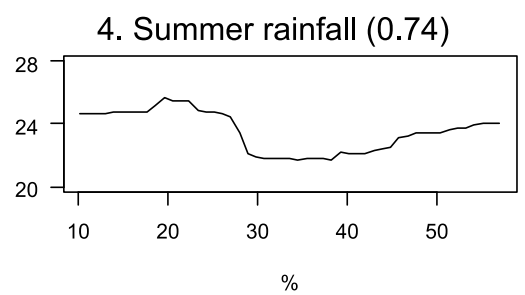

5. Mosaic land area (0.72)

6. Elevation (0.69)
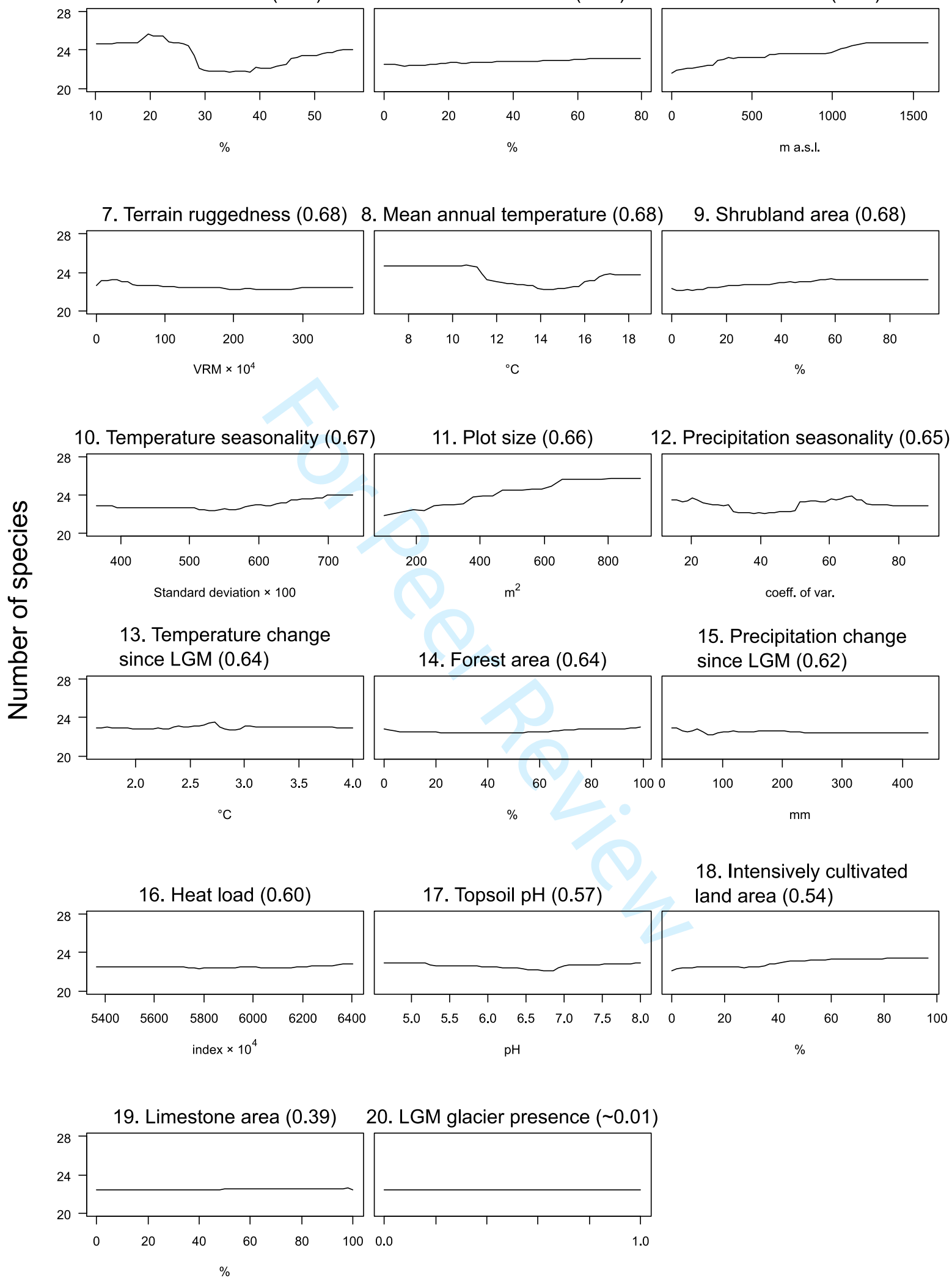

Figure S2.18 - Effects of predictor variables on alpha diversity modelled for sclerophyllous forests. 

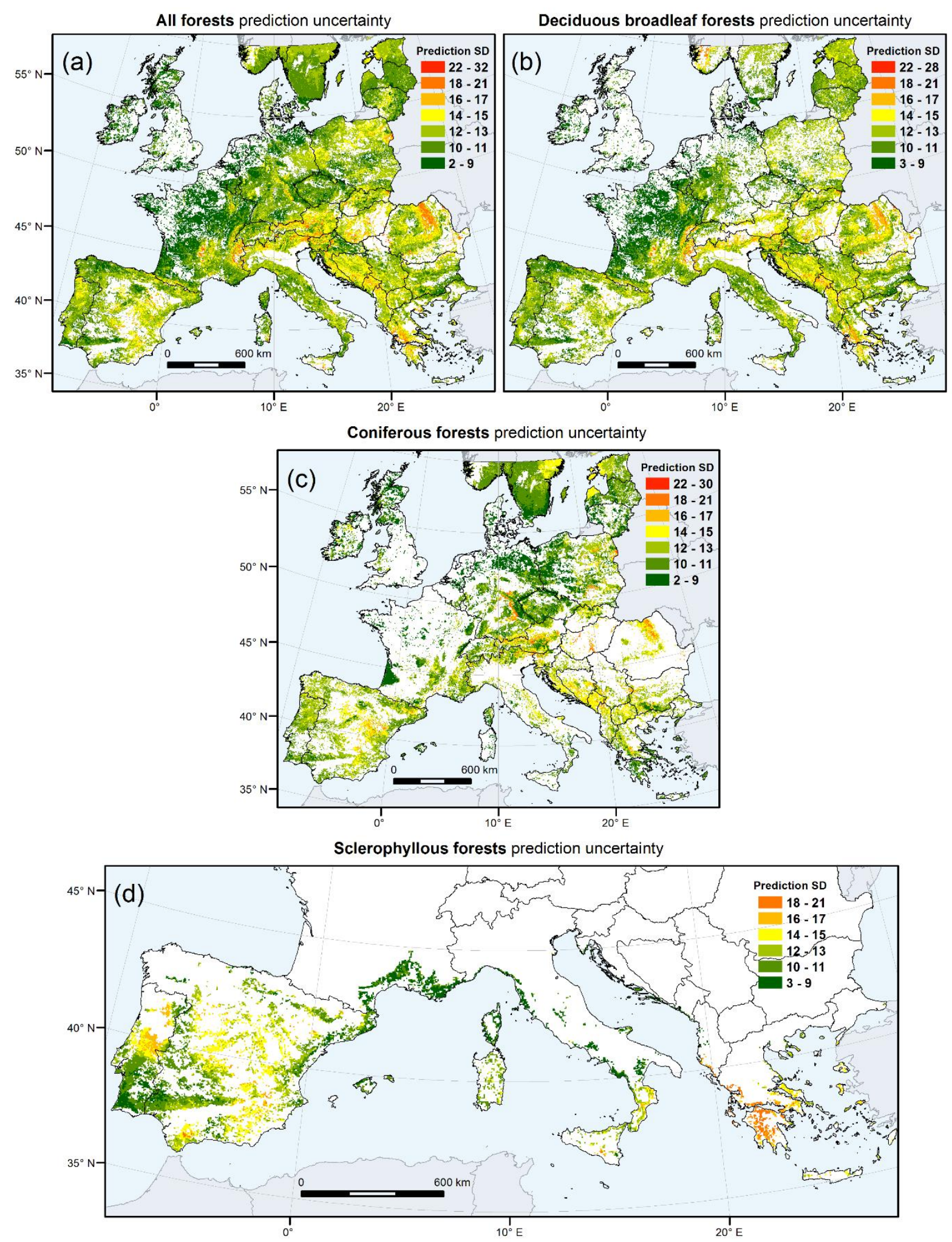

Figure S2.19 - Uncertainty of the predicted alpha diversity in (a) all forests, (b) deciduous broadleaf forests, (c) coniferous forests, and (d) sclerophyllous forests depicted as the standard deviation of predictions of individual regression trees $(\mathrm{n}=500)$ within respective Random Forest models. Grid cells with forest area $<10 \%$ (according to the CORINE Land Cover database; Bossard et al., 2000) are left white. See Figure 2 for details. 
Range of environmental conditions in plot data as covered by the grid used for prediction

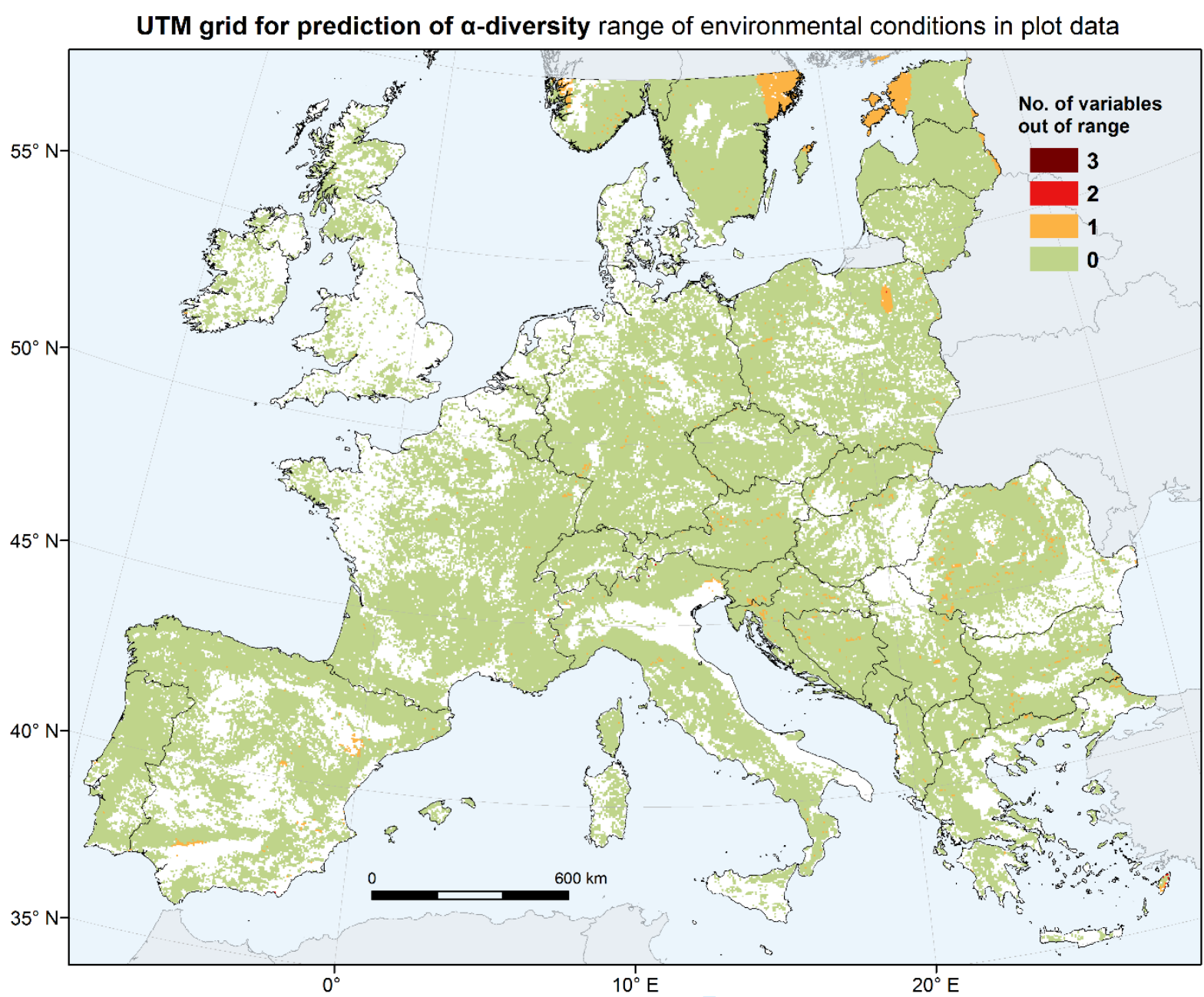

Figure S2.20 - UTM grid cells of $5 \times 5 \mathrm{~km}$ used for the prediction of alpha diversity. Colours indicate the number of explanatory variables of which values calculated in a particular cell are out of the range of conditions covered by the vegetation-plot data used to model alpha-diversity patterns. Grid cells with forest area $<10 \%$ (according to the CORINE Land Cover database; Bossard et al., 2000) are left white. 


\section{Tests of stability of the predicted alpha-diversity patterns}

Table S2.3 - Results of Random Forest models and spatial autocorrelation in model residuals for all forests based on four data subsets representing different resampling strategies: (a) non-resampled (original dataset), (b) resampled with the preference for richer plots, (c) resampled with randomly selected plots, and (d) undersampled. See also Resampling procedure to reduce local oversampling in Appendix S1.

\begin{tabular}{l|c|c|c|c}
\hline & $\begin{array}{c}\text { (a) } \\
\text { Non-resampled }\end{array}$ & $\begin{array}{c}\text { (b) } \\
\text { Resampled - } \\
\text { richer }\end{array}$ & $\begin{array}{c}\text { (c) } \\
\text { Resampled - } \\
\text { random }\end{array}$ & $\begin{array}{c}\text { (d) } \\
\text { Undersampled }\end{array}$ \\
\hline No. of cases (vegetation plots) & 73,134 & 54,086 & 53,187 & 48,756 \\
Explained variation [\%] & 56.3 & 48.5 & 47.4 & 51.3 \\
Mean of squared residuals & 80.2 & 89.5 & 89.6 & 84.8 \\
Moran's / at 1st lag distance ( \pm SD) & $-0.004 \pm 0.04$ & $-0.005 \pm 0.05$ & $-0.001 \pm 0.05$ & $-0.006 \pm 0.04$ \\
\hline
\end{tabular}
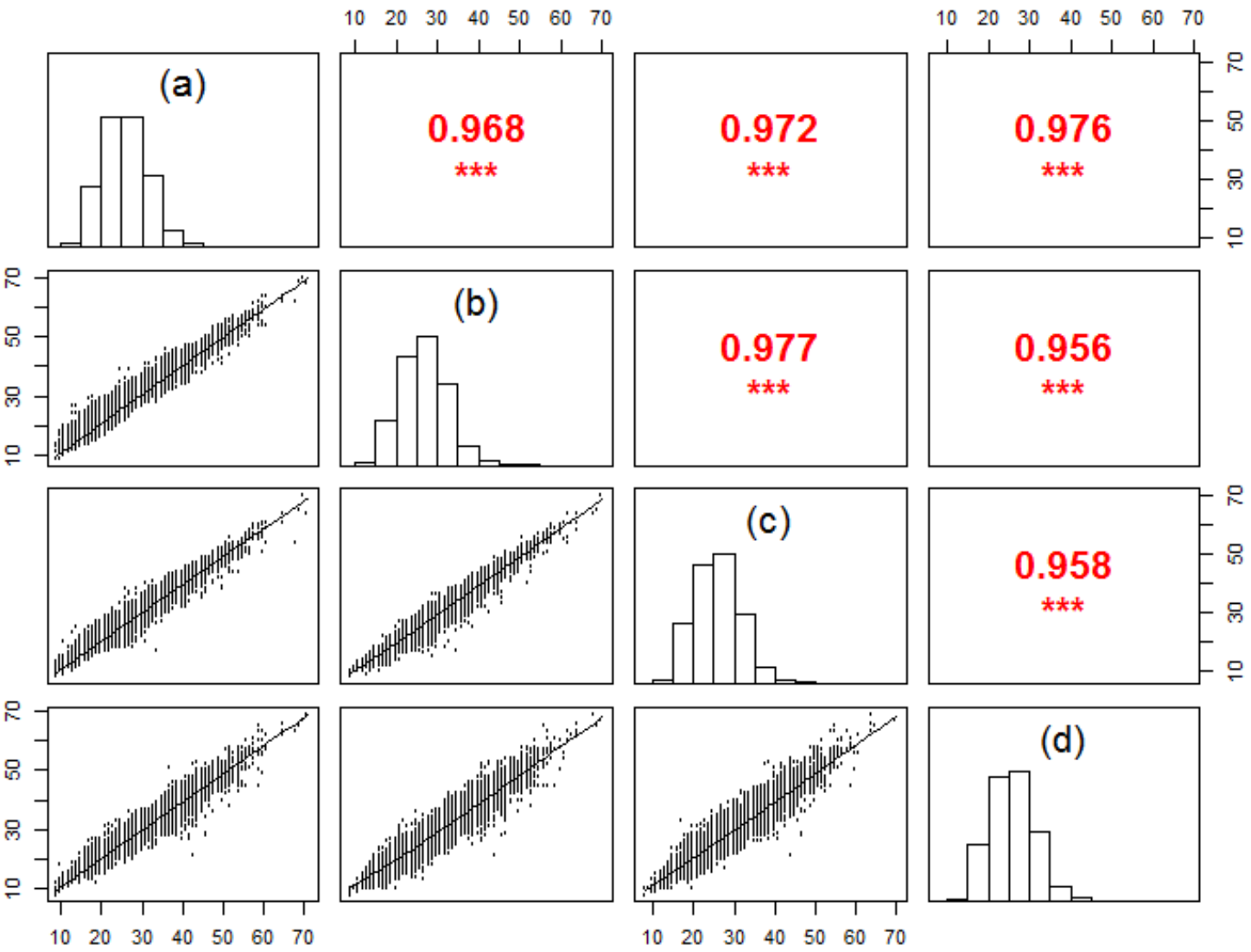

Figure S2.21 - Matrix of correlations between alpha-diversity patterns predicted by models based on four data subsets representing different resampling strategies: (a) non-resampled (original dataset), (b) resampled with the preference for richer plots, (c) resampled with randomly selected plots, and (d) undersampled. Upper triangle: Spearman's correlation coefficients and their significance (p-value '.$\geq 0.05$ and $<0.1$; ' ${ }^{*}$ ' $\geq 0.01$ and $<0.05$; '**' $\geq 0.001$ and $\left.<0.01 ;{ }^{\prime * * *}<0.001\right)$; lower triangle: scatter plots for pairs of variables. 
500 random windows for all forest types Resampled - richer

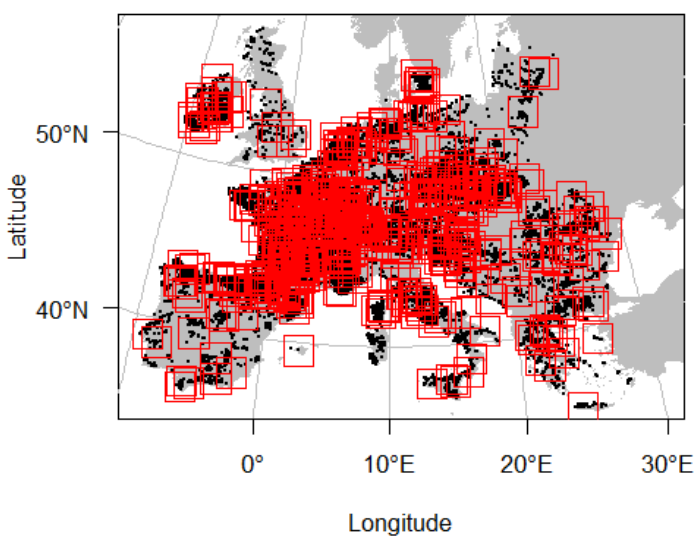

Predicted alpha diversity

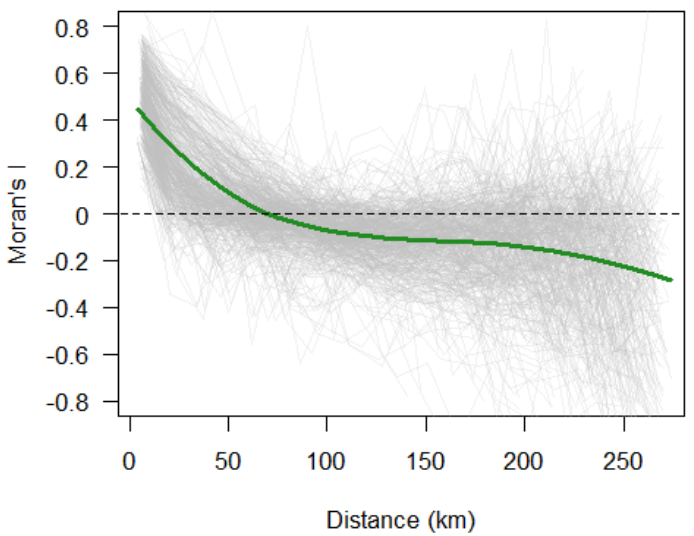

Observed alpha diversity

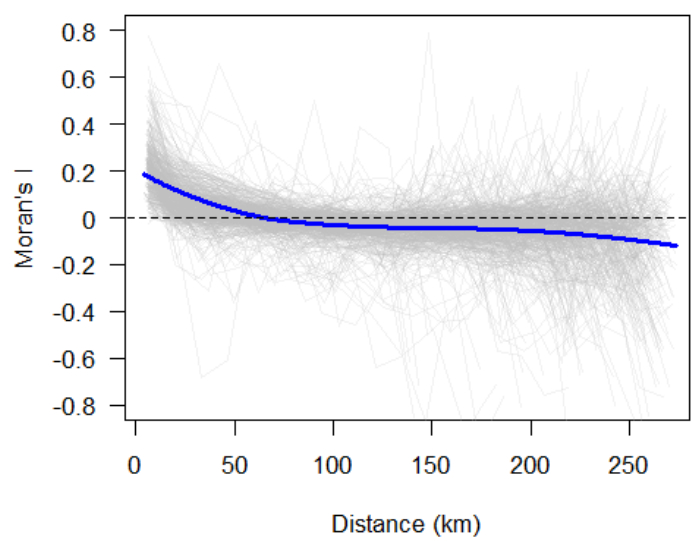

Residual alpha diversity

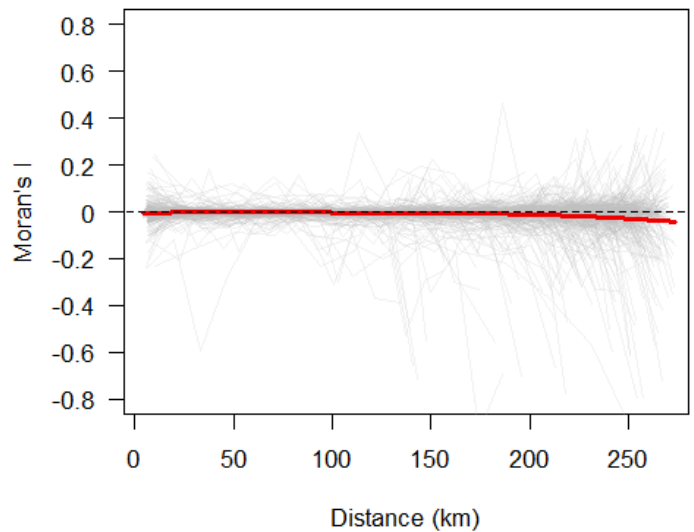

Figure S2.22 - Spatial correlograms of the residual, observed, and predicted alpha diversity for all forests based on the "Resampled - richer" data subset, calculated within 500 rectangular windows (a side length of $200 \mathrm{~km}$ ), randomly distributed across the sampled regions in Europe.

For spatial correlograms for the "Non-resampled" dataset, see Figure S2.9. 
500 random windows for all forest types Resampled - random
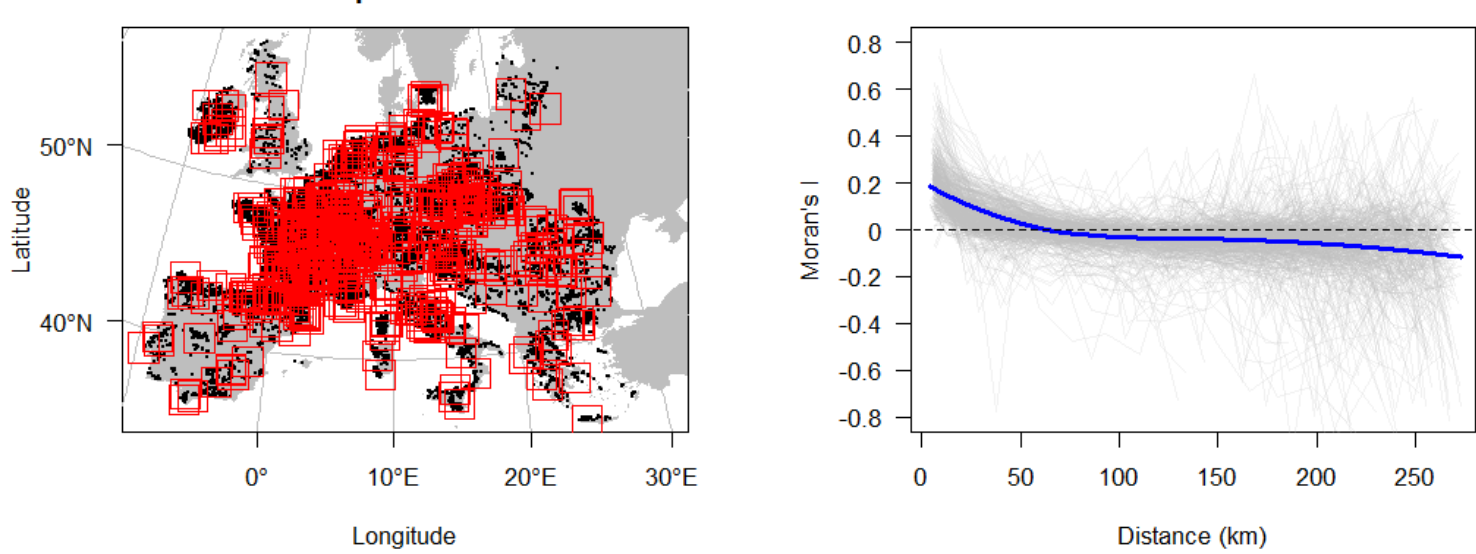

Predicted alpha diversity

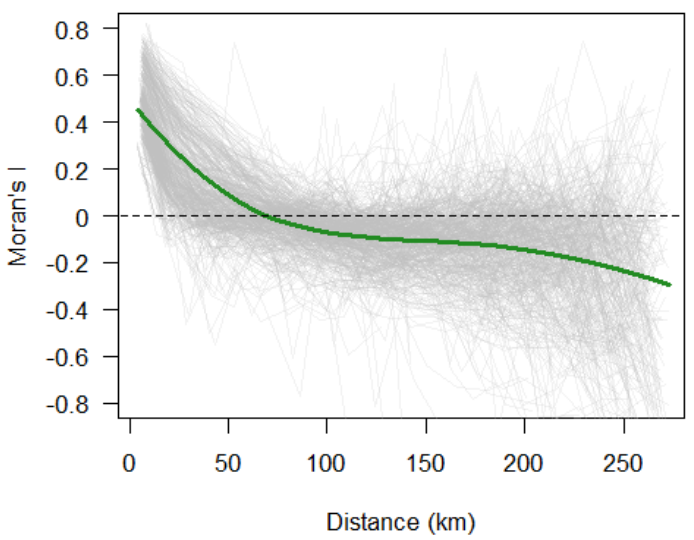

Residual alpha diversity

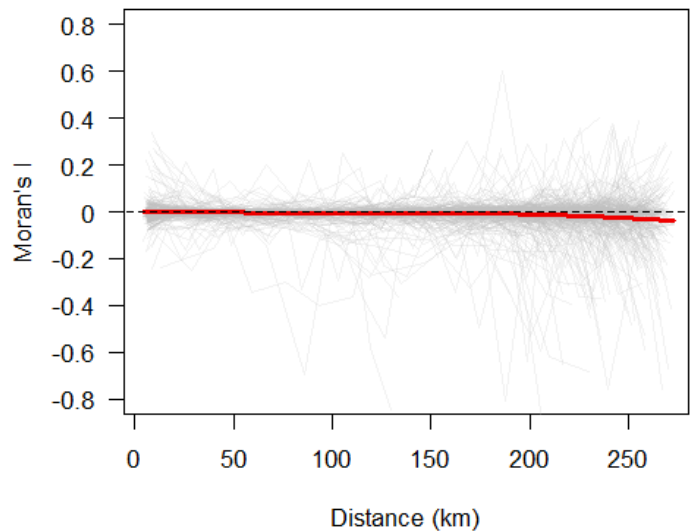

Figure S2.23 - Spatial correlograms of the residual, observed, and predicted alpha diversity for all forests based on the "Resampled - random" data subset, calculated within 500 rectangular windows (a side length of $200 \mathrm{~km}$ ), randomly distributed across the sampled regions in Europe. 

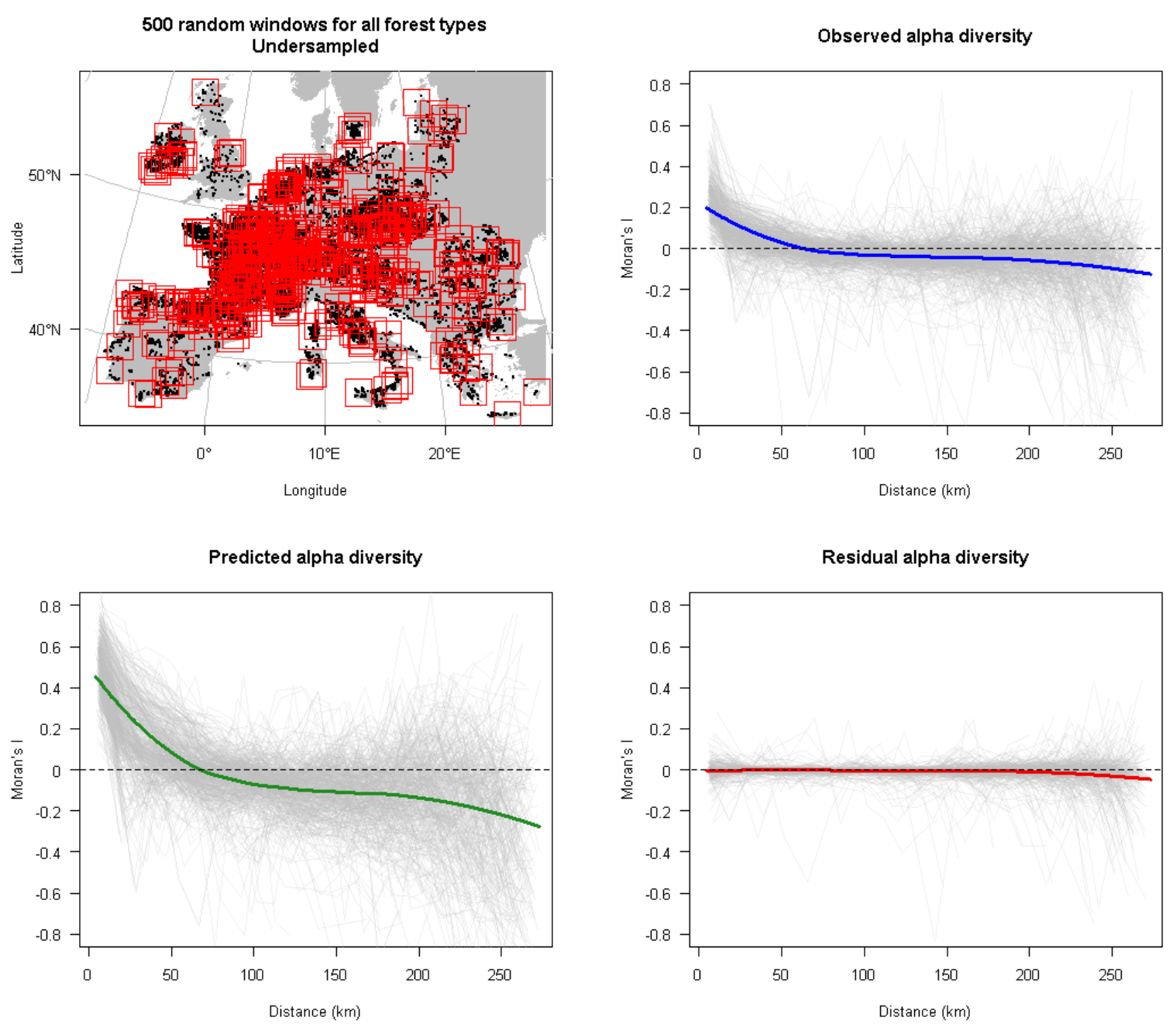

Figure S2.24 - Spatial correlograms of the residual, observed, and predicted alpha diversity for all forests based on the "Undersampled" data subset, calculated within 500 rectangular windows (a side length of $200 \mathrm{~km}$ ), randomly distributed across the sampled regions in Europe. 


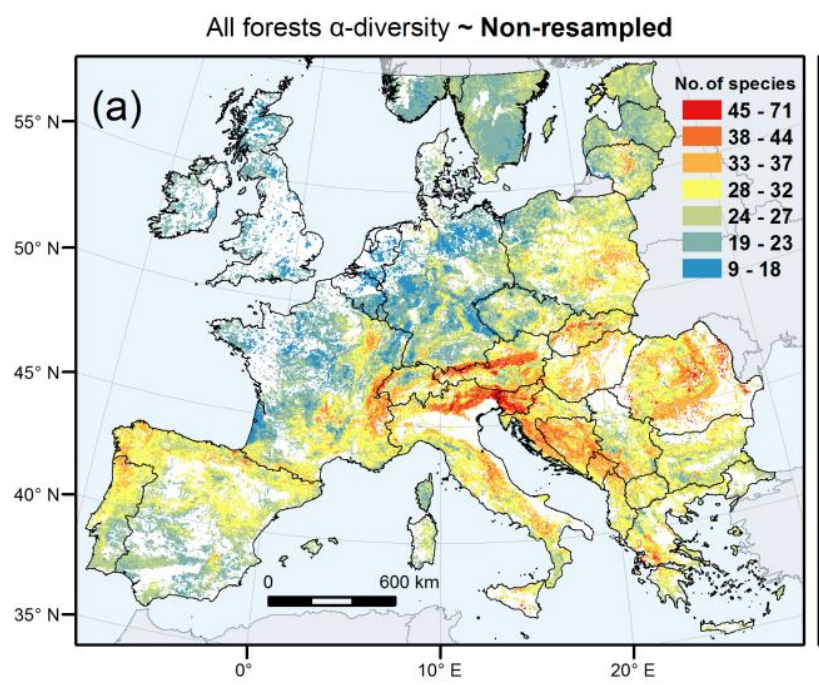

All forests $\alpha$-diversity $\sim$ Resampled - richer

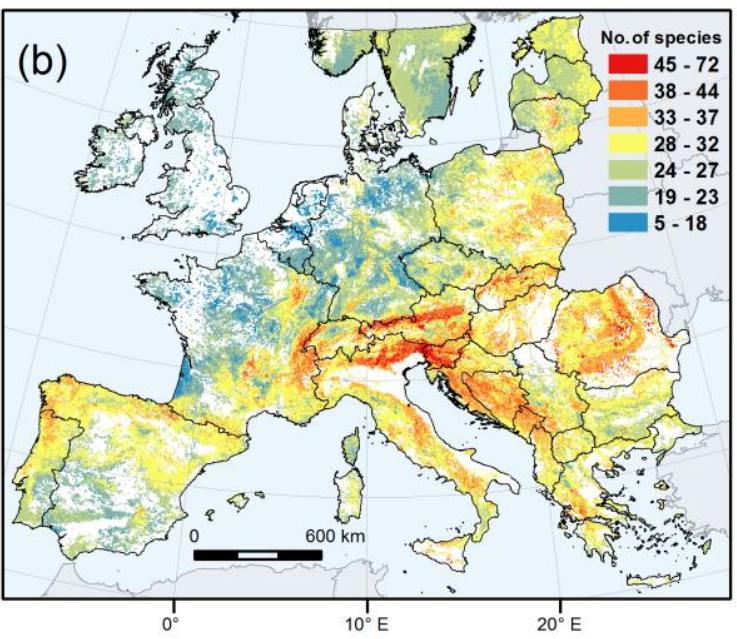

All forests $\alpha$-diversity $\sim$ Resampled - random
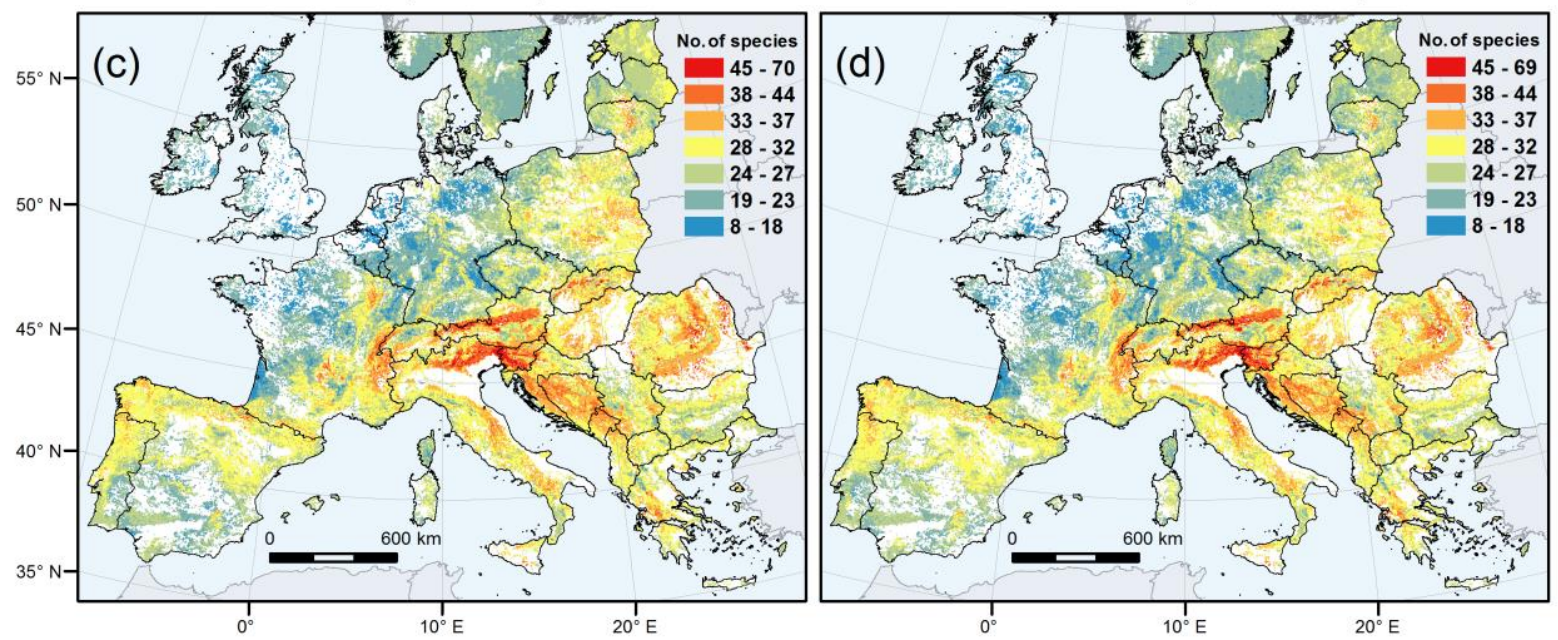

Figure S2.25 - Vascular plant alpha diversity of all forests in Europe - comparison of the predictive maps based on four data subsets representing different resampling strategies: (a) non-resampled (original dataset), (b) resampled with the preference for richer plots, (c) resampled with randomly selected plots, and (d) undersampled. 


\section{Supplementary references}

Bossard, M., Feranec, J., \& Ot'ahel', J. (2000). CORINE Land Cover technical guide - addendum 2000. Copenhagen, DK: European Environment Agency.

CEC (2004). The European Soil Database distribution version 2.0. European Commission and the European Soil Bureau Network (CD-ROM), EUR 19945 EN.

Chytrý, M., Hennekens, S. M., Jiménez-Alfaro, B., Knollová, I., Dengler, J., Jansen, F., ... Yamalov, S. (2016). European Vegetation Archive (EVA): an integrated database of European vegetation plots. Applied Vegetation Science, 19, 173-180.

Ehlers, J., Gibbard, P. L., \& Hughes, P. D. (Eds). (2011). Quaternary glaciations - extent and chronology: a closer look. Oxford, UK: Elsevier.

Hijmans, R. J., Cameron, S. E., Parra, J. L., Jones, P. G., \& Jarvis, A. (2005). Very high resolution interpolated climate surfaces for global land areas. International Journal of Climatology, 25, 19651978.

Jarvis, A., Reuter, H. I., Nelson, A., \& Guevara, E. (2008). Hole-filled SRTM for the globe Version 4. Available from the CGIAR-CSI SRTM 90m Database: http://srtm.csi.cgiar.org/.

Koleff, P., Gaston, K. J., \& Lennon, J. J. (2003). Measuring beta diversity for presence-absence data. Journal of Animal Ecology, 72, 367-382.

McCune, B. \& Keon, D. (2002). Equations for potential annual direct incident radiation and heat load. Journal of Vegetation Science, 13, 603-606.

Panagos, P., Van Liedekerke, M., Jones, A., \& Montanarella, L. (2012). European Soil Data Centre: Response to European policy support and public data requirements. Land Use Policy, 29, 329-338.

Sappington, J. M., Longshore, K. M., \& Thompson, D. B. (2007). Quantifying landscape ruggedness for animal habitat analysis: a case study using bighorn sheep in the Mojave Desert. Journal of Wildlife Management, 71, 1419-1426.

Schaminée, J. H. J., Chytrý, M., Hennekens, S. M., Janssen, J. A. M., Jiménez-Alfaro, B., Knollová, I., ... Data-providers (2014). Vegetation analysis and distribution maps for EUNIS habitats. Report EEA/NSV/14/006. Copenhagen, DK: European Environment Agency.

Trabucco, A. \& Zomer, R.J. (2010). Global Soil Water Balance Geospatial Database. CGIAR Consortium for Spatial Information.

Wieder, W. R., Boehnert, J., Bonan, G. B., \& Langseth, M. (2014). Regridded Harmonized World Soil Database v1.2. Data set. Available on-line [http://daac.ornl.gov] from Oak Ridge National Laboratory Distributed Active Archive Center. Oak Ridge, TN, USA.

Zomer, R. J., Trabucco, A., Bossio, D. A., van Straaten, O., \& Verchot, L.V. (2008). Climate change mitigation: a spatial analysis of global land suitability for clean development mechanism afforestation and reforestation. Agriculture, Ecosystems \& Environment, 126, 67-80. 


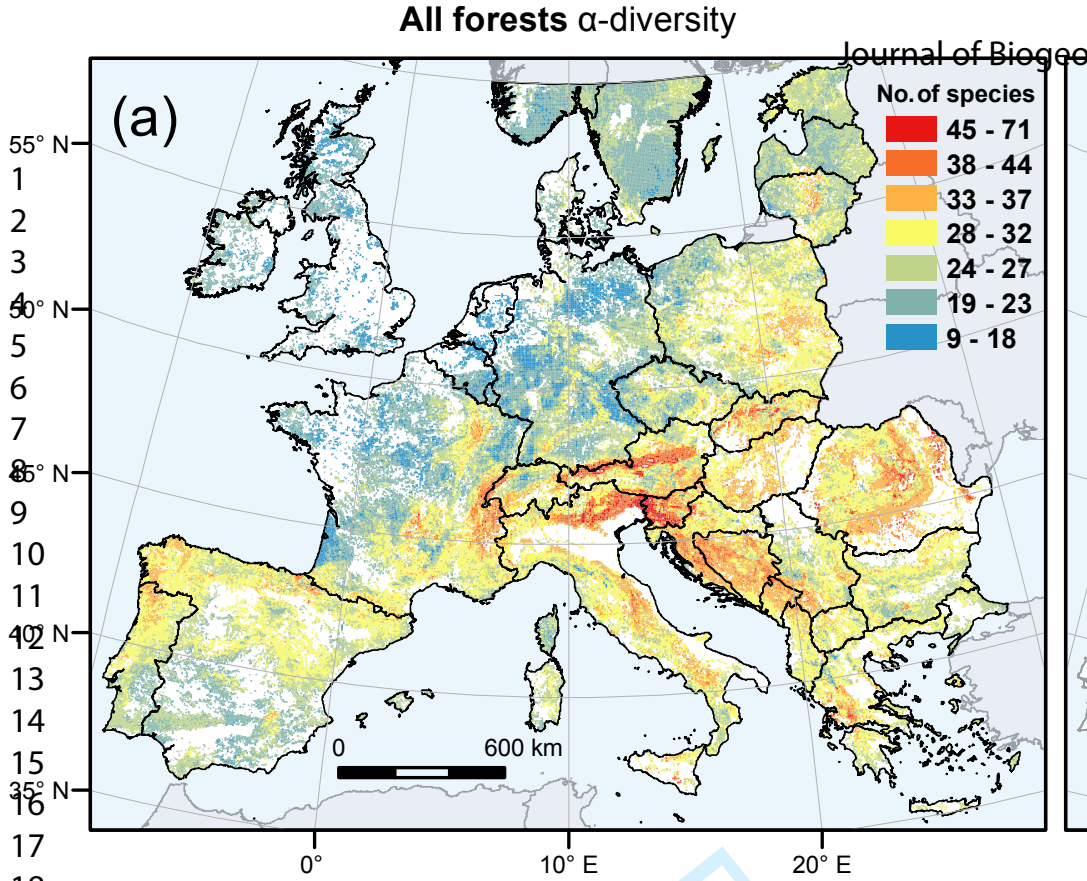

All forests richness hotspots

18

19

Deciduous broadleaf forests $\alpha$-diversity


Coniferous forests $\alpha$-diversity

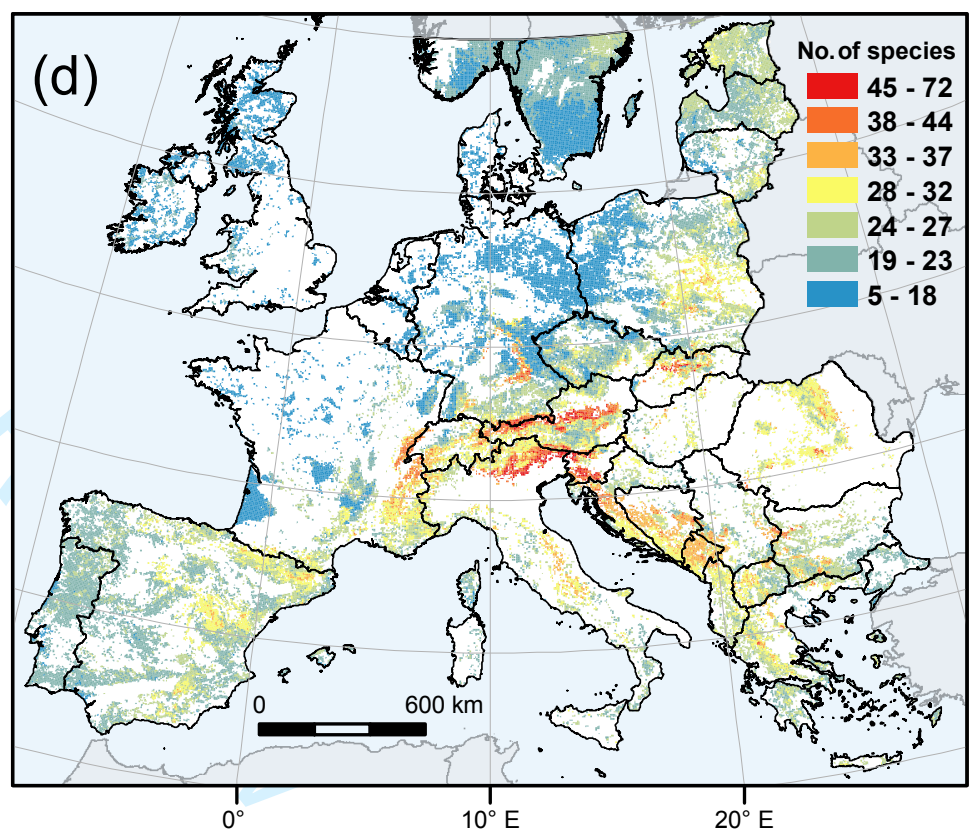

Sclerophyllous forests $\alpha$-diversity

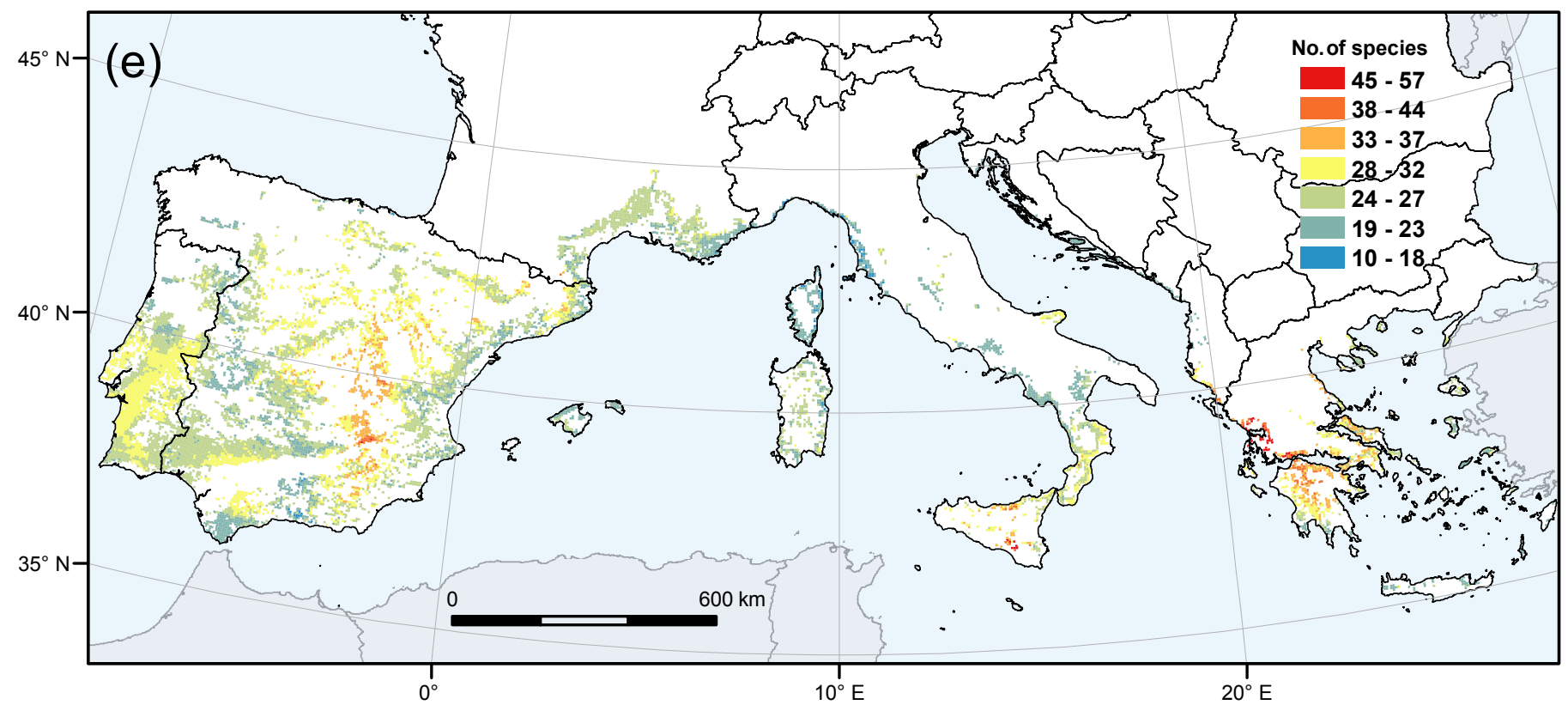


Temperature seasonality

Limestone area

Forest area

Annual precipitation

Terrain ruggedness

Precipitation change since LGM

Mosaic land area

Summer rainfall

Shrubland area

Plot size

Precipitation seasonality

Mean annual temperature

Elevation

nnual potential evapotranspiration

Annual actual evapotranspiration

Temperature change since LGM

Heat load

Intensively cultivated land area

Topsoil pH

LGM glacier presence

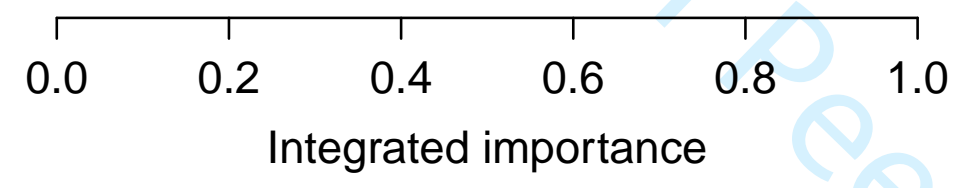

(c) Coniferous

Limestone area

Terrain ruggedness

Temperature seasonality

Precipitation change since LGM

Plot size

Annual actual evapotranspiration

Precipitation seasonality Temperature change since LGM

Forest area

Mosaic land area

Summer rainfall

Shrubland area

Topsoil $\mathrm{pH}$

nual potential evapotranspiration

Annual precipitation

Mean annual temperature

Elevation

Heat load

Intensively cultivated land area

LGM glacier presence

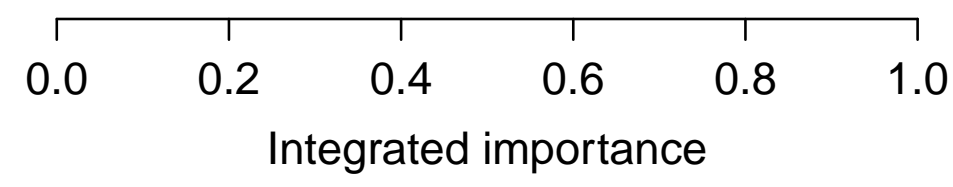

Temperature seasonality

Annual precipitation

Forest area

Terrain ruggedness

Temperature change since LGM

Precipitation seasonality

Annual actual evapotranspiration

Plot size

Precipitation change since LGM

Shrubland area

Elevation

Mosaic land area

Limestone area

Mean annual temperature

Summer rainfall

Intensively cultivated land area

Topsoil pH

Annual potential evapotranspiration Heat load

LGM glacier presence

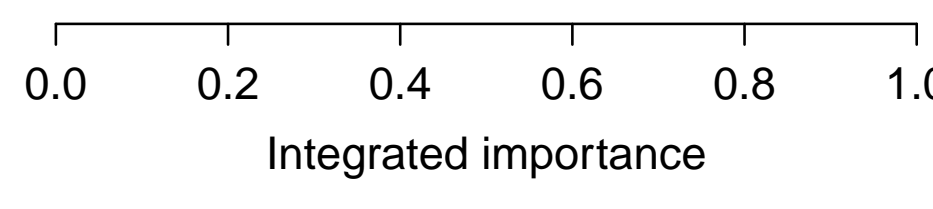

(d) Sclerophyllous

Annual actual evapotranspiration

Annual precipitation

Annual potential evapotranspiration

Summer rainfall

Mosaic land area

Elevation

Terrain ruggedness

Mean annual temperature

Shrubland area

Temperature seasonality

Plot size

Precipitation seasonality

Temperature change since LGM

Forest area

Precipitation change since LGM

Heat load

Topsoil pH

Intensively cultivated land area

Limestone area

LGM glacier presence
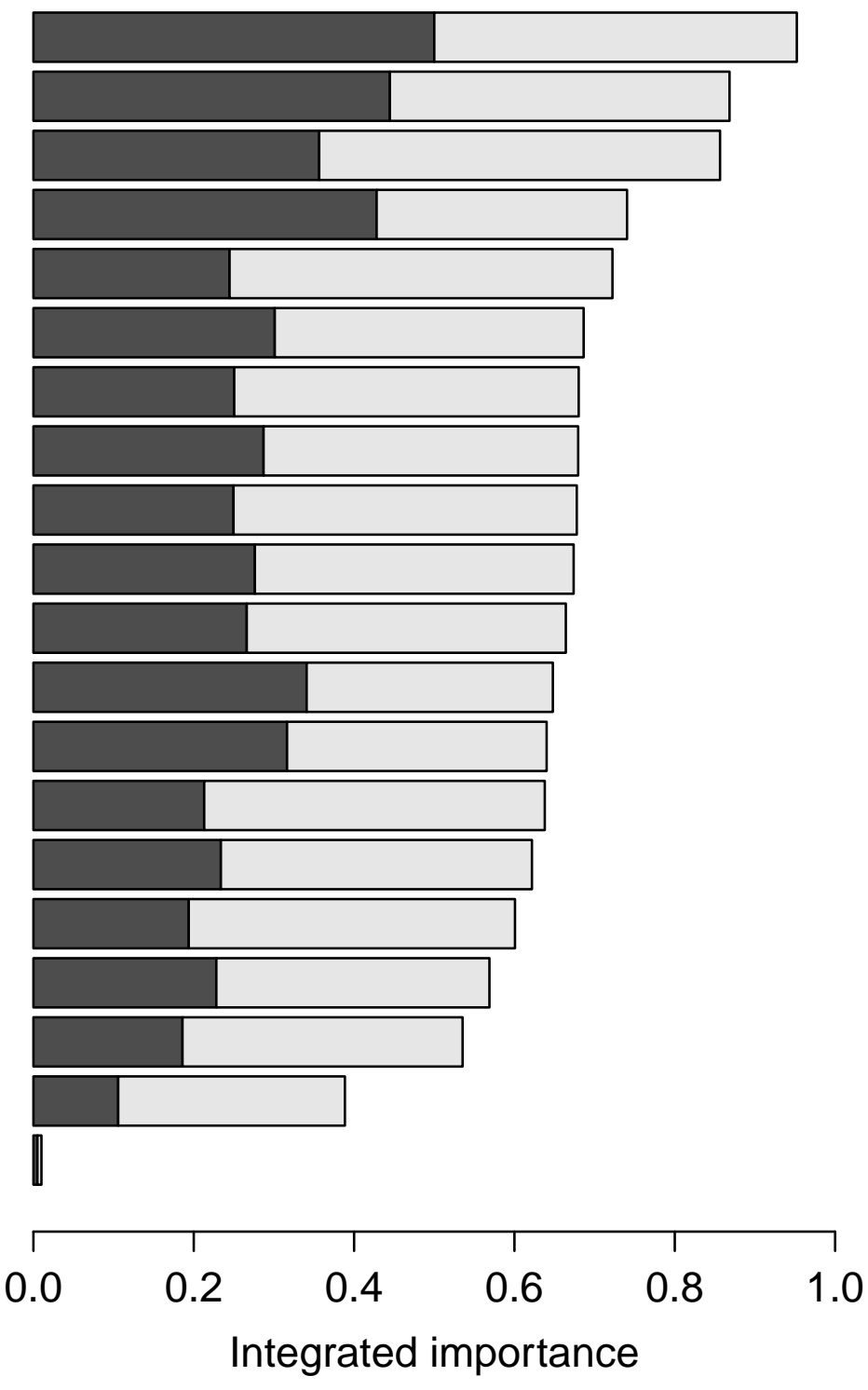


\section{(a) All forests}

$\begin{array}{ll}\text { 1. Temperature seasonality }(0.88) & \text { 2. Limestone area }(0.83)\end{array}$
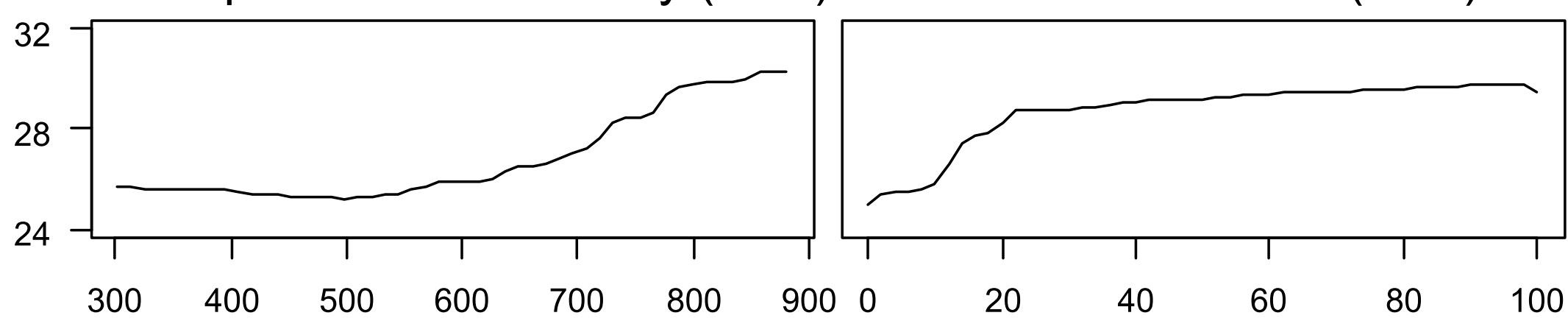

Standard deviation $\times 100$

$\%$

3. Forest area (0.75)

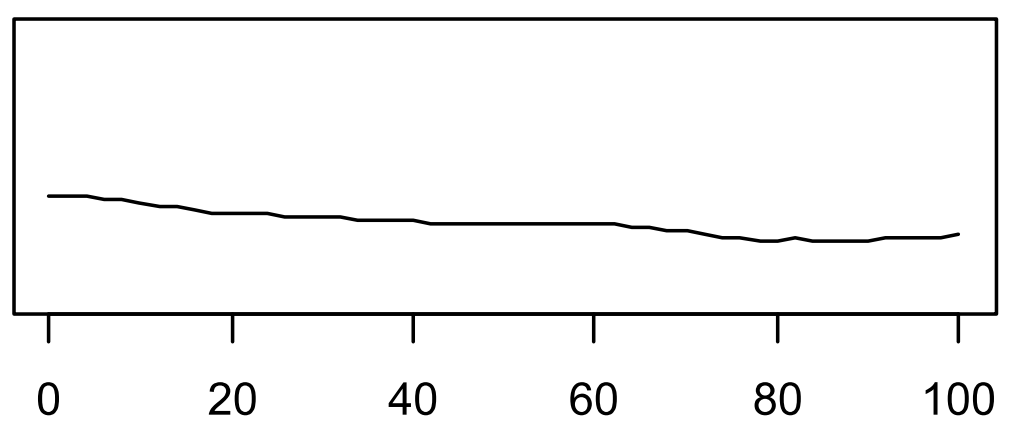

$\%$

\section{(b) Deciduous broadleaf}

$\begin{array}{ll}\text { 1. Temperature seasonality }(0.88) & 2 \text {. Annual precipitation }(0.77)\end{array}$

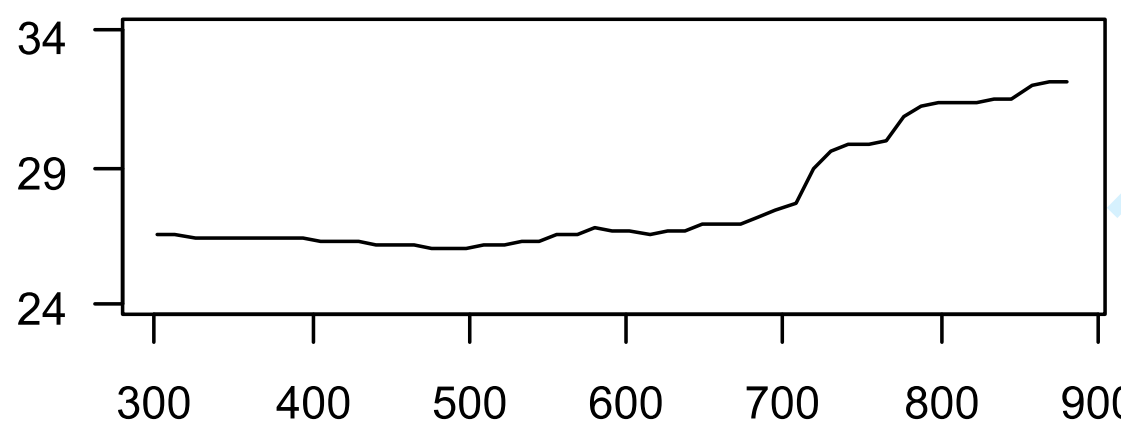

Standard deviation $\times 100$

1. Limestone area $(0.88)$

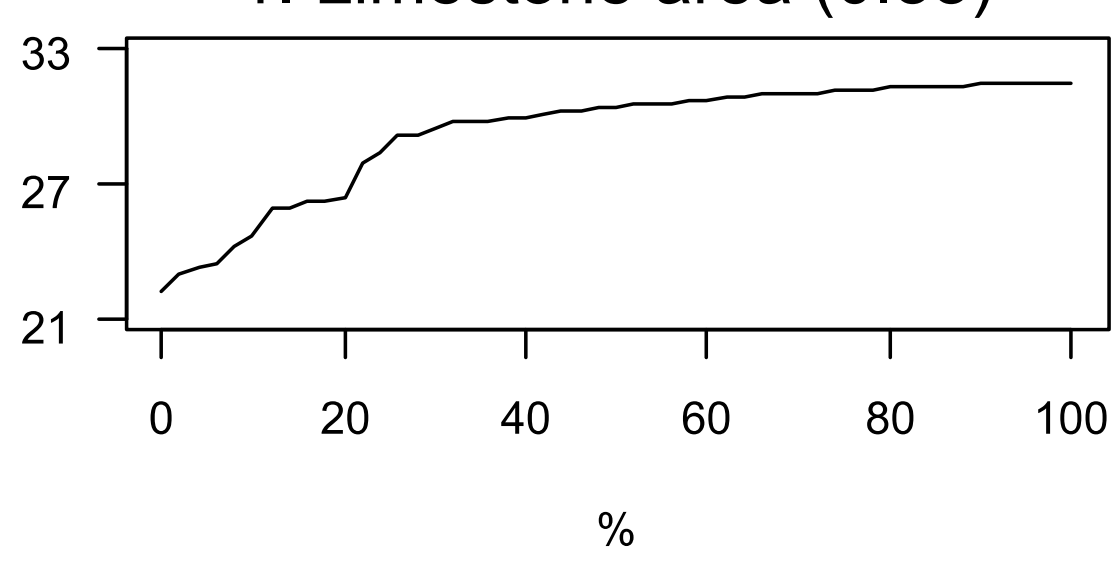

1. Annual AET (0.95)

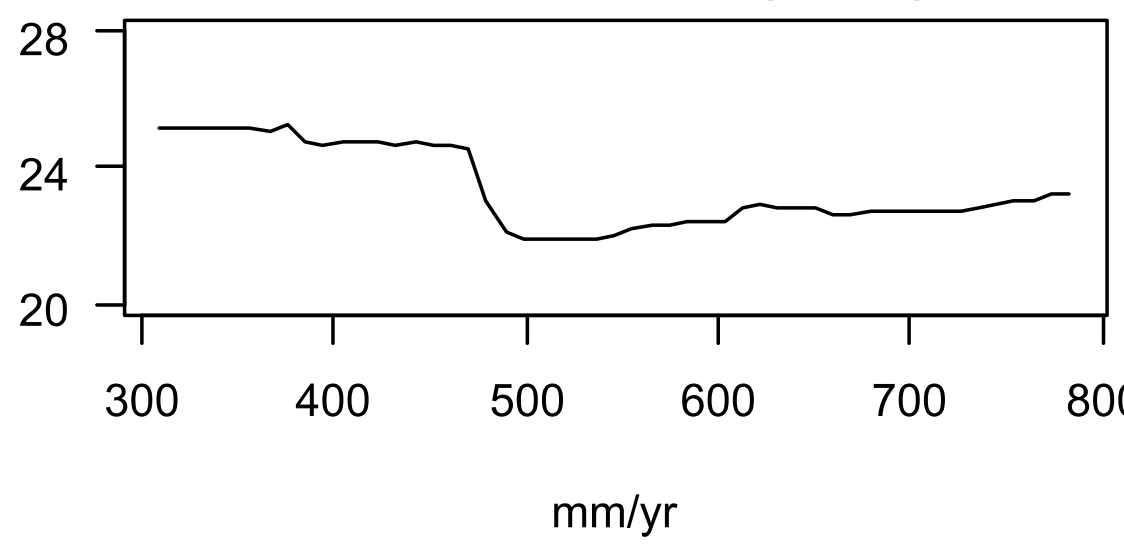

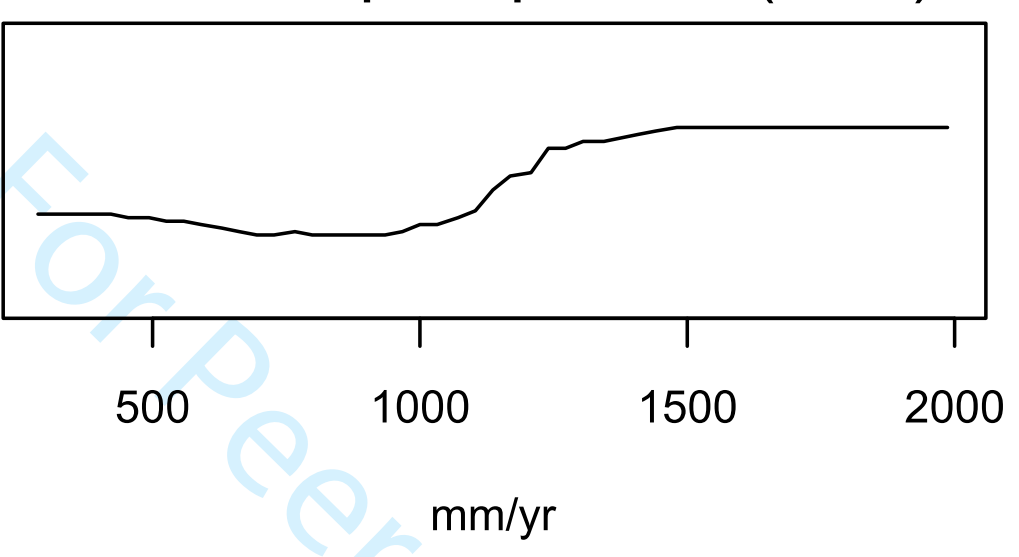

(c) Coniferous

2. Terrain ruggedness $(0.63)$

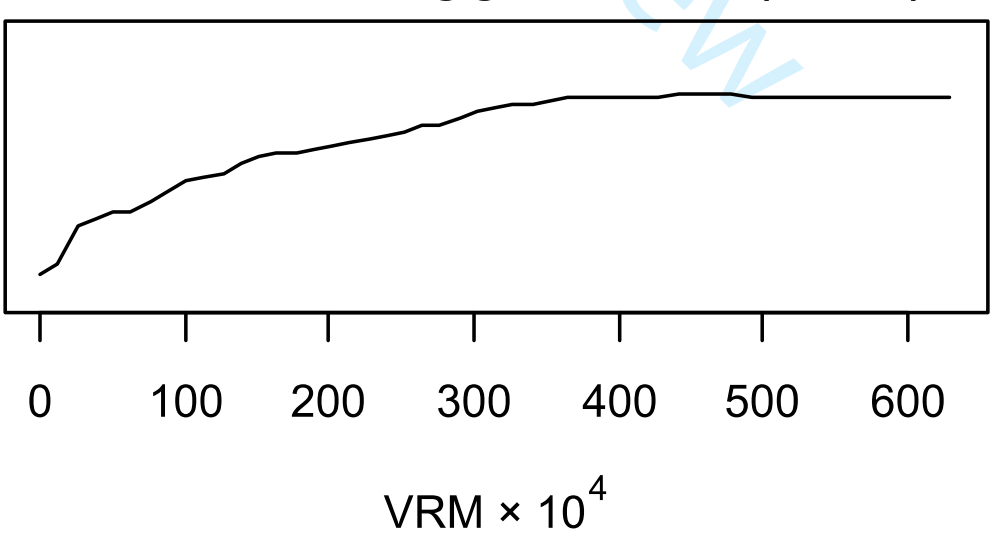

(d) Sclerophyllous

2. Annual precipitation (0.87)

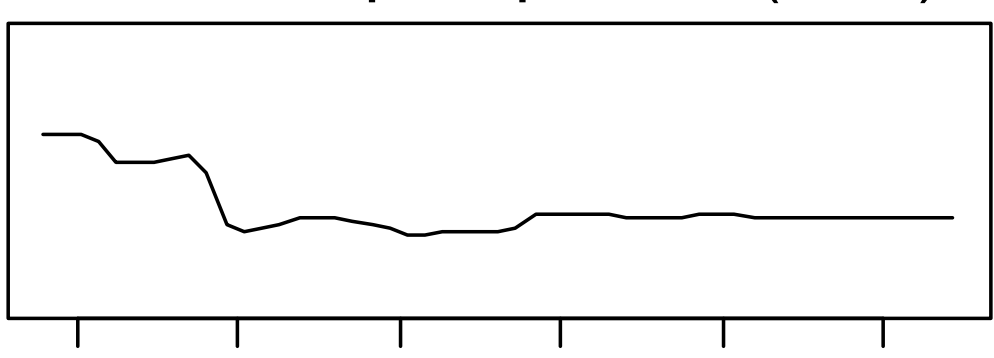

$\begin{array}{lllllll}800 & 400 & 600 & 800 & 1000 & 1200 & 1400\end{array}$
3. Temperature seasonality $(0.63)$

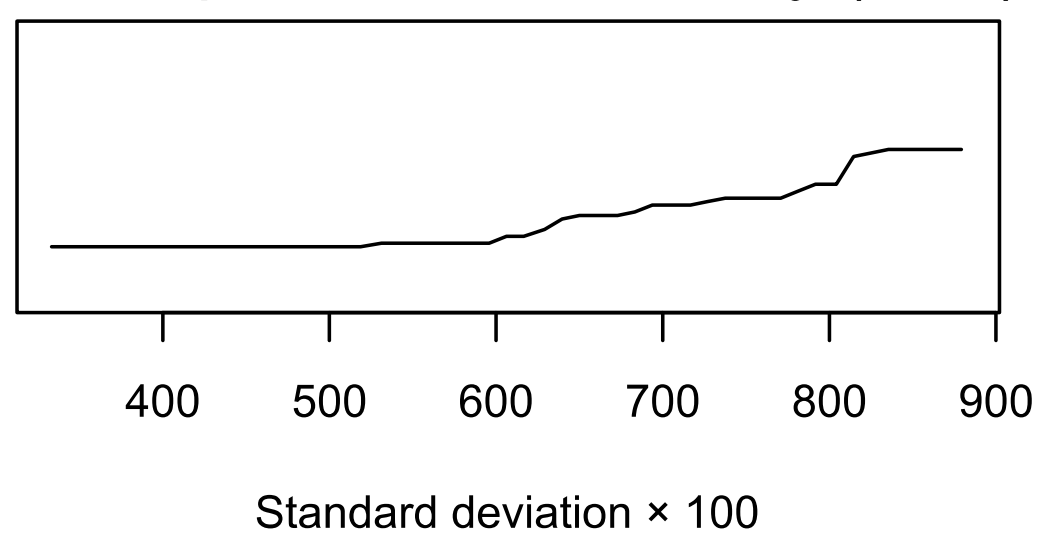

3. Annual PET (0.86)

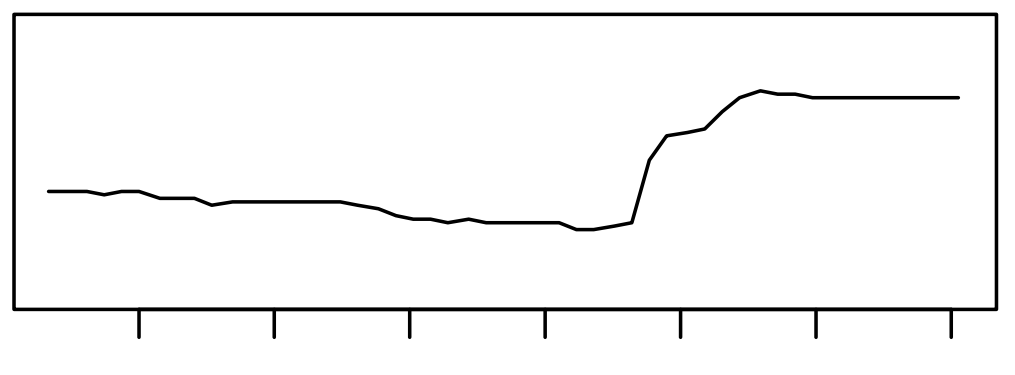

$\begin{array}{lllllll}700 & 800 & 900 & 1000 & 1100 & 1200 & 1300\end{array}$ 
09-Apr-2019

Dear Dr. Večeřa,

Reference Number: JBI-18-0562.R1

Title: Alpha diversity of vascular plants in European forests

We have designated the above paper as on track for acceptance subject to final corrections being carried out. Specifically we require that the data be made available so that the analyses can be repeated. The handling editor, Holger Kreft, provides more specific s on what is required.

Please see below and see any attached file(s) for any editorial or reviewer comments that require your attention.

We look forward to receiving your revised manuscript within 14 days.

Thank you again for submitting to the 'Journal of Biogeography'. We look forward to receiving the revised version of your paper.

Yours sincerely,

Steven Higgins

Chief Editor, Journal of Biogeography

\section{EDITOR'S COMMENTS TO AUTHOR}

Editor: Kreft, Holger

Comments to the Author:

Dear authors,

thanks for your careful revision. Your manuscript has now been seen by the two original referees and they are generally very happy how you dealt with the issues raised and I agree with them.

There is one thing that you might want to consider that relates to Data accessibility. It is great that you are planning to make available the modeled richness maps. However, I also strongly urge you to consider publishing the full data frame that was used for the analyses. Otherwise, I am afraid that your analyses will not be replicable.

Best regards,

Holger Kreft

Prof. Holger Kreft 
Dear editors,

We are glad for the decision to accept our study.

Regarding your recommendation to publish full data that we used, it is not possible to make the dataset freely available due to the European Vegetation Archive (EVA) policy. However, the dataset we used is stored in EVA and can be obtained upon request. I have specified this issue in the Data accessibility statement.

With best wishes,

Martin Večeřa

On behalf of all the co-authors

\section{REVIEWER COMMENTS TO AUTHOR}

Referee: 1

Comments to the Author

Review Journal of Biogeography - JBI-18-0562.R1

Alpha-diversity of vascular plants in European forests

This is the revised version of a manuscript which I reviewed already in the original version. In general, most of the remarks and comments of the reviewers and by the editor have been considered in this revised version, mainly in focusing on mapping and understanding the drivers of species richness. I am not completely satisfied considering the management or naturalness aspect on the selection within the datasets, especially by the "phytosociological" or "natural forest habitat" criteria of vegetation-plot sampling: maps for coniferous forests e.g. in Belgium, the Netherlands or Czech Republic present spatial diversity patterns within areas which belongs not to landscapes where coniferous forests will be close-to-nature.

Nevertheless, I recommend publishing the paper in this revised version.

Thank you for your comments and suggestions. We are aware of the mentioned issues, they are discussed in the manuscript. We consider them to be a potential subject of improvement for future maps of alpha diversity in European forests, once the data on non-native occurrence of coniferous as well as other forest types are available at the pan-European extent.

Referee: 2

Comments to the Author 
Dear authors,

Thank you for careful revision and detailed replies. I do appreciate the progress you have done with the paper. Correlation plots are very helpful to understand the data used in the models. I still think that percentages of different land-covers within a single model is not the best idea but I agree that this does not change your results much. I am very happy to see the uncertainty maps.

Thank you for your comments and suggestions. Regarding the land-cover proportions, we will think also about different solutions for similar projects in future. 